
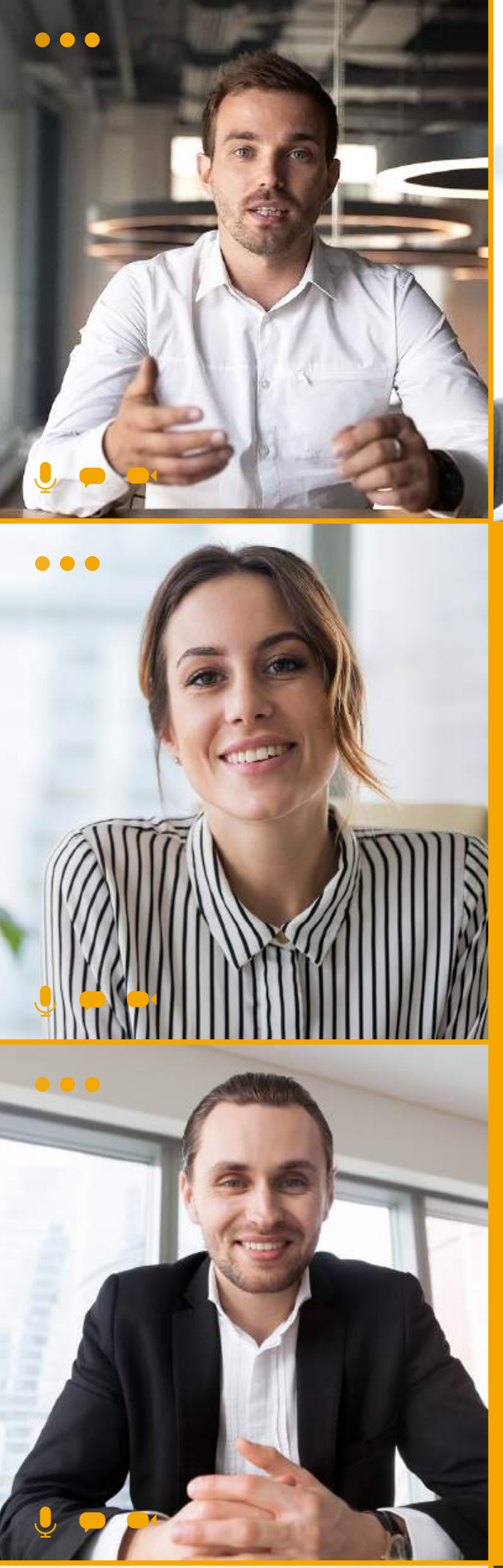

АНАЛИТИЧЕСКИЙ СПЕЦПРОЕКТ

\title{
HOBAЯ НОРМАЛЬНОСТЬ
}

Образ жизни, рынки, инфраструктура и коммуникации после пандемии
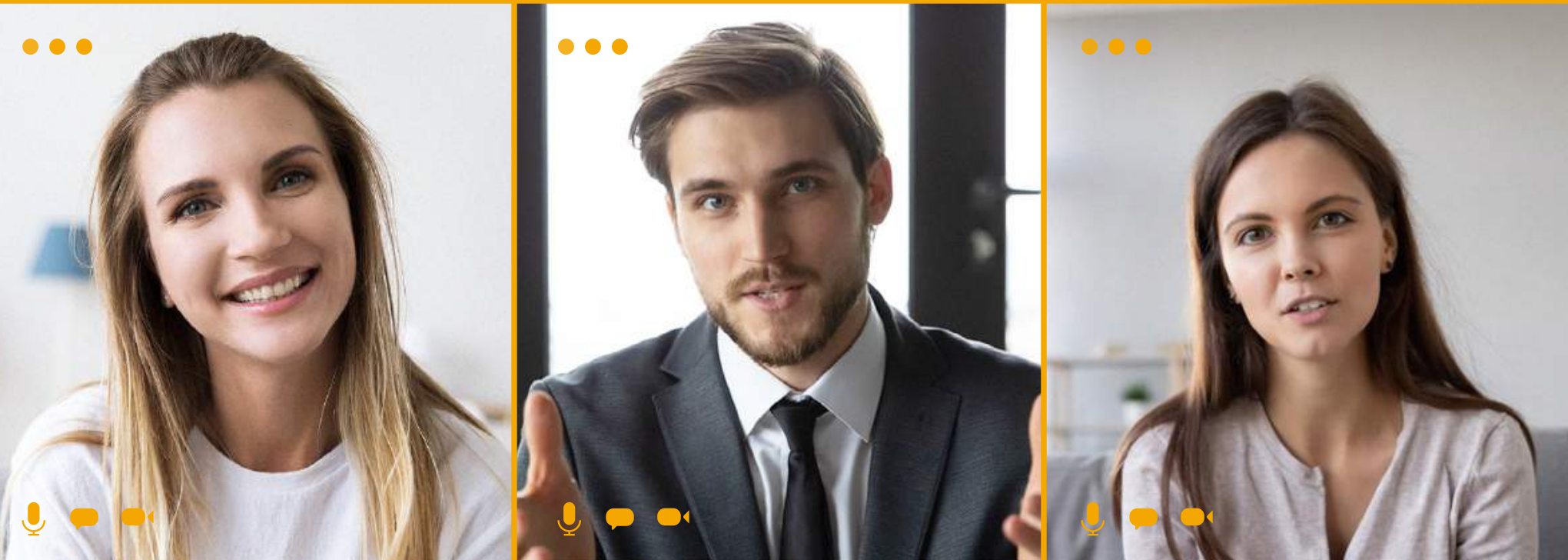


\section{HOBAЯ \\ НОРМАЛЬНОСТЬ}

Образ жизни, рынки, инфраструктура и коммуникации после пандемии 
Новая нормальность. Образ жизни, рынки, инфраструктура и коммуникации после пандемии / Аналитический центр НАФИ, авторы: Т. А. Аймалетдинов, И. А. Гильдебрандт, Е. Н. Никишова, Д. С.Рассадина. М.: Издательство НАФИ, 2020. - 73 с.

() Текст Аймалетдинов Т. А., Гильдебрандт И. А., Никишова Е. Н., Рассадина Д. С., 2020

(с) Оформление Басевич Д. В., 2020

(с) Издательство НАФИ, 2020 
ВВЕДЕНИЕ

МЕТОДОЛОГИЯ

КАК ПАНДЕМИЯ КОРОНАВИРУСА ОТРАЗИЛАСЬ В ОБЩЕСТВЕННОМ СОЗНАНИИ?

8

НОВАЯ РЕАЛЬНОСТЬ: ГРОМКИЕ СЛОВА ИЛИ РЕАЛЬНЫЕ ИЗМЕНЕНИЯ

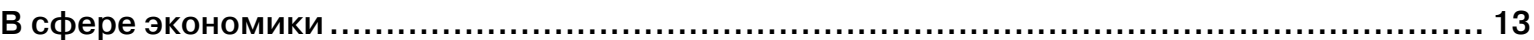

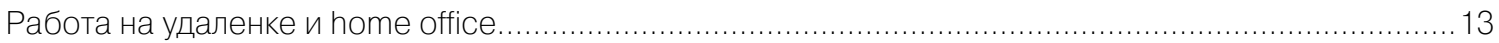

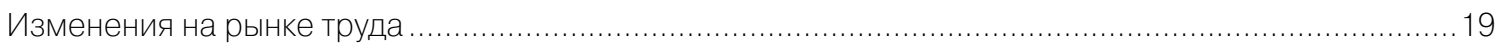

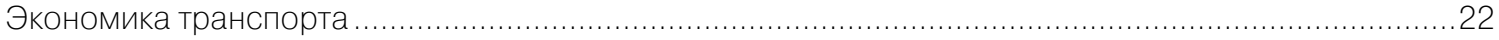

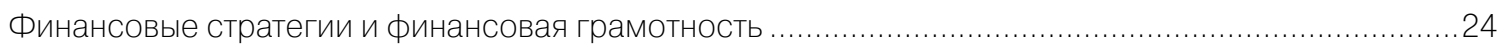

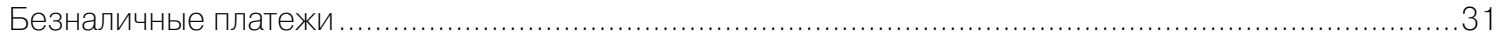

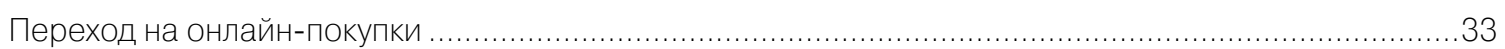

Изменение поведения покупателей в офлайн: новые вызовы и возможности для ритейлеров ........34

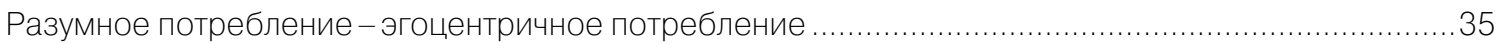

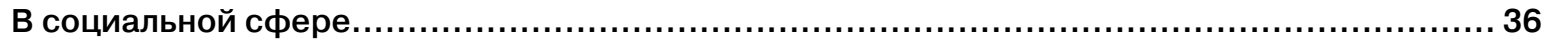

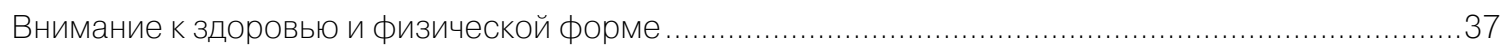

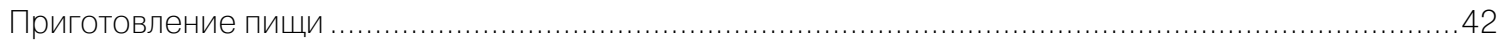

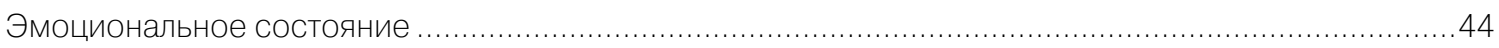

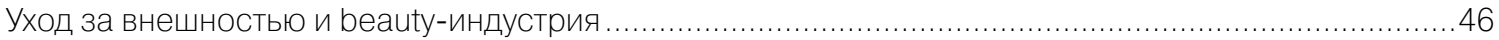

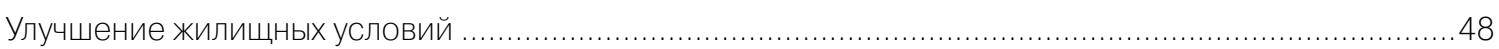

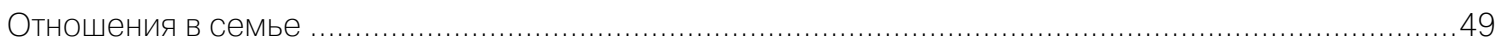

Общественная солидарность, взаимопомощь и волонтерство ...............................................51

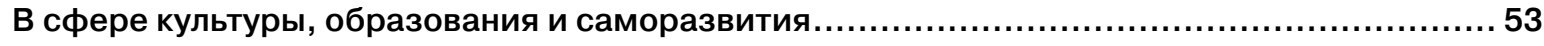

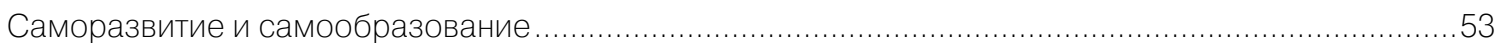

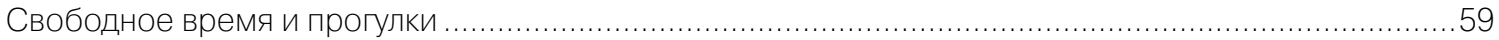

Доверие к СМИ и медиапотребление ....................................................................6 60

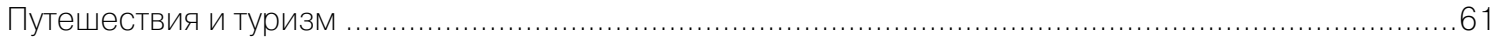

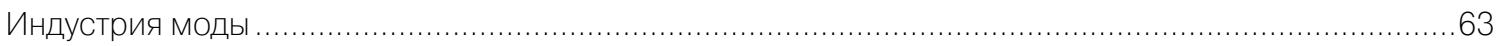

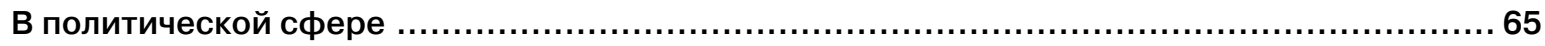

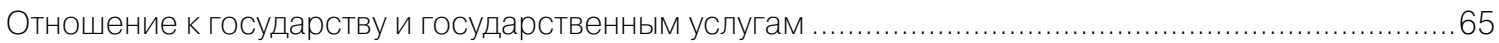

Демократизация и развитие гражданского общества .......................................................6 
E_HАФИ
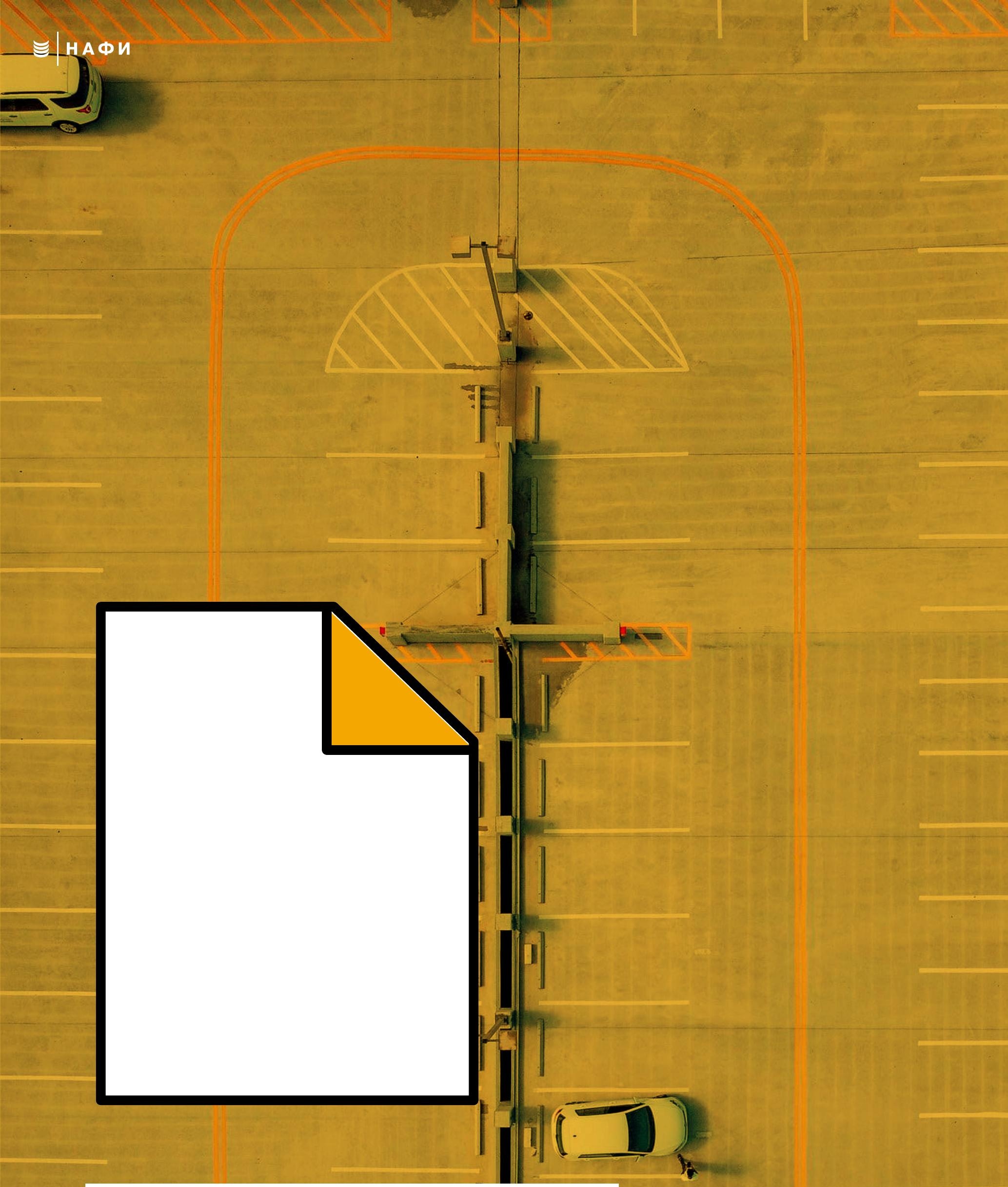

| ВВЕДЕНИЕ

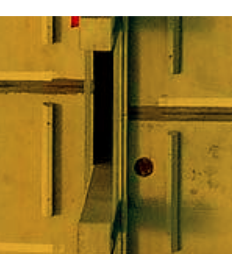




\section{Термин «новая нормальность» («New Normal») получил широкое распространение после финансового кризиса 2007-2008 годов и ранее в основном использовался} для описания социально-экономических последствий глобальной рецессии.

Сегодня «новой нормальностью» определяют не столько экономические, сколько социальные последствия глобальной пандемии COVID-19-то есть последствия в разных аспектах жизнедеятельности человека, подразумевая, что то, что совсем недавно было ненормальным, становится обычным явлением.

\section{Большую общественную огласку в России этот} термин получил в апреле 2020 года после его использования в телевизионном интервью главой Роспотребнадзора Анной Поповой, которая заявила: «Нам надо готовиться, и это совершенно очевидно уже, что у нас теперь наступает новая нормальность-мы должны будем поменять свои привычки».

Тем не менее, термин «новая нормальность» вызывает у некоторых социологов неприятие - они не считают, что жизнь претерпит кардинальные изменения.

«В большей степени все будет возвращаться в обратное состояние. Если потихоньку снимут ограничения, то вряд ли кто-то будет соблюдать социальную дистанцию в общественном транспорте. Я уверен, что не прекратятся наши дружеские посиделки и выезды на природу. Возможно, все будут пользоваться санитайзерами, но повлияет ли это на «новую реальность», вот в чем вопрос» [Завцентром анализа социальных программ и рисков Института социальной политики НИУ ВШЭ С. Смирнов] ${ }^{1}$

В то же время едва ли найдется человек, который не ожидает изменений образа жизни людей после пандемии коронавируса. Скорее, речь идет о том, что некоторые изменения будет сложно распознать: когда к этой «новой нормальности» люди привыкнут, им будет казаться, что так было всегда.

В связи с нетипичностью ситуации, экономические прогнозы сегодня делаются специалистами крайне аккуратно, и это логично: изменения будут носить разнонаправленный, зачастую стихийный характер. Сегодня чаще говорят о перспективах, шансах и направлениях развития, чтобы на основе уже существующих тенденций описать возможные сценарии будущего, поддержать позитивные тренды и противостоять негативным.

Настоящий документ описывает уже проявляющиеся тенденции на основе данных самых последних социологических исследований, а также экспертные прогнозы специалистов Аналитического центра НАФИ, построенные на основе этих исследований. Прогнозы описывают изменения окружающей реальности, в том числе потребительских рынков, отношений в семье и референтных группах, в культурных практиках и взаимоотношениях человека с государством. 

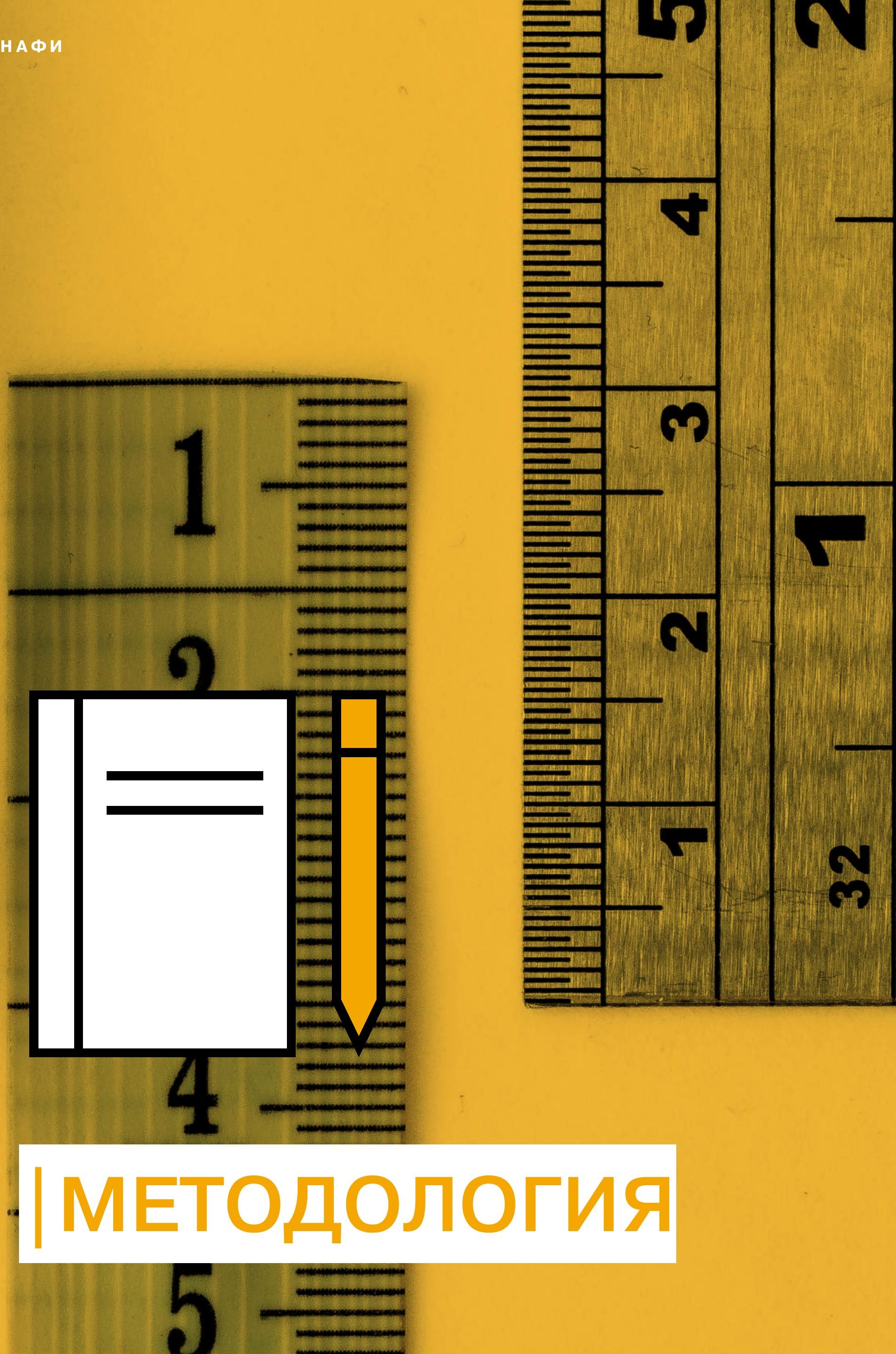


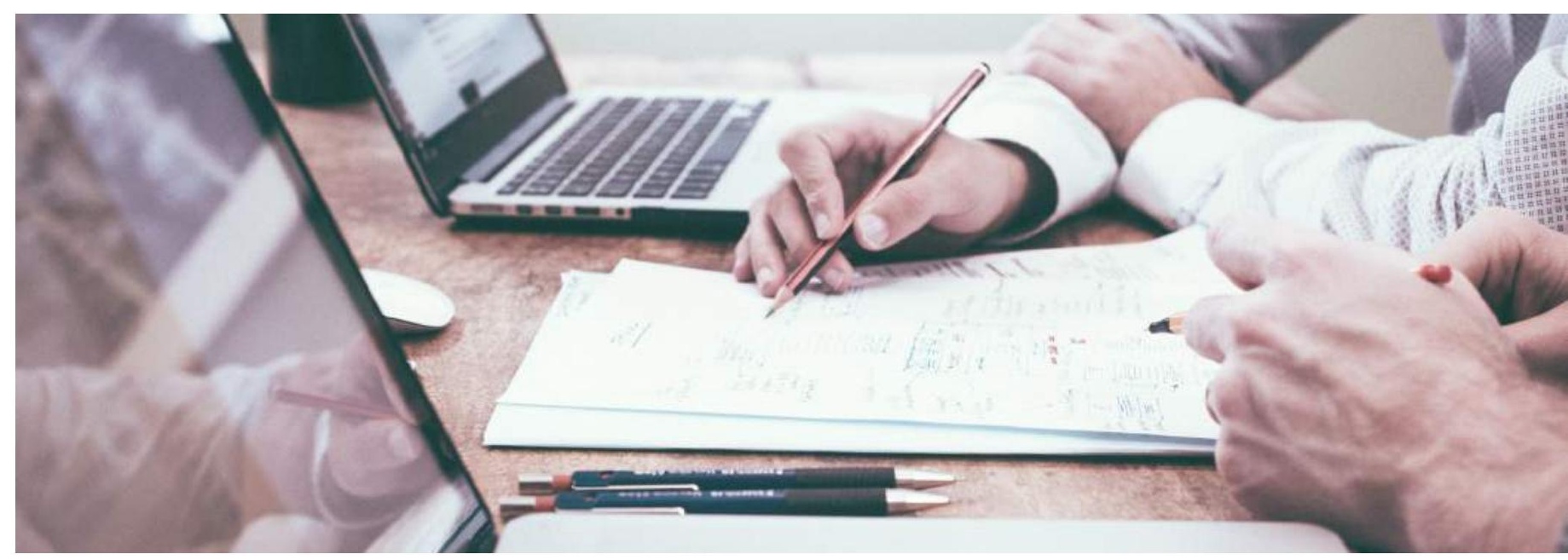

Первичные данные, приведенные в настоящей брошюре, получены из следующих источников:

1. Ежемесячные репрезентативные всероссийские опросы Аналитического центра НАФИ:

- проводимые по национальной репрезентативной выборке в размере 2000 человек. Опрос проводится не менее чем в 46 регионах Российской Федерации, в 152 населенных пунктах. Статистическая погрешность данных составляет не более 2,7\%.;

- проводимые по выборке опросы руководящих сотрудников предприятий микро-, малого и среднего бизнеса в размере 500 человек. Опрос проводится не менее чем в восьми федеральных округах РФ. Статистическая погрешность данных составляет не более 4,4\%. Опросы проводятся в форме телефонного интервью (САTI).

2. Серия глубинных интервью с жителями России, Германии, Австрии, Швейцарии, США и других стран. Опрошенные представляют разные социально-демографические и профессиональные группы. Фрагменты интервью представлены в брошюре в виде цитат.

3. Вторичный анализ статистических данных и данных социологических исследований, проведенных коллегами из исследовательской отрасли-компаниями GfK, Ipsos, Всероссийским центром изучения общественного мнения и др.

4. Данные анализа СМИ и социальных сетей получены из базы данных Interfax-SCAN (https://scaninterfax.ru).

Если в тематическом обзоре использованы данные из других источников, ссылка на источник данных указана в тексте, под таблицей или диаграммой, либо в форме постраничной ссылки.
Все данные, за исключением индексов, представлены в процентах от количества опрошенных или количества описываемой группы. Сумма всех ответов может быть больше 100\% в тех случаях, когда предусмотрена возможность выбора нескольких вариантов ответа. Все представленные взаимосвязи между переменными протестированы на статистическую значимость, которая установлена на уровне не ниже $p=0,05$.

Дополнительная информация - данные в форме таблиц и диаграмм - доступна на сайте Аналитического центра НАФИ-https://nafi.ru.
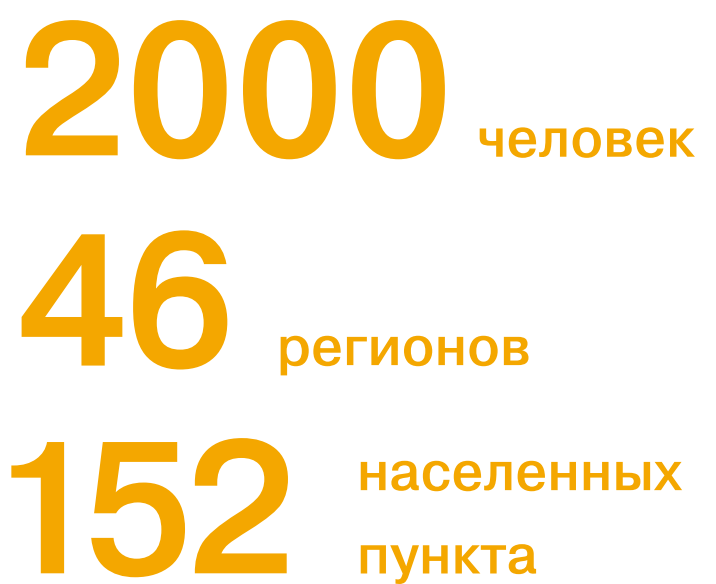

населенных

пункта 
(5) HAक of 0 \&

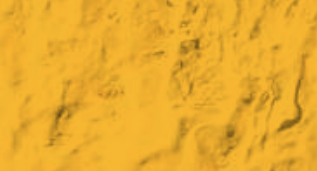
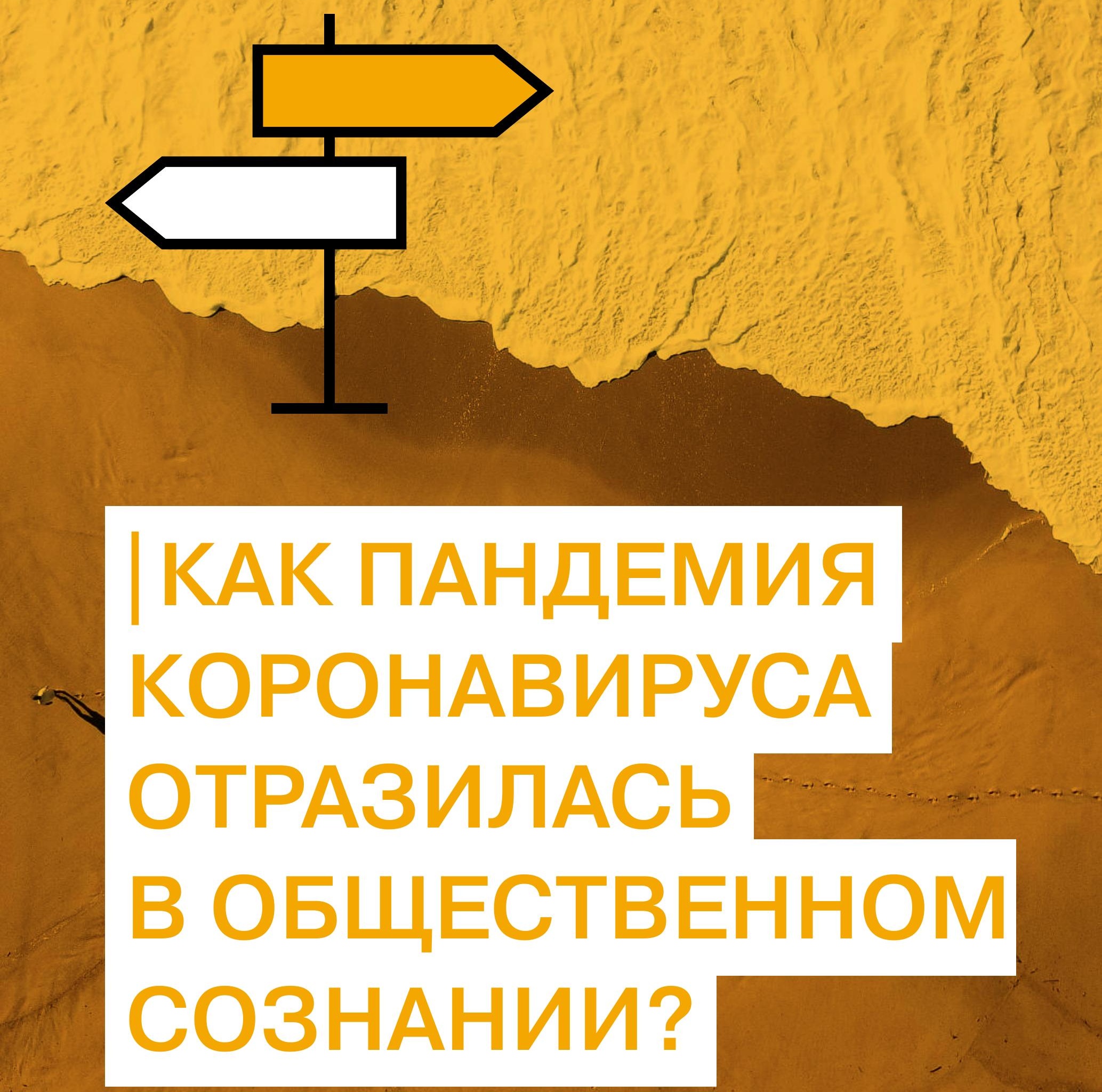


\title{
«Человек должен иметь возможность отнести себя
}

\author{
к какой-то системе, которая бы направляла его жизнь \\ и придавала ей смысл; в противном случае его переполняют \\ сомнения, которые в конечном счете парализуют \\ его способности действовать, а значит, и жить»
}

Эрих Фромм. «Бегство от свободы», 1941

Ситуация с эпидемией коронавируса - экстраординарная. В жизни многих людей вызванные пандемией перемены не случались никогда - ни по масштабу, ни по характеру.

В социологическом сообществе происходящее было названо «пандемией страха». За несколько месяцев миллионы людей осознали или, как минимум, ощутили внутренний страх потери смысла жизни. Почти каждый задавался вопросом о том, что он собой представляет, какова его роль в семье, на работе, в обществе и «куда податься», если коронавирус кардинально изменит традиционный уклад жизни.

Общественное сознание переосмыслило ценность реальных отношений между людьми, роль государства и отдельных социальных институтов в жизни человека. У россиян проснулось правосознание, внезапно повысилась чувствительность к подмене понятий (самоизоляция и изоляция).

Главное, что произошло внезапное «схлопывание перспектив», и именно это явным образом разделило людей на тех, кто готов действовать, и тех, кто решил ждать. Что отличает их друг от друга и как быстро они адаптируются к новым правилам жизни?

«Для меня самоизоляция из-за пандемии - это период, который предоставил уникальную возможность оценить свои внутренние ресурсы, задуматься, кто ты и что еще умеешь, помимо того, чем занимался раньше» [спортивный тренер, женщина, 32 года, Москва]

«С этого момента началось повышение самосознания. Люди посмотрели, кто они, что собой представляют. Человек на примере своей собственной жизни приходит к пониманию, что он сам должен выйти из этой ситуации» [руководитель компании, женщина, 34 года, Уфа]
На самоизоляции люди по-новому взглянули на гуманитарную роль цифровизации - на возможности, которые она открывает в работе, учебе, досуге, и угрозы, к которым она может привести, если будет происходить бесконтрольно. Фактически, пандемия разделила людей не просто на «готовых действовать» и «готовых ждать», а на особые психотипы по отношению к цифровизации - на технооптимистов и технопессимистов, на тех, кто готов к изменениям, и тех, кто к ним не готов, на «общество граждан» и «общество подданных».

«Мы находимся на этапе создания нового общества, с развитием новых бизнесов на стыке традиционных областей и информационных технологий. Это прекрасное время, время перемен. Оно позволило нам экспериментировать, не бояться и чувствовать себя открытыми, позволило понять, что у нас нет внутренних границ. Это жизнь, она меняется, и ты должен адаптироваться, чтобы выжать максимум из новых условий» [специалист в сфере digital-pr, женщина, 33 года, Женева]

Первых отличает высокая чувствительность к разнообразию, вторых-тяга к традициям, страх войти в открытую дверь, в новую цифровую эпоху, бесконечное ожидание варваров и нацеленность «на готовые рецепты». В период пандемии первые почувствовали себя в своей атмосфере и серьезных изменений не заметили, вторые-столкнулись с тем, что готовые рецепты не работают: нужно или меняться, или до конца сопротивляться переходу к новой более комфортной цифровой реальности.

«В одну реку дважды войти нельзя, так и в этот мир дважды войти нельзя. Я думаю, что к той жизни, к которой мы все привыкли, будет совсем другое отношение. Что-то должно измениться - особенно в жизни простых людей» [руководитель строительной компании, мужчина, 55 лет, Москва] 
છ Н А Ф И
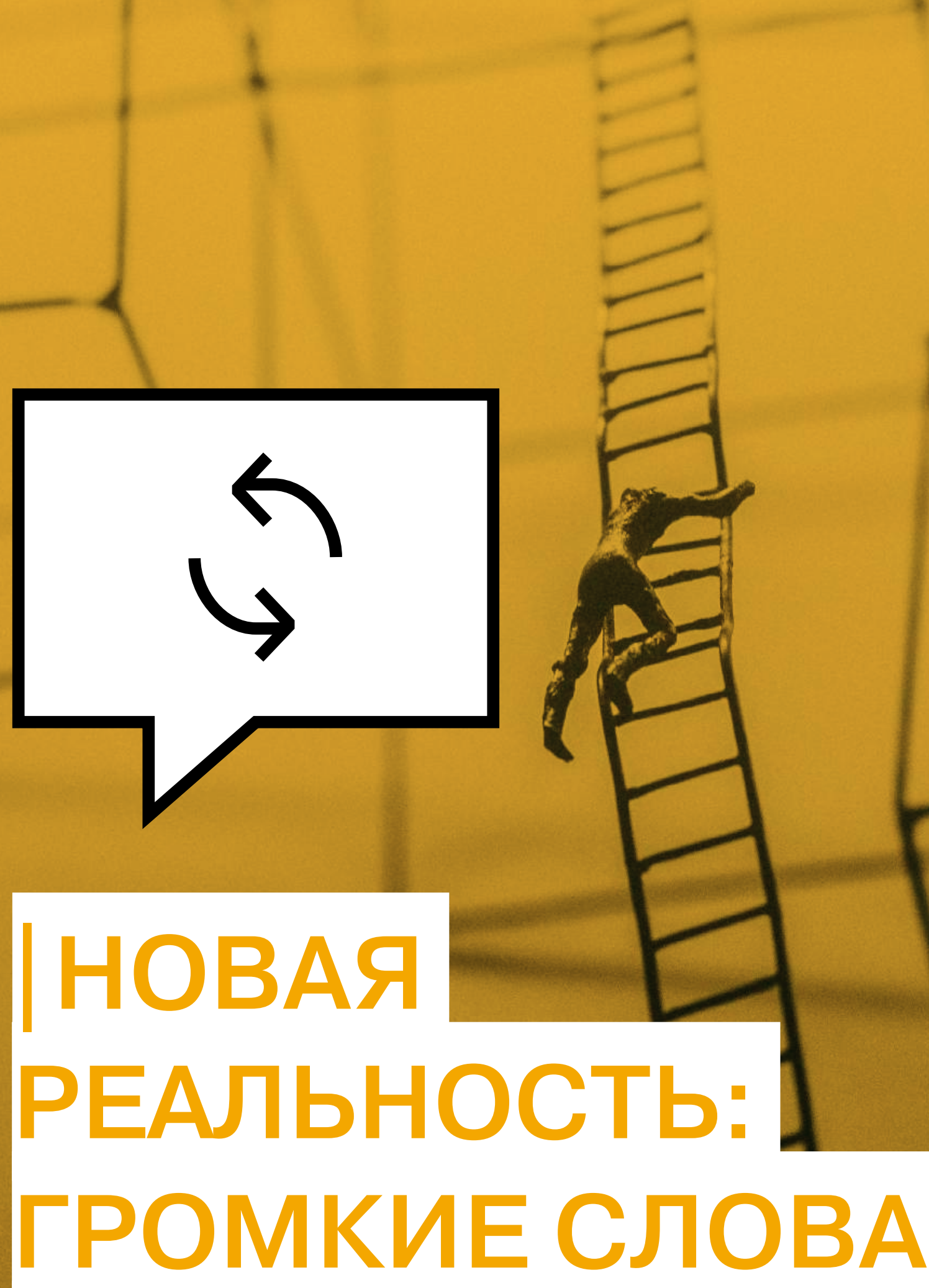

ИЛИ РЕАЛЬНЫЕ

ИЗМЕНЕНИЯ 


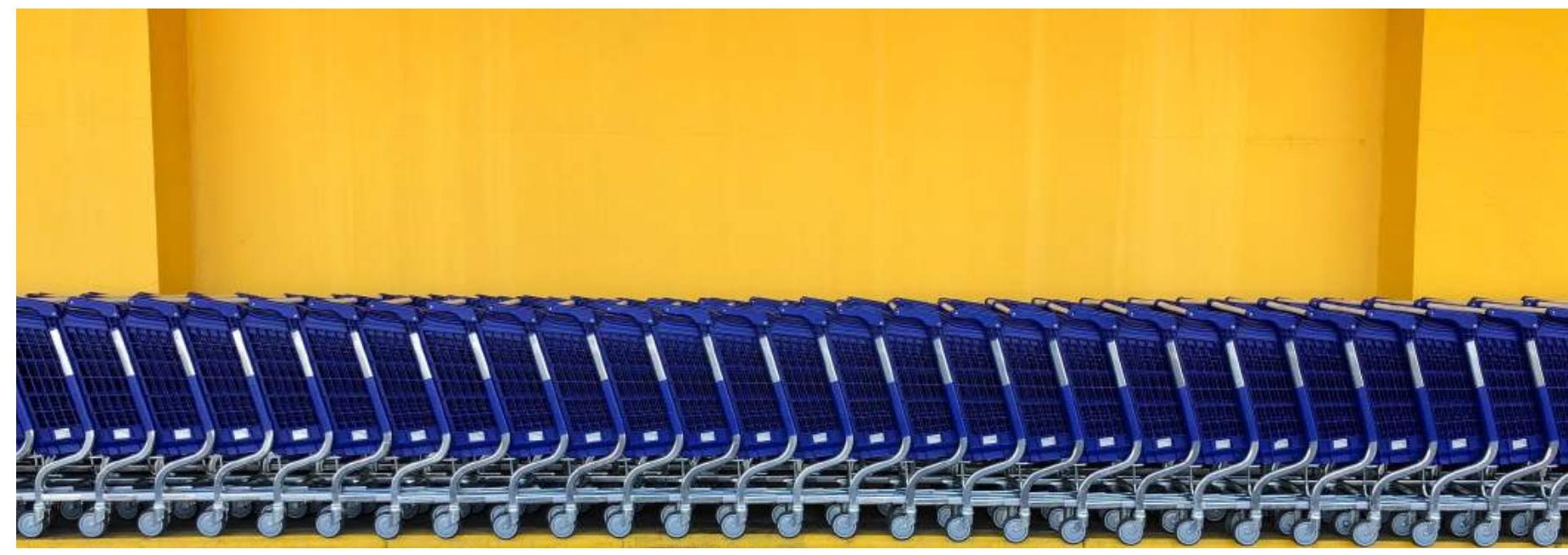

Сегодня одни люди говорят, что после эпидемии все вернется на свои места, другие - что мир уже не будет прежним: люди и их образ жизни изменятся.

В любом случае, в ближайшее время нам предстоит наблюдать период «ремиссии» - сплетение миллионов компенсаторных эффектов самоизоляции.

Главное и, пожалуй, самое очевидное изменение носит экономический характер - общество возвращается к более бедному образу жизни, начинает формироваться новая экономика - более цифровая, более устойчивая и более экономная. Новая экономика начинает формировать и новое общество - поляризованное по критерию адаптивности к изменениям, с переосмысленными ценностями жизни. Общество, разделенное на тех, кто не вернется к прежней жизни, увидев новые возможности, и тех, кто уже через несколько месяцев продолжит жизнь старую, с прежними принципами и установками.

«Жизнь изменится у активных и думающих людей, которые на самоизоляции не сидели и не щелкали пультом от телевизора, а открыли в себе что-то новое и как-то подстроились. Выиграет в итоге человек, который понял, что в жизни у него не одна-единственная дорога» [спортивный тренер, женщина, 32 года, Москва]

Серьезные кризисы всегда приводят к переоценке ценностей, пересмотру приоритетов, особенно в среде молодых людей. Коронакризис не стал исключением - он затронул все сферы жизнедеятельности общества и личности: на глазах формируется новая система социальных коммуникаций, новое потребительское поведение, новый взгляд на роль государства. Фактически, посткризисное изменение общественного сознания начинает конструировать новую реальность. Коронакризис показал, насколько важным для человека оказался офлайн, когда его стало меньше. Оказалось еще более очевидным, что общество и экономика неминуемо вступают в эру цифровизации, а стремительное проявление кризисных процессов планетарного масштаба в демографии, ресурсном, экологическом обеспечении жизни людей обусловлено, в первую очередь, резким отставанием темпов социального и культурно-духовного развития человечества от научно-технического прогресса.

Нами разделяется мнение современных социологов о том, что именно свободный, творческий человек, яркая индивидуальность, раскрывающаяся в разнообразных видах деятельности и в общении, постепенно должна становиться содержанием и высшей целью новой модели общества². В настоящей брошюре специалисты Аналитического центра НАФИ попытались найти и показать до недавних пор слабые, но проявленные пандемией коронавируса тенденции в эволюции образа жизни людей и их социально-экономические последствия. 


\section{Є Н АФи}

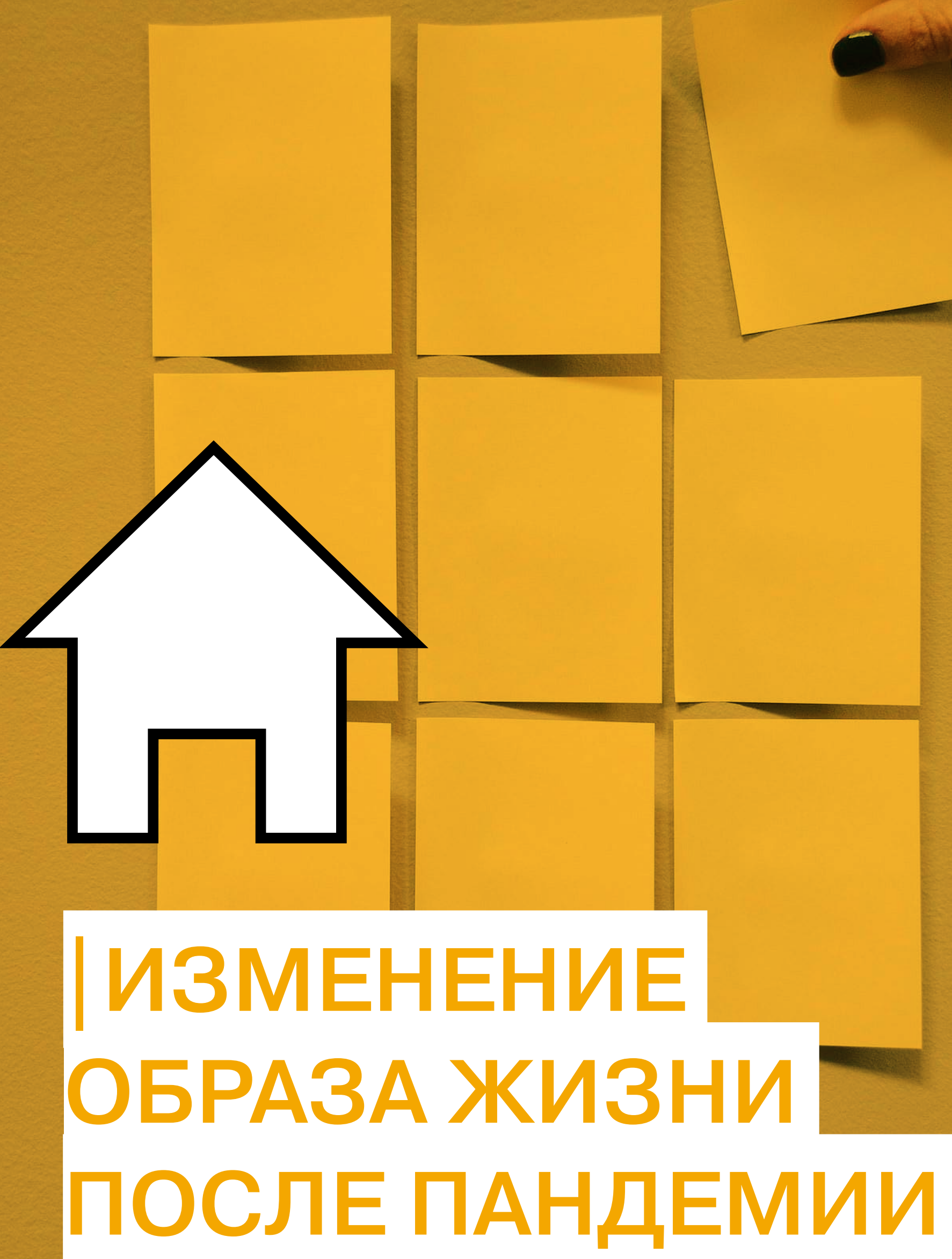




\section{В СФЕРЕ ЭКОНОМИКИ}

\section{РАБОТА НА УДАЛЕНКЕ И НОМЕ ОFFICE}

$\begin{array}{lll}\text { Гипотеза } & \text { Краткосрочный прогноз (1-3 года) } & \text { Среднесрочный прогноз (5-7 лет) } \\ \text { Удаленная } & \text { В ближайшие три года удаленный } & \text { В перспективе 5-7 лет будет происходить более } \\ \text { занятость станет } & \text { формат занятости будет } & \text { явное вытеснение за пределы офиса рутинных задач, } \\ \text { новым стандартом } & \text { распространяться медленно, } & \text { выполнение которых возможно дистанционно. Этому } \\ \text { современных компаний } & \text { докризисными темпами } & \text { будут способствовать развивающиеся средства } \\ & & \text { контроля за выполнением распределенных задач и смена } \\ & & \text { общественного мнения о статусе надомной работы. }\end{array}$

За год до пандемии коронавируса работающие дистанционно сотрудники были в штате каждой четвертой российской компании, причем удаленный формат работы был более характерен для микрои малого бизнеса, а также для крупных международных компаний (в основном из сегмента ИТ). Среди компаний, удаленная работа в которых не практиковалась, возможность перевода части сотрудников на такой формат занятости рассматривалась очень редко (не более 6\% предприятий от числа тех, где удаленные сотрудники отсутствовали) $)^{3}$.

\section{Доля российских}

\section{предприятий, в которых есть} сотрудники, работающие

\section{дистанционно}

в \% от общего количества компаний с разной численностью сотрудников

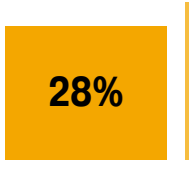

Все предприятия

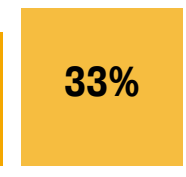

1-15 человек

\section{$20 \%$}

16-100 человек

\section{$13 \%$}

Свыше
Источник: всероссийский опрос руководителей МСБ, n=500, НАФИ, март 2019 года
За исключением отдельных стран и отраслей во всем мире переход на дистанционную занятость происходил довольно медленно. Барьеры этому процессу носили как объективный (физическая невозможность выполнения отдельных видов работы, правовая незащищенность и пр.), так и субъективный характер (сложность контроля качества работы и загруженности сотрудников, опасения в снижении производительности труда и др.). В общественном сознании такого рода занятость ассоциировалась с нестабильностью, неформальными трудовыми отношениями, творческими профессиями, подработками.

Сейчас в крупных городах в сегменте офисных сотрудников удаленная работа перестает быть чем-то маргинальным или несерьезным. Отдельные исследования показывают, что россияне ожидают распространение практики удаленной работы во многих компаниях, а значит, и сами постепенно будут готовы к переходу на такую форму занятости 4 . Главное слово - «постепенно». Работники со временем должны подготовиться к удаленному формату занятости и морально, и профессионально. В первом случае, мы согласны с А. Ослоном, который объясняет это следующим образом:

«Есть такое социологическое понятие «жизненные миры»-мир профессиональный, спорта, хобби, любви и так далее. Они очень разные - соприкасаются, но не смешиваются. Пандемия смешала два очень важных мира: мир дома и мир работы, и это 
тяжелая нагрузка на психику. Поэтому многие просто побегут на работу» 5 .

Если же говорить о профессиональной готовности к удаленной работе, то речь здесь, главным образом, идет о двух моментах - технических навыках работы вне офиса (цифровой грамотности) и навыках самодисциплины и самоконтроля. Рост цифровой грамотности, вызванный пандемией, очевиден. За период карантина многие успешно освоили сервисы видеоконференций, групповые рабочие чаты и системы проектного менеджмента, облачные сервисы и многое другое. Все это, на наш взгляд, станет серьезной предпосылкой для развития дополнительной занятости (фриланс, подработка, удаленное репетиторство), к которой многие прибегут в попытках восстановить прежний уровень дохода.

Однако такого рода подработки, рассеивание внимания на разноплановые задачи, наряду с отсутствием рабочей атмосферы дома, будут мешать требуемому самоконтролю и самодисциплине, а значит, будут снижать производительность труда на основной работе. В итоге ключом к эффективности удаленки станет высокооплачиваемый дистанционный труд, к которому пока не готов работодатель. Поэтому, если коронакризис вконец не разрушит конкретный бизнес, арендодатели офисных зданий могут не волноваться - спрос вернется, и в ближайшей перспективе удаленная работа не заменит офисный формат. Это подтверждается результатами опроса бизнеса, проведенного в период пандемии.

Предприниматели в большинстве случаев не рассматривают возможность сохранения дистанционной занятости сотрудников после окончания пандемии. Только 20\% предприятий готовы сохранять режим удаленной работы для части своих сотрудников, 7\% - для всех сотрудников ${ }^{6}$
«Насколько вероятно, что режим удаленной работы будет сохранен

в компании для сотрудников

\section{и после окончания режима}

самоизоляции?»

в \% от всех опрошенных предпринимателей, которые перевели сотрудников на дистанционный формат

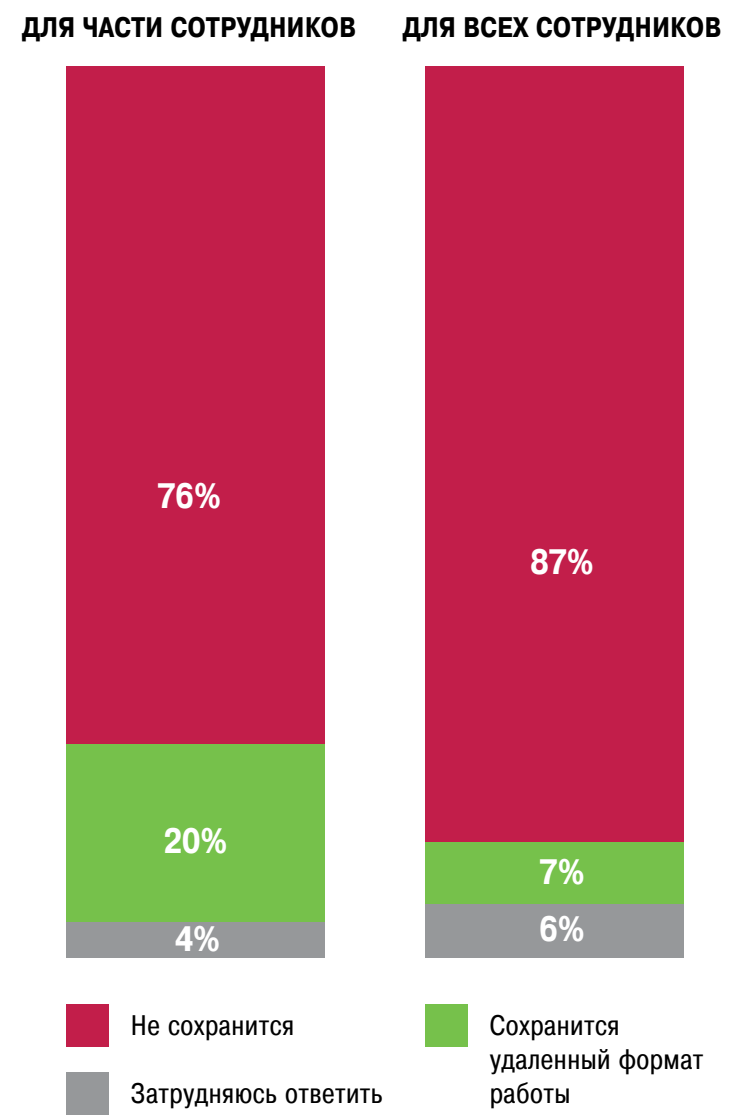

Источник: всероссийский опрос руководителей МСБ, n=1500, НАФИ, апрель 2020 года

Интервью с А. Ослоном «Сейчас люди плохо понимают, что и как будет завтра» / Известия, 28.05.2020 / Доступно по ссылке: https://iz.ru/1016001/maksim-khodykin/seichasliudi-plokho-ponimaiut-chto-i-kak-budet-zavtra

Спецпроект НАФИ «Влияние коронавируса на бизнес». Часть 2 «Человеческий капитал: сокращения персонала и удаленный формат работы» / Доступно по ссылке: https://nafi.ru/projects/predprinimatelstvo/rossiyskiybiznes-i-koronavirus-vtoraya-chast-chelovecheskiy-kapitalsokrashcheniya-personala-i-udal/ 
В то же время мы разделяем мнение социолога, первого замруководителя Департамента труда и социальной защиты населения Москвы А. Александровой о том, что работа в офлайнрежиме станет привилегированной: начальство будет делить сотрудников на тех, кто будет трудиться в офисе, и тех, в чьем физическом присутствии на работе не нуждаются:

«Сформируется своеобразная «элита» работающих в офисе штатников, занимающихся постановкой задач. Они будут «ядром кометы», а хвост составят загруженные работой удаленщики, которых будут постоянно испытывать на прочность и организованность максимально жесткими дедлайнами» ${ }^{7}$.

На наш взгляд, разделение сотрудников на работающих в офисном и удаленном форматах будет происходить постепенно. Серьезным препятствием продолжит оставаться несформированное общественное мнение по этому вопросу, а также недостаточная правовая база для работы в удаленном формате.

«Угроза пандемии COVID-19 и вынужденная самоизоляция граждан стали причиной перехода многих россиян на дистанционный формат работы. При этом работники и работодатели сталкиваются с проблемой оформления соответствующих правовых отношений. Действующее трудовое законодательство не содержит специальных норм, регулирующих временное или частичное выполнение работником своей работы вне стационарного рабочего места» (председатель Мосгордумы А. Шапошников $)^{8}$.

Более явно тенденция разделения сотрудников, работающих в офисе и в удаленном формате, проявится в перспективе ближайших 5-7 лет, в результате чего компании откажутся от значительной части арендуемых площадей, однако, в связи с дистанционной коммуникацией увеличатся риски корпоративной информационной безопасности. В том числе, возрастут требования к соблюдению сотрудниками цифровой безопасности, увеличится спрос на корпоративные подписки цифровых бизнес-сервисов.

\begin{tabular}{|c|c|c|}
\hline Гипотеза & $\begin{array}{l}\text { Краткосроч- } \\
\text { ный прогно3 } \\
\text { (1-3 года) }\end{array}$ & $\begin{array}{l}\text { Среднесрочный } \\
\text { прогноз (5-7 лет) }\end{array}$ \\
\hline $\begin{array}{l}\text { Работа из дома } \\
\text { менее эффективна, } \\
\text { а значит, для } \\
\text { сохранения } \\
\text { прежней } \\
\text { продуктивности } \\
\text { приходится } \\
\text { работать больше } \\
\text { времени }\end{array}$ & $\begin{array}{l}\text { В ближайшее } \\
\text { время люди } \\
\text { будут вынуждены } \\
\text { работать } \\
\text { за пределами } \\
\text { официального } \\
\text { рабочего графика } \\
\text { и за пределами } \\
\text { офиса }\end{array}$ & $\begin{array}{l}\text { Постепенный рост } \\
\text { ненормированных } \\
\text { трудовых режимов } \\
\text { остро поставит } \\
\text { вопрос правового } \\
\text { регулирования } \\
\text { таких трудовых } \\
\text { отношений }\end{array}$ \\
\hline
\end{tabular}

Задолго до пандемии коронавируса становилось очевидным, что цифровизация многократно повышает требования к интеллектуальным и творческим способностям человека, к его психофизическим возможностям. Возникла проблема безработных поневоле, т.е. людей, находящихся в активном возрасте, но чьи способности к труду не отвечают новым требованиям работодателей.

Из-за пандемии многим предприятиям пришлось приостановить свою работу или продолжить ее удаленно, обеспечивая режим самоизоляции сотрудников. По результатам опроса бизнеса в период пандемии перевела сотрудников на удаленный формат работы треть российских предприятий $(33 \%)^{9}$

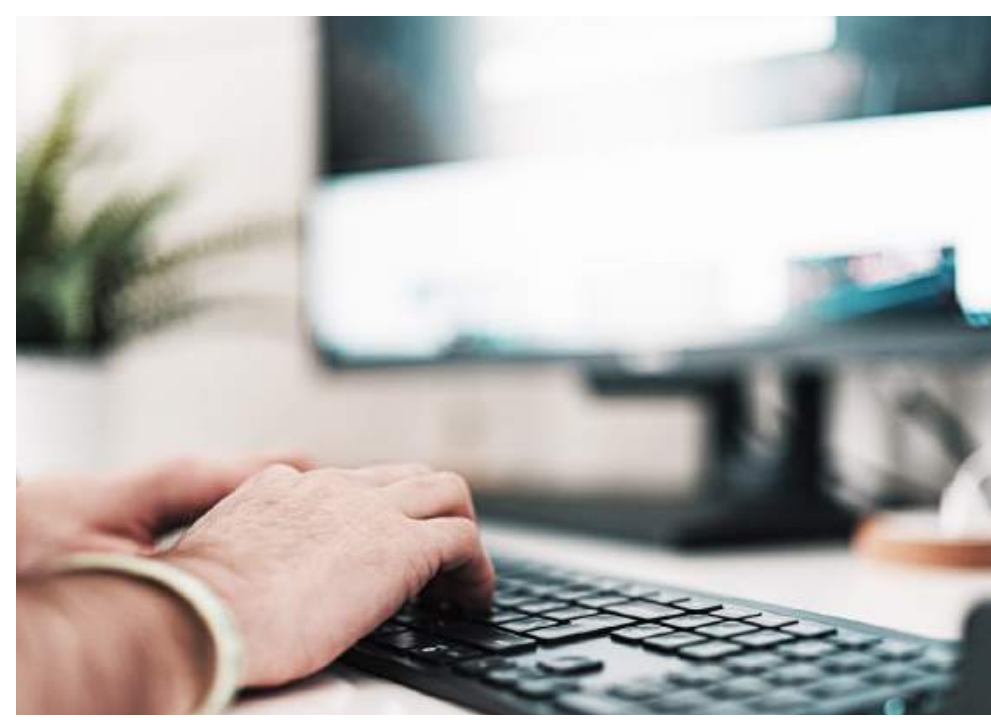

«Новая нормальность»: как изменится Россия после пандемии» / Газета.Ru от 28.04.2020/ Доступно по ссылке: https://m.gazeta.ru/social/2020/04/28/13065343.shtml

«Мосгордума предложила закрепить возможность удаленной работы в Трудовом кодексе» / Интерфакс 27.05.2020 / Доступно по ссылке: https://www.interfax.ru/ moscow/710536

\footnotetext{
Спецпроект НАФИ «Влияние коронавируса на бизнес». Часть 2 «Человеческий капитал: сокращения персонала и удаленный формат работы» / Доступно по ссылке: https://nafi.ru/projects/predprinimatelstvo/rossiyskiybiznes-i-koronavirus-vtoraya-chast-chelovecheskiy-kapitalsokrashcheniya-personala-i-udal//
} 
«Какие из следующих изменений произошли

в вашей компании в отношении сотрудников?»

в \% от всех опрошенных предпринимателей

Отправка сотрудника в отпуск за свой счет

Перевод сотрудника на удаленный/дистанционный формат работы

Снижение размера заработной платы сотрудника

Отмена системы мотивации (социальный пакет, премии, бонусы и т. п.)

Увольнение/сокращение сотрудников

Перевод сотрудников на другие должности с изменением их должностных обязанностей

Другое

Затрудняюсь ответить

Ничего из перечисленного

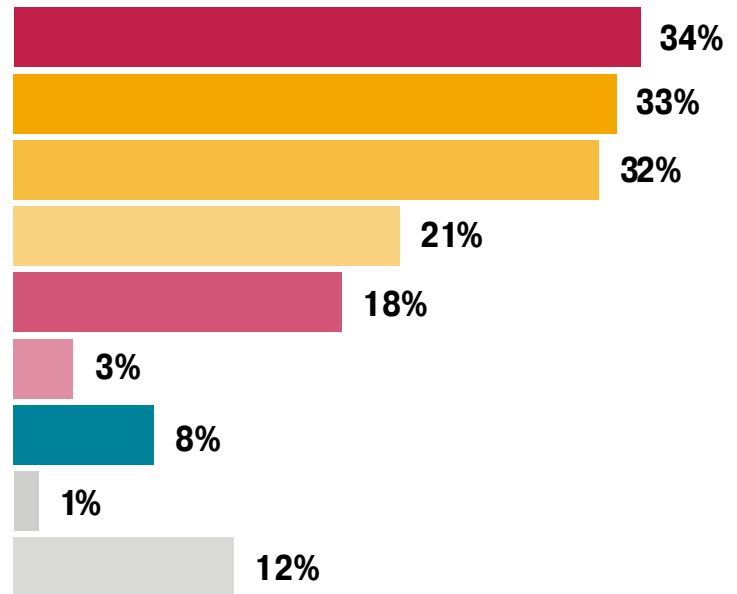

Источник: всероссийский опрос руководителей МСБ, n=1500, НАФИ, апрель 2020 года

Из числа компаний, организовавших удаленную работу сотрудников, перевести весь или почти весь штат сотрудников на удаленку удалось только 35\% организаций. Каждая третья компания (30\%), вводившая такую меру, перевела на удаленный формат работы до четверти своих сотрудников.

\section{«Какая доля сотрудников компании перешла} на формат удаленной работы?»

в \% от всех опрошенных предпринимателей, которые перевели сотрудников на дистанционный формат

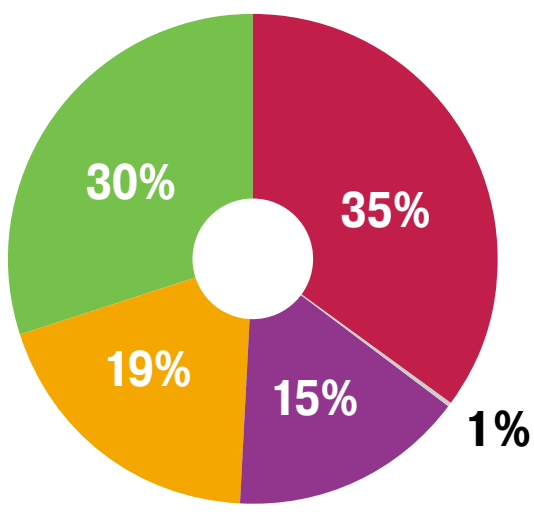

$1-25 \%$ от всех сотрудников компании

$26-50 \%$ от всех сотрудников компании

$\mathbf{5 1 - 7 5 \% ~ о т ~ в с е х ~ с о т р у д н и к о в ~ к о м п а н и и ~}$

76-100\% от всех сотрудников компании

Затрудняюсь ответить 
Большинство предпринимателей, которые полностью или частично перевели штат на удаленный формат работы, отметили снижение эффективности сотрудников - об этом заявили 82\% представителей бизнеса. Каждый третий при этом отметил, что эффективность работы снизилась

«Как бы вы оценили

эффективность работы

\section{СВОИх СОтрУДНИКОВ}

\section{на удаленке по сравнению \\ с обычным режимом?»}

в \% от всех опрошенных предпринимателей, которые перевели сотрудников на дистанционный формат

Источник: всероссийский опрос руководителей МСБ, n=1500, НАФИ, апрель 2020 года

Многие сотрудники, как и работодатели, отметили снижение эффективности труда при переходе на дистанционный формат работы. Так, по результатам исследования, проведенного среди работающих и переведенных на удаленный формат жителей Москвы и Московской области, $40 \%$ отмечают снижение собственной эффективности.

«Как бы вы оценили эффективность вашей работы на удаленке по сравнению с обычным режимом?»

в \% от всех опрошенных, работающих удаленно

Источник: опрос жителей Москвы и Московской области, $\mathrm{n}=900$, НАФИ, апрель 2020 года сильно. 14\% предпринимателей указали, что производительность не изменилась. Примечательно, что никто из предпринимателей не отметил повышения эффективности труда сотрудников в удаленном режиме.

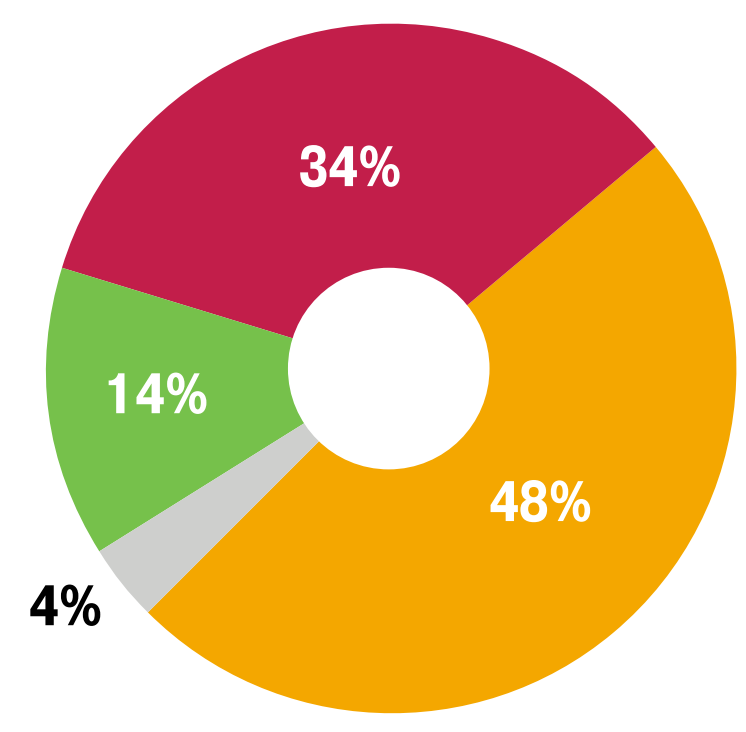

Сильно снизилась

Скорее снизилась

Не изменилась

Затрудняюсь ответить

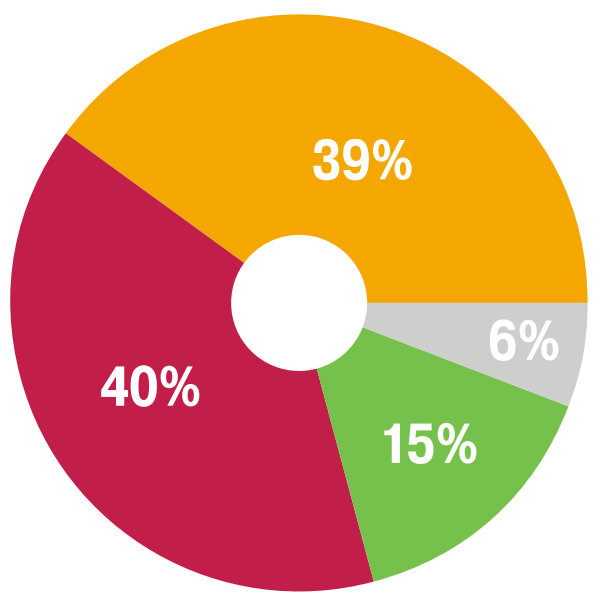

Снизилась

Не изменилась

Повысилась

Затрудняюсь ответить 
В числе самых распространенных причин снижения своей эффективности работники чаще всего указывали на возникающие сложности при дистанционном решении вопросов (назвали 55\% опрошенных, отметивших спад собственной эффективности), невозможность сосредоточиться на работе из-за родственников или домашних дел (24\% и 22\% соответственно). Каждый пятый (18\%) отметил наличие трудностей с самоорганизацией, 16\% - технические проблемы.

\section{«Почему эффективность вашей работы}

\section{на удаленке снизилась?»}

в \% от всех работающих удаленно опрошенных, отметивших снижение собственной эффективности

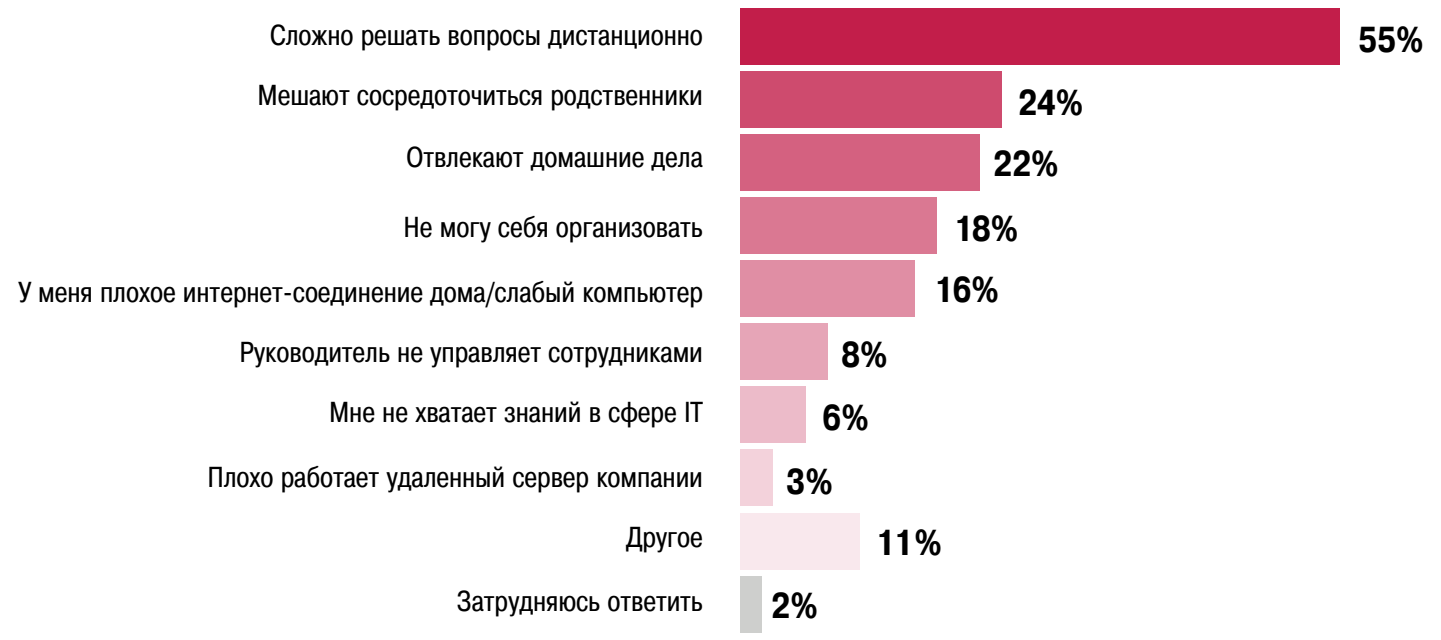

Источник: опрос жителей Москвы и Московской области, n=900, НАФИ, апрель 2020 года

Сотрудники, вынужденные в связи с самоизоляцией вести работу удаленно, в свою очередь, разделились на две условные группы - тех, кто до этого имел опыт удаленной работы (в том числе, работы из дома с ненормированным графиком), и тех, кто опыта удаленной работы не имел, но в спешке стал организовывать в квартире рабочую среду - п плане мебели, телекоммуникаций и даже установления с близкими новых домашних правил. Это явление получило название «домашний офис» (home-office).

«Раньше у меня было резко негативное отношение к ненормированному графику: у меня восьмичасовой рабочий день, и за эти рамки я выходить не хочу. Сейчас у меня рабочий день даже сократился: концентрируешься проще и наслаждаешься жизнью. Хотя если вечером позвонит клиент, это нормально - сейчас новая реальность, и ее нужно принимать. Необходимо просто адаптировать свой график к новым условиям» [специалист в сфере digital-pr, женщина, 33 года, Женева]

Те, кто имел опыт удаленной работы и до этого, особых перемен ни в обстановке, ни в новом формате работы, ни в продуктивности не почувствовали.

«На моей продуктивности эта ситуация не сказалась, мы и до этого работали удаленно, с ненормированным графиком. Но я вижу, как это сказалось на других» [руководитель компании, женщина, 34 года, Уфа]

Главное преимущество таких людей - это найденный ранее баланс работы и личной жизни. Такой баланс требует от человека высокого уровня рефлексии - максимально критичной оценки своей продуктивности и, одновременно, понимания ценности своего здоровья, личностного роста и отношений с близкими. 
«Моя коммуникация по работе стала более точечной. Раньше было до пяти поездок и встреч в день, и это порой было непродуктивно. Сейчас я могу сконцентрировать усилия на конкретных вещах» [руководитель компании, женщина, 34 года, Уфа]

«Из-за привычки работать из дома уже сформирован строгий график дня и работы. Нет сдвига в сторону развлечений, скорее, в сторону проведения времени с ребенком» [Консультант-аналитик, мужчина, 41 год, Вашингтон]

\section{ИЗМЕНЕНИЯ НА РЫНКЕ ТРУДА}

Намечающиеся тенденции ближайшего будущего это рост безработицы и снижение зарплат от 10\% до 30\%. Последнее особенно коснется сотрудников наиболее пострадавших от пандемии отраслейтуризма, авиации, ресторанов и гостиниц, eventагентств, фитнес-клубов.

Согласно опросам НАФИ, большинство предпринимателей пессимистично оценивают перспективы нормализации ситуации в их отрасли. Почти половина (43\%) считают, что ситуация вернется в нормальное состояние не ранее, чем через год, 14\% полагают, что - через два-три года ${ }^{10}$.

Говоря о кадровых перспективах, более половины предпринимателей (55\%) считают, что в ближайшие три месяца штат в их компаниях сократится, 29\% говорят о том, что число сотрудников не изменится. Только 3\% предпринимателей планируют увеличивать штат.
Представляется, что самоизоляция заставит многих переосмыслить ценность собственного здоровья, личного времени и отношений с близкими, однако экономический спад после кризиса будет требовать от людей работать больше, чем прежде. Поэтому «домашний офис» станет для многих не альтернативой корпоративному офису, а его дополнением, логичным продолжением восьмичасового рабочего дня.
«По вашим ожиданиям, число сотрудников вашей компании в ближайшие три месяца увеличится, уменьшится или не изменится?»

в \% от всех опрошенных предпринимателей

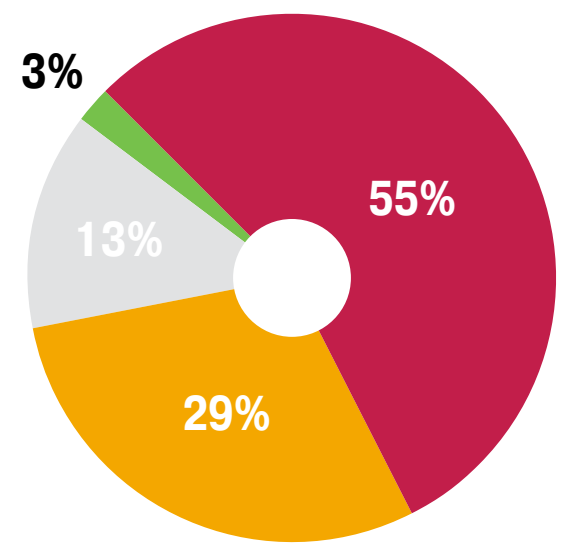

Уменьшится

Не изменится

Увеличится

Затрудняюсь ответить 
По прогнозам экономистов, после пандемии ситуация в экономике будет ухудшаться и к концу года 5,2 млн россиян, работающих по найму, могут остаться без работы. То есть на конец 2020 года количество безработных превысит 10 млн человек - их будет в три раза больше, чем в докризисный период ${ }^{11}$.

Разумеется, кадровая оптимизация в форме сокращений и перевода в неоплачиваемый отпуск, в первую очередь, коснулась тех, кто не мог работать в удаленном формате. Эта же тенденция, ярко подсвеченная коронавирусом, проявилась еще несколько лет назад в Европейском союзе, где на рынок труда вышло большое число безработных - их объединяло, кроме прочего, и то, что их уровень цифровой грамотности был в два и более раз ниже, чем у среднестатистического работающего европейца ${ }^{12}$.

Гипотеза компетенций повысит конкуренцию в среднем звене офисных работников

\section{Краткосрочный прогноз (1-3 года)}

Рост конкуренции на рынке труда из-за высвободившейся рабочей силы снизит зарплаты среднего звена и затормозит восстановление доходов до прежнего уровня, потребовав от менеджеров повышения квалификации
Среднесрочный прогноз (5-7 лет)

Все большее число профессий будет связано с использованием цифровых технологий. Ключом к успеху станет не просто цифровая грамотность, а профессиональная цифровая компетентность - то есть способность применять конкретные цифровые технологии в своей профессиональной деятельности

Цифровизация экономики еще задолго до пандемии заставила многих работающих россиян задуматься над знанием информационных технологий. Опрос НАФИ, проведенный за год до пандемии, показал, что каждый третий работающий россиянин рискует потерять работу, если не будет проходить обучение в сфере информационных технологий, а каждый второй (51\%) отмечал тогда, что по месту работы ежегодно растут требования к знанию сотрудниками информационных технологий ${ }^{13}$.

\section{Доля респондентов от общего количества опрошенных, согласных со следующими утверждениями, в \% от общего числа работающих россиян ( $\mathrm{n}=1145)$}

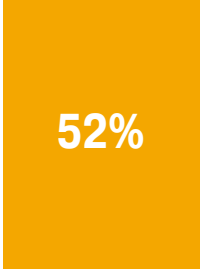

На вашем месте работы уже сейчас требуется обязательное знание информационных технологий

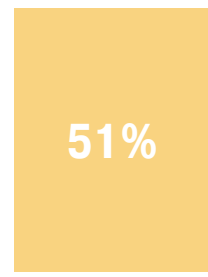

На вашем месте работы требования к знанию сотрудниками информационных технологий ежегодно растут

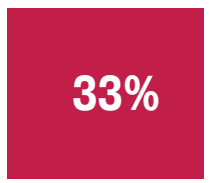

Вы рискуете потерять работу, если не будете обучаться информационным технологиям

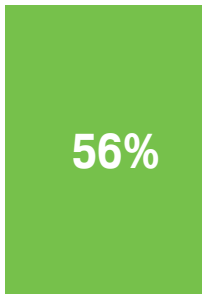

Если бы вы знали информационные технологии лучше, то смогли бы успешнее трудоустроиться

12 Digital skills in the EU labour market / Доступно по ссылке: https://op.europa.eu/en/publication-detail/-/publication/cb9ff359-e2c9-11e6ad7c-01aa75ed71a1 https://op.europa.eu/en/publication-detail/-/publication/cb9ff359-e2c9-11e6-ad7c-01aa75ed71a1

13 Пресс-релиз НАФИ от 01.03.2019 «Каждый второй россиянин хочет улучшить свои знания и навыки в сфере информационных технологий» / Доступно по ссылке: https://nafi.ru/analytics/kazhdyy-vtoroy-rossiyanin-khochet-uluchshit-svoi-znaniya-i-navyki-v-sfereinformatsionnykh-tekhnolog 
Рост явной и скрытой безработицы после кризиса будет увеличивать конкуренцию на рынке труда, где все более важными для работодателей становятся цифровые компетенции. В большинстве отраслей такая конкуренция спровоцирует временное снижение зарплат и, одновременно, рост требований к работникам. В свою очередь, сотрудники младшего и среднего звена в стремлении получить более высокооплачиваемую работу будут активно обращаться к дополнительному обучению и программам повышения квалификации. Эта тенденция проявляется уже сейчас: каждый третий россиянин на самоизоляции занимался учебой или саморазвитием (36\%). Больше других обучению посвящали время молодые россияне (59\%). Чаще всего на самоизоляции изучали иностранные языки, на втором месте - развивали цифровые компетенции (программирование/пользование специальными программами или сервисами).

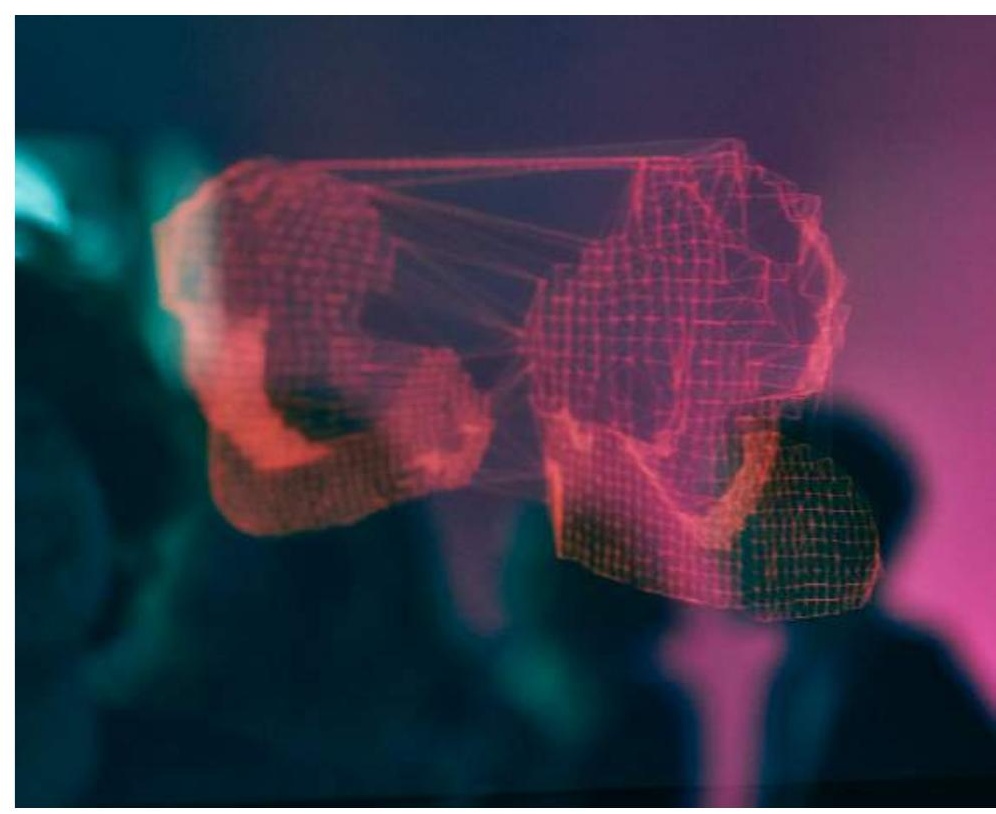

\section{«Ранее вы указали, что занимаетесь саморазвитием, проходите обучение. Чему именно вы учитесь?»}

в \% от всех опрошенных, которые уделяют время саморазвитию

( 10 самых распространенных вариантов ответа)

Изучение иностранных языков

Программирование/Іт/компьютерные программы/анализ данных

Чтение книг

Повышение квалификации

Спорт/танцы/йога

Психология/саморазвитие/медитация/педагогика

Маркетинг/реклама/социология/экономика/финансы

Вязание/рукоделие/кулинария/цветоводство/садоводство

Искусство/архитектура/дизайн/живопись/фотография

История

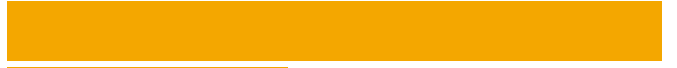

$35 \%$

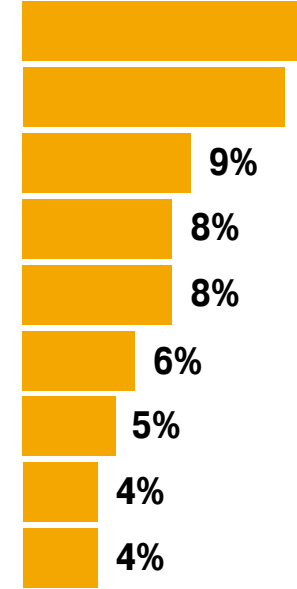

$15 \%$

$14 \%$

$9 \%$

$8 \%$

$6 \%$

$5 \%$

$4 \%$

Источник: всероссийский опрос населения, n=1600, НАФИ, апрель 2020 года

В то же время исследования, проводимые сегодня в Европе, показывают, что компании, сумевшие сохранить 100\% или большую часть своего штата, завоевали очень высокую лояльность сотрудников и повысили привлекательность своего бренда как работодателя на рынке труда ${ }^{14}$. Ежегодное исследование лояльности россиян своим работодателям (индекс еNPS) в 2020 году Аналитический центр НАФИ планирует провести осенью. Его результаты будут опубликованы на нашем сайте nafi.ru. 


\section{ЭКОНОМИКА \\ TРАНСПОРТА}

$\begin{array}{lll}\text { Гипотеза } & \text { Краткосрочный прогноз (1-3 года) } & \text { Среднесрочный прогноз (5-7 лет) } \\ \text { Люди в крупных городах перейдут } & \text { Увеличится число пробок, спрос } & \text { Вырастет спрос на услуги проката } \\ \text { на персональный транспорт-авто, } & \text { на ГСМ и автотовары } & \text { автомобилей и велосипедов, } \\ \text { каршеринг, велосипед } & & \text { запрос на развитие дорожной } \\ & & \text { и велоинфраструктуры }\end{array}$

Страх перед коронавирусом в обществе придал автомобилю новую роль ${ }^{15}$. Автомобиль стал не просто средством передвижения, а фактически превратился в мини-укрытие на колесах, которое позволяет находиться внутри и снаружи. Разумеется, защитная функция автомобиля была актуальна и раньше, но пандемия и карантин лишь усилили ее.

\section{«Я буду пользоваться в первое время только} личным автомобилем. На личном транспорте я уединился в себе. А в общественном транспорте и я могу заразить, и меня могут заразить» [руководитель строительной компании, мужчина, 55 лет, Москва]

«Мы стараемся ездить на машине. Перемещаешься индивидуально, безопасно для здоровья. Такси здесь в пять раз дороже, чем в Москве, мы им не пользуемся. Рядом с домом перемещаемся на велосипеде, а куда нельзя на нем доехать, едем на машине [специалист в сфере digital-pr, женщина, 33 года, Женева]
В пандемию автолюбители смогли чувствовать себя безопасно и отчасти свободно.

Личный автомобиль позволил безопасно перемещаться на значительные расстояния (например, от городской квартиры до загородного дома), делать необходимые запасы продуктов и хозяйственных товаров, помогать друзьям и родственникам.

С учетом того, что ряд АЗС предлагает бесконтактную заправку и онлайн-оплату топлива из салона автомобиля, личный автомобиль стал единственным видом транспорта, на котором можно гарантированно бесконтактно добраться из пункта А в пункт В.

Согласно данным опроса, проведенного Аналитическим центром НАФИ в мае 2020 года, несмотря на высокую стоимость парковки и большое количество пробок, после окончания пандемии работающие москвичи и жители Московской области планируют снизить количество поездок на метро и наземном транспорте в пользу автомобильных.

Так, на работу на машине планирует ездить 25\% опрошенных (раньше их доля составляла 21\%), а на такси - 4\% горожан (до пандемии на такси на работу ездил $1 \%$ опрошенных).
The car becomes an unexpected hero during lockdown / The New York Times (23.05.2020). Доступно по ссылке: https:// www.nytimes.com/2020/05/23/us/drive-by-graduation-babyshower-drive-in-coronavirus.html 
«Каким видом транспорта для поездок на работу вы чаще всего пользовались/будете пользоваться?»

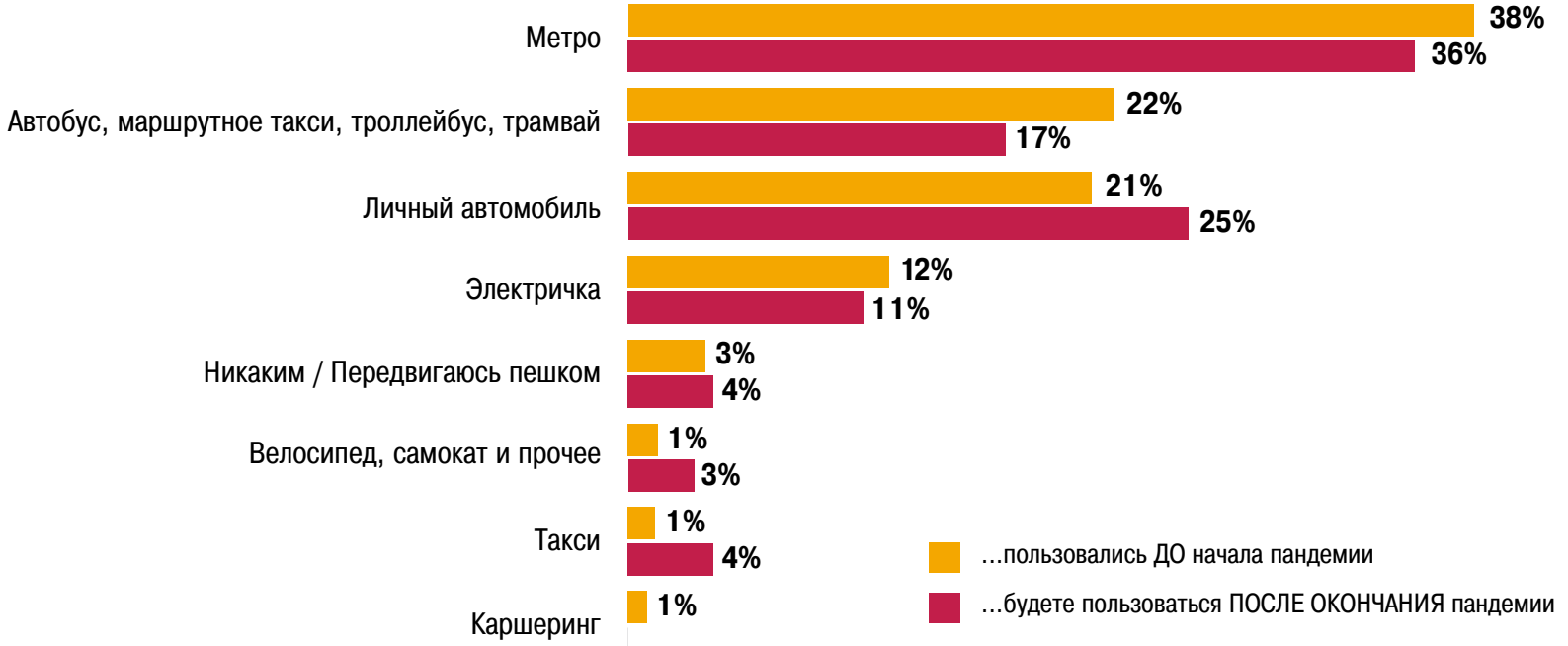

«Каким видом транспорта для поездок в личных целях вы чаще всего пользовались/будете пользоваться?»

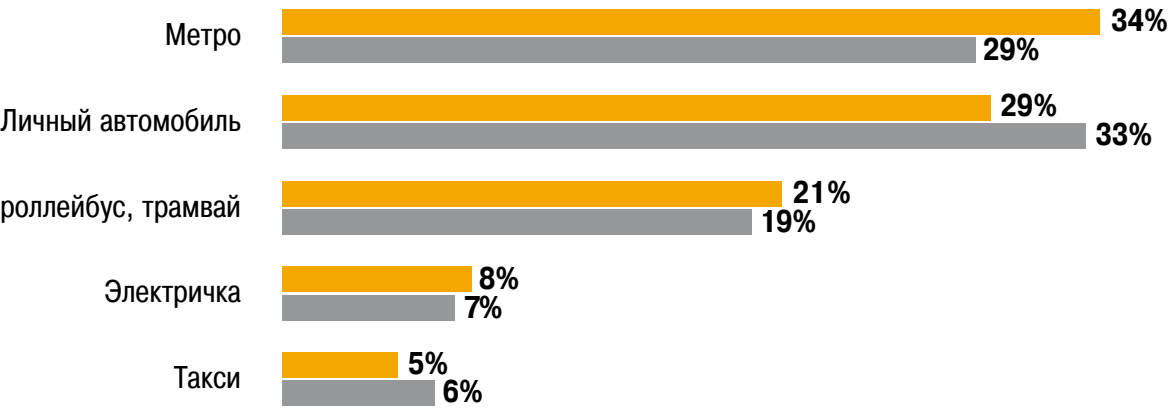

Велосипед, самокат и прочее 
Несмотря на постепенный рост финансовой грамотности ${ }^{16}$, культура сбережений и долгосрочного финансового планирования оказалась мало распространена. Большинство россиян не делали сбережений и не имеют необходимой финансовой «подушки безопасности» на случай потери работы. Многие россияне имели очень краткосрочный горизонт планирования.

\section{«К началу пандемии}

\section{были ли у вас (вашей семьи) сбережения, накопления?»}

в \% от всех опрошенных

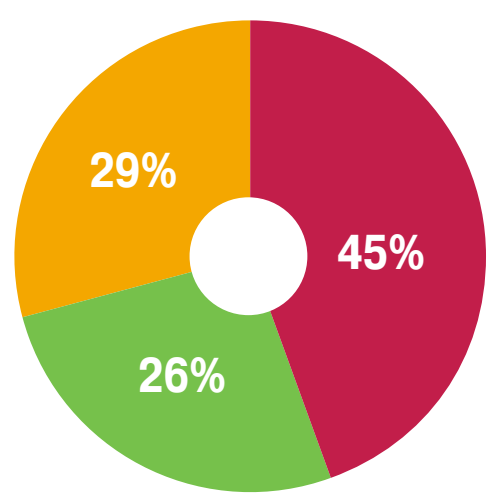

Сбережений почти или совсем не было

Сбережения были, но их было недостаточно

Да, и их было достаточно, чтобы пережить самоизоляцию, даже если бы вы потеряли все источники дохода

Источник: всероссийский опрос населения, n=600, НАФИ, июнь 2020 года

В итоге отсутствие сбережений или их недостаточный объем, наряду с внешними обстоятельствами (потерей работы или иных источников дохода), привели к тому, что каждый второй россиянин столкнулся с серьезными финансовыми трудностями в период пандемии. Причем почти вдвое чаще с финансовыми трудностями сталкивались именно те, кто до пандемии не делал сбережений.

Результаты второй волны измерения уровня финансовой грамотности россиян / Доступно по ссылке: https://nafi.ru/ analytics/indeks-finansovoy-gramotnosti-rossiyan-vyros-minfinpredstavil-issledovanie-znaniy-navykov-i-ustanov/
«Пришлось ли вам

столкнуться с финансовыми

трудностями, недостатком

средств в период

самоизоляции?»

в \% от всех опрошенных и по группам россиян, имевших и не имевших сбережения к началу

пандемии

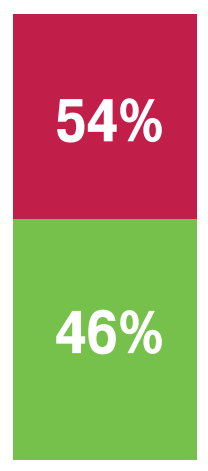

Bce опрошенные

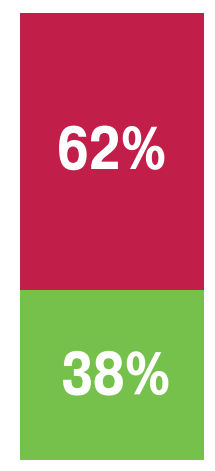

Россияне, которые имели сбережения к началу пандемии

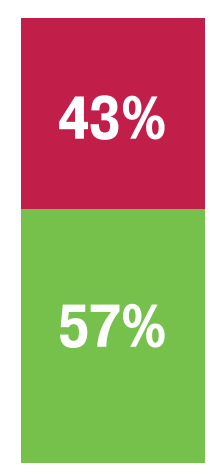

Не имели сбережений
Источник: всероссийский опрос населения, n=600, НАФИ, июнь 2020 года

Согласно опросу НАФИ, проведенному незадолго до коронакризиса, в случае потери основного источника дохода 42\% россиян могли бы оплачивать все необходимые расходы - без займов у близких и оформления кредитов - в течение одного месяца, четверть (26\%) - менее трех месяцев. Равные доли -по 10\% - смогут прожить на свои сбережения от трех до шести месяцев и более полугода. В среднем при потере работы накоплений россиян хватит на 63 дня ${ }^{17}$. При этом, чем больше детей в семье, тем меньше срок, на который хватит накоплений в случае потери работы родителями. Для россиян с одним ребенком, среднее количество дней, на которое хватит накоплений - 65, для россиян с двумя детьми -62, с тремя-52. 
«Если ваша семья потеряет основной источник дохода, как долго вы сможете оплачивать все необходимые расходы, не занимая денег?»

в \% от всех работающих россиян

«До пандемии обладал финансовым резервом привычка иммигрантов иметь запас на «черный день». Кризисная ситуация активировала деловые навыки - смог получить новые заказы, проекты и даже повысить доходы» [Консультант-аналитик, мужчина, 41 год, Вашингтон]

Сегодня каждый второй россиянин (56\%) ожидает ухудшения своего материального положения в следующие 12 месяцев ${ }^{18}$. Оно происходило довольно заметно и в прошедшие месяцы.

«Как бы вы оценили

материальное положение вашей семьи?»

в \% от всех опрошенных

Источник: всероссийские опросы населения, n=1600, НАФИ, февраль и апрель 2020

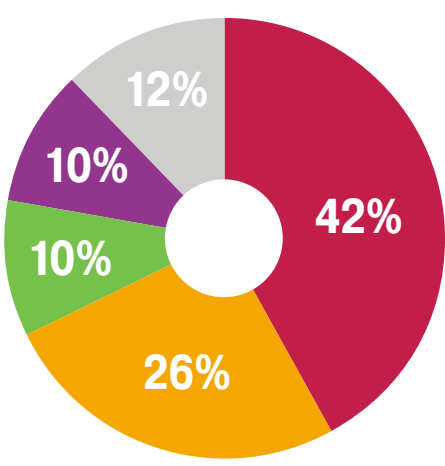

Меньше месяца

Не меньше месяца, но меньше трех месяцев

Не меньше трех месяцев, но меньше полугода

Полгода и более

Затрудняюсь ответить

Источник: всероссийский опрос населения, $\mathrm{n}=1600$, НАФИ, февральмарт 2020 года
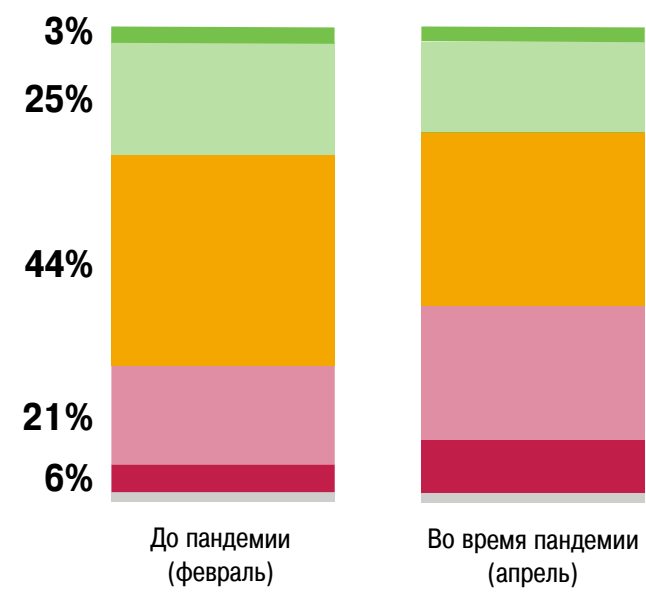

$3 \%$

$19 \%$

$36 \%$

$28 \%$

$11 \%$

Мы можем позволить себе практически все: машину, квартиру, дачу и многое другое

Мы можем без труда купить холодильник, телевизор, мебель, но на автомобиль денег нет

Денег хватает на продукты и одежду, но покупка холодильника телевизора, мебели - для нас проблема

На продукты денег хватает, но покупка одежды уже затруднительна

Мы едва сводим концы с концами. Денег не хватает даже на продукты Отказ от ответа 
Ухудшение материального положения заставит россиян в ближайшее время включать экономный и сберегающий режим - меньше тратить и делать больше сбережений. Многие поняли, что были совсем не готовы к такому повороту и не имеют финансовой подушки безопасности, чтобы прожить автономно даже недолгое время. Однако эта тенденция видится нами лишь в краткосрочной перспективе - как ответная реакция на случившееся.
В то же время последние кризисы показали, что уже через 3-4 года россияне возвращаются к краткосрочному финансовому планированию и необоснованному кредитному поведению.

Если полгода-год назад установки россиян на сбережения были не такими явными (39\% были уверены, что делать сбережения вообще не нужно), то сегодня их доля снизилась почти в 10 раз.

\section{«На ваш взгляд, как следует распоряжаться}

\section{доходами в повседневной жизни?»}

в \% от всех опрошенных

$\begin{array}{ll}\begin{array}{ll}\text { До пандемии } \\ \text { (сентябрь 2019),\% }\end{array} & \text { После } \\ & \text { пандемии } \\ \text { (июнь 2020),\% }\end{array}$

Сначала что-то отложить, а остальные деньги
тратить на текущие нужды
Тратить деньги на текущие нужды, а что остается - отк
Тратить все деньги на текущие нужды и ничего не откл
Затрудняюсь ответить
Источник: всероссийские опросы населения, НАФи, сентябрь 2019 год
Примечательно, что установка «сначала отложить,
Приставшиеся деньги тратить» больше характер-
на для молодых женщин (41\%) и в целом россиян
старше 55 лет (35\%), тогда как установки «сберегать
то, что остается после текущих трат» и вообще
не делать сбережений -характерны для мужчин
молодого и среднего возрастов.

Краткосрочная нацеленность на сбережения будет способствовать росту спроса на сберегательные банковские продукты. В свою очередь, люди, чьих доходов не хватает на текущую жизнь, после пандемии будут обращаться за займами и кредитами. В обоих случаях усиление интереса к финансовым продуктам будет сопровождаться и активизацией мошенничества.

Произойдет рост финансового мошенничества, осуществляемого через интернет и по телефону
Первые шаги к удаленной идентификации (биометрия) и цифровизация банковской отрасли дополнят контролирующие и правоохранительные функции государства
Технологизация мошенничества до уровня использования в этих целях искусственного интеллекта приведет к появлению его новых, трудно обнаруживаемых форм. В свою очередь, это увеличит число случаев мошенничества и объемов незаконно списанных средств 
Экономические кризисы и связанное с ними сокращение доходов традиционно являются временем активизации финансовых мошенников. В последние годы, особенно в аспекте перехода на дистанционные каналы обслуживания, оказалось очевидным, что скорость развития мошеннических систем в банковской сфере существенно превышает скорость построения защиты от таких противозаконных действий.

Мониторинг финансовой грамотности, проводимый ежегодно Минфином России и НАФИ, показывает, что до сих пор россияне не научились в достаточной мере различать мошеннические схемы и финансовые пирамиды ${ }^{19}$.
В рамках нашего исследования респондентам был предложен список из семи возможных признаков финансовых пирамид, среди которых нужно было определить не менее трех верных. К ним относятся отсутствие лицензии, завышенная гарантированная доходность инвестиций, отсутствие подтвержденного опыта на рынке, непрозрачные условия договора.

В целом уверенно способны распознать финансовую пирамиду около четверти (26\%) жителей РФ

Какие из этих характеристик являются, на ваш

взгляд, признаками финансовой пирамиды?»

\section{Способность распознать финансовую пирамиду, в \%}

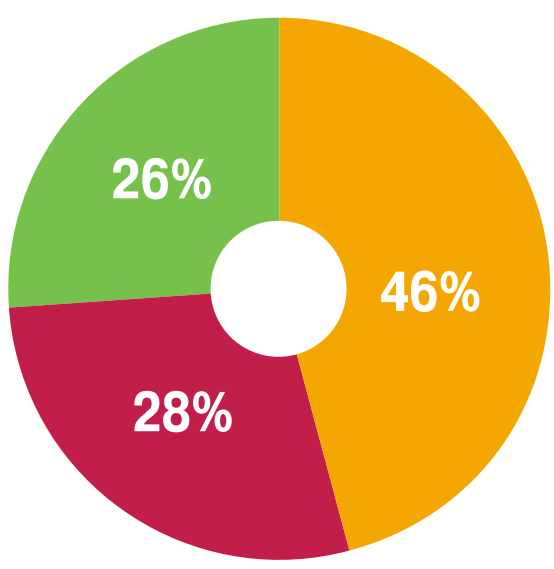

Способны распознать финансовую пирамиду (3 и более верных признака)

Отчасти способны распознать финансовую пирамиду (1-2 верных признака)

Не способны распознать финансовую пирамиду (ни одного верного признака) 
В возрасте 25-45 лет способности к распознаванию финансовых пирамид проявляются особенно сильно (29-31\%, больше, чем в других возрастных группах). Далее с возрастом уязвимость в аспекте распознавания финансовых пирамид растет.

\section{Доля способных распознать финансовую пирамиду в возрастных группах, в \%}

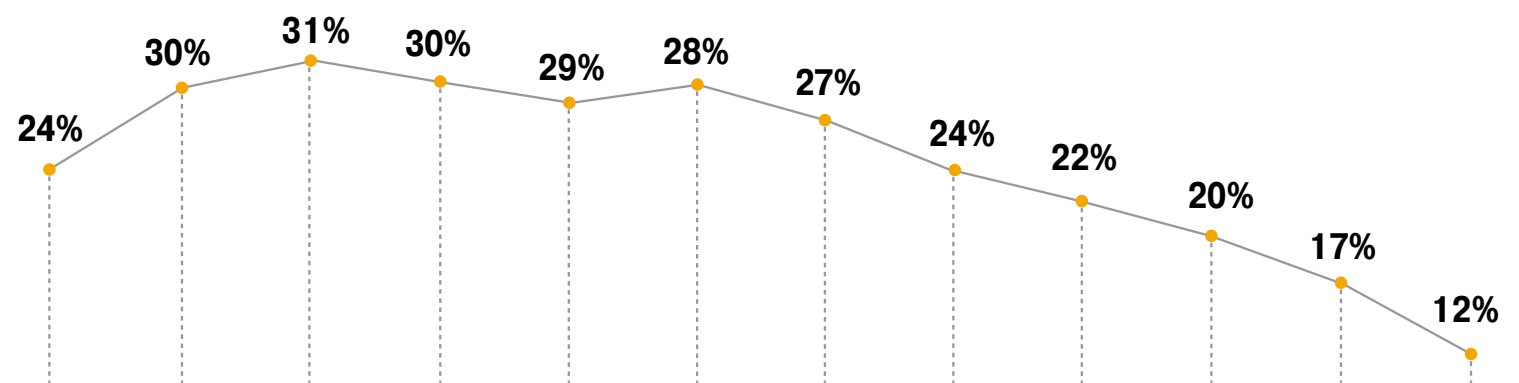

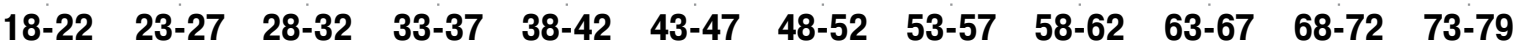

Возраст, лет

Люди с высоким личным доходом лучше справляются с распознаванием финансовых пирамид. Соответственно, чем выше материальный статус семьи, тем лучше способности к распознаванию такой формы мошенничества, как пирамида. В зоне опасности остаются люди со средним и ниже среднего уровнем достатка.

\section{Доля способных распознать финансовую} пирамиду в различных доходных группах,

в \% в целом и по группам с разной покупательной способностью

\section{Все опрошенные}

Мы едва сводим концы с концами

На продукты денег хватает, но покупка одежды уже затруднительна

Денег хватает на продукты и одежду, но покупка телевизора, мебели - проблема

Мы можем без труда купить бытовую технику, мебель, но на большее денег нет

Мы можем позволить себе практически все

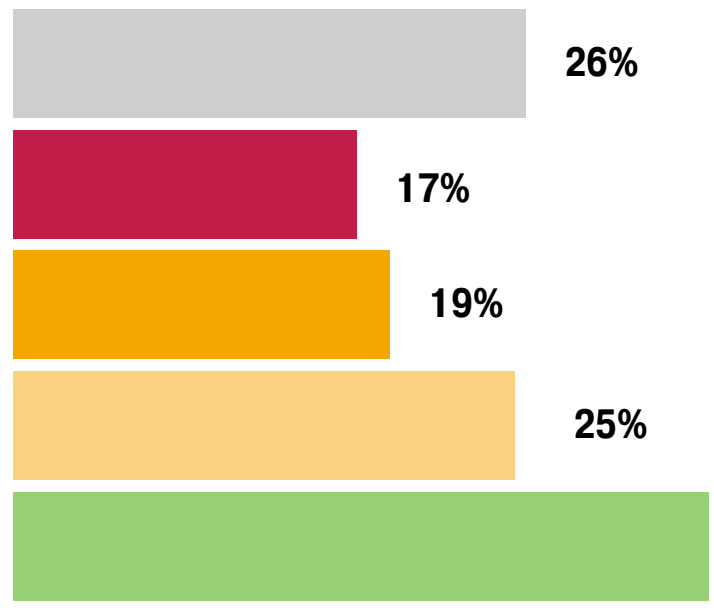

$36 \%$

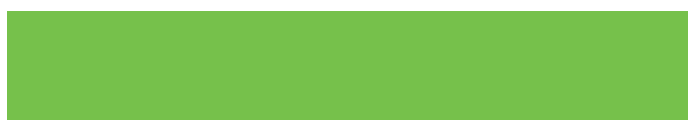


Хорошо понимая, кто входит в перечисленные группь риска, мошенники станут изобретать все более новые и технологичные способы противоправных действий. Учитывая текущие масштабы телефонного мошенничества (когда преступник представляется сотрудником банка), можно быть уверенным в значительных организационно-технических, кадровых и управленческих ресурсах мошеннических преступных группировок. Разумеется, этих ресурсов им будет достаточно для инвестирования в новые технологичные мошеннические инструменты - защиту от которых, главным образом, себе может обеспечить только сам человек, если он обладает достаточным уровнем знаний о признаках мошеннических действий (когда просят сообщить персональные данные, используют прием запугивания, настаивают на срочности решения вопроса; когда отсутствуют корпоративные контакты для обратной связи) и достаточной цифровой грамотностью, особенно, в части цифровой безопасности ${ }^{20}$.

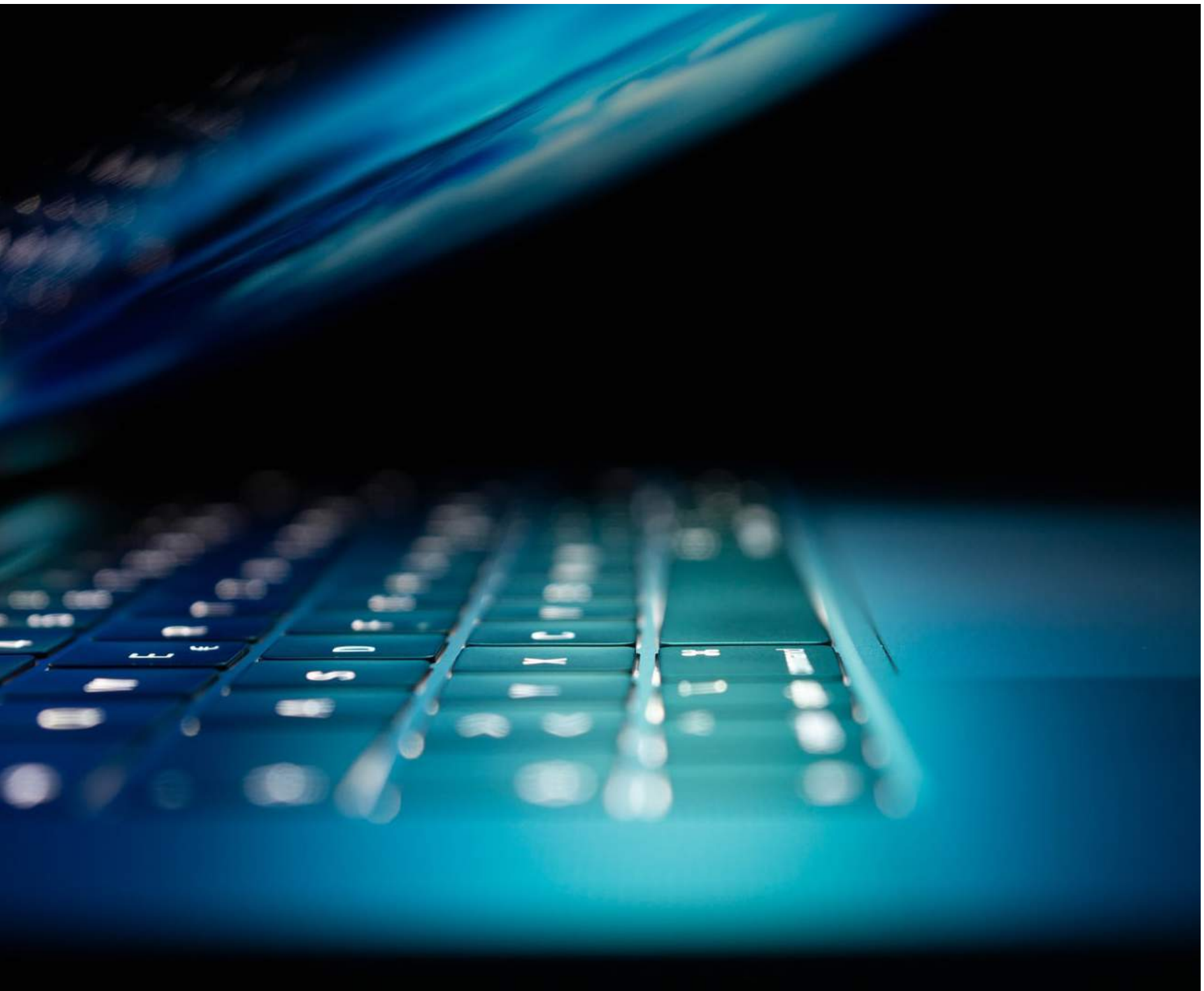




\section{БЕЗНАЛИЧНЫЕ ПЛАТЕЖИ}

В последние годы переход к безналичным формам оплаты происходил постепенно, в основном будучи связанным с темпами распространения главного платежного инструмента - банковской карты. Сегодня подавляющее большинство россиян (82\%) - держатели банковских карт, причем за последние 11 лет их доля выросла с 31\% до 82\%21.

«Каким образом вы обычно осуществляете повседневную оплату товаров и услуг?»

в \% от всех опрошенных

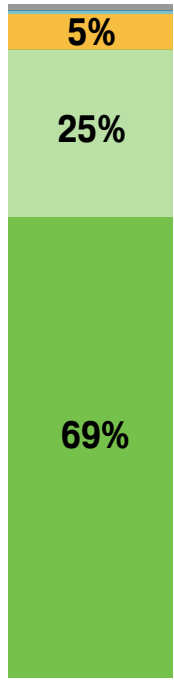

2013

Только наличные

Только безналичные

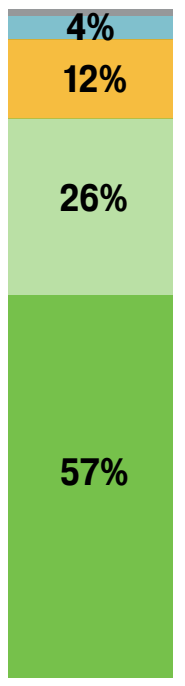

2015

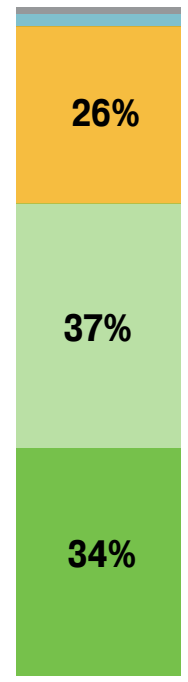

2017

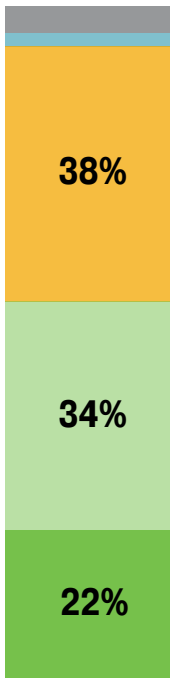

2018

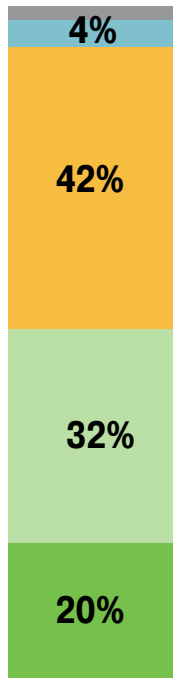

$7 \%$

2019
$41 \%$

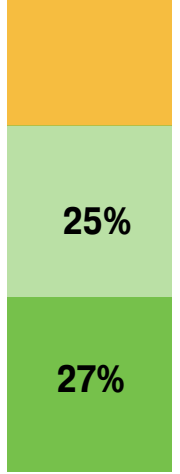

2020

Чаще наличные

Чаще безналичные платежи

Отказ от ответа 


$\begin{array}{lll}\text { Гипотеза } & \text { Краткосрочный прогноз (1-3 года) } & \text { Среднесрочный прогноз (5-7 лет) } \\ \text { После пандемии резко увеличится } & \text { Резкого перехода на безналичные, } & \text { Глобальная цифровизация } \\ \text { доля россиян, оплачивающих покупки } & \text { в т. ч. бесконтактные платежи, } & \text { продолжит выводить на рынок } \\ \text { безналичным способом } & \text { не произойдет-пользование } & \text { финансовых услуг новых } \\ & \text { платежными инструментами среди } & \text { игроков- ІТ-компании. Их успех } \\ \text { россиян будет развиваться темпами, } & \text { будет предопределяться тем, } \\ \text { которые были и до пандемии } & \text { насколько быстро они смогут } \\ & & \text { преодолеть страх небезопасности } \\ & & \text { современныхплатежных } \\ & & \text { инструментов, имеющийся }\end{array}$

В период пандемии россияне стали несколько чаще оплачивать покупки безналичными способами⒉ Это было предопределено как развитием соответствующей платежной инфраструктуры в интернете, куда многие россияне переместили свою покупательскую активность, так и нежеланием использовать наличные деньги в физических торговых точках из-за гигиенических соображений.

Исследование показало, что каждый пятый россиянин (21\%), использовавший до пандемии различные способы оплаты, стал чаще оплачивать покупки безналично. А вот среди тех, кто ранее пользовался только наличными деньгами (19\% россиян), 87\% не поменяли свои предпочтения, несмотря на пандемию, и продолжают пользоваться только наличными.

В странах БРИКС, по данным недавнего опроса Mastercard, после пандемии наблюдается большой рост популярности бесконтактной оплаты: например, в Бразилии 35\% жителей, до этого не использовавших бесконтактную оплату, стали пользоваться ей, ссылаясь на удобство и «чистоту»23. При этом
82\% молодых бразильцев уверены, что продолжат использовать бесконтактные способы оплаты даже после полного окончания пандемии. Эта же тенденция подтверждается статистикой Mastercard: потребители все чаще ищут способы быстрого выхода из магазинов, не касаясь терминалов - число бесконтактных транзакций выросло на 500\% с марта прошлого года. Самый заметный рост бесконтактных платежей-в продуктовых магазинах и аптеках.

В России в ближайшие годы взрывного перехода на бесконтактные платежные инструменты, на наш взгляд, ожидать не стоит - несмотря на хорошую осведомленность о бесконтактных формах оплаты ${ }^{24}$.

Основным барьером для их использования является распространенное мнение о финансовой небезопасности таких платежей, во многом вызванное непониманием технологии, низким уровнем цифровой грамотности отдельных сегментов потребителей.

22 Всероссийский опрос проведен МШУ «СКОЛКОВО» и НАФИ в апреле 2020 года. Опрошено 1612 человек старше 18 лет в 53 регионах России. Результаты доступны по ссылке: https://nafi.ru/analytics/pandemiya-kak-katalizatorperekhoda-k-beznalichnym-platezham/

\footnotetext{
Пресс-релиз НАФИ от 04.03.2020 «Бесконтактные платежи: возврата к наличным не будет» / Доступно по ссылке: https:// nafi.ru/analytics/beskontaktnye-platezhi-vozvrata-k-nalichnymne-budet-/
} 


\section{ППЕРЕХОД НА ОНЛАЙН-ПОКУПКИ}

$\begin{array}{lll}\text { Гипотеза } & \text { Краткосрочный прогноз (1-3 года) } & \text { Среднесрочный прогноз (5-7 лет) } \\ \text { Привыкнув к онлайн-покупкам } & \text { На офлайн-торговлю будет негативно } & \text { С восстановлением экономической } \\ \text { на самоизоляции, люди продолжат } & \text { влиять боязнь заразиться, а покупки } & \text { ситуации и прогрессом в индустрии } \\ \text { заказывать товары онлайн } & \text { в интернете будут сокращаться из- } & \text { электронной коммерции доля } \\ & \text { за ухудшающейся экономической } & \text { покупок, совершаемых онлайн, } \\ & \text { ситуации. В то же время после } & \text { станет превышать офлайн-сегмент } \\ & \text { пандемии россияне будут покупать } & \text { во многих категориях товаров } \\ & \text { онлайн активнее, чем до пандемии, } \\ & \text { но менее активно, чем во время } & \\ & \text { пандемии } & \end{array}$

Опросы, проведенные во время самоизоляции, показали, что до трети (33\%) покупателей планируют меньше ходить в торговые центры и отдельные магазины после завершения карантина 25 . Однако ритейлеры ожидают прихода покупателей, в том числе в ТЦ. В онлайне людям не хватает полноценного покупательского и клиентского опыта. Кроме того, онлайн по-прежнему не воспринимается как основное место покупки во многих категориях - особенно это касается одежды и обуви

Треть россиян (32\%) из числа тех, кто совершает интернет-покупки, стали чаще покупать онлайн на самоизоляции. Тем не менее, большинство россиян (73\%) считают, что по окончании режима самоизоляции будут делать покупки онлайн с той же частотой, что и до пандемии ${ }^{26}$. В то же время, у некоторых россиян привычка делать покупки онлайн останется - поэтому сразу после пандемии можно ожидать рост числа онлайнпокупателей относительно показателей докризисного уровня, при этом средний чек, вероятнее всего, снизится. Покупатели планируют сокращать свои расходы практически во всех категориях из-за опасений в связи с возможным повышением цен и неопределенностью ситуации с доходами.

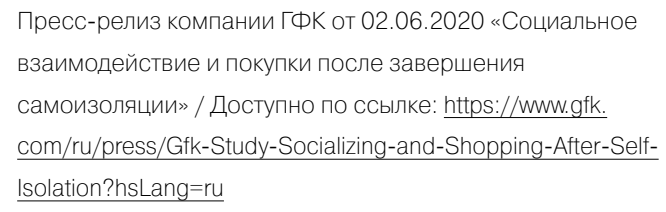

Пресс-релиз компании ГФК от 02.06.2020 «Социальное взаимодействие и покупки после завершения самоизоляции» / Доступно по ссылке: https://www.gfk. com/ru/press/Gfk-Study-Socializing-and-Shopping-After-Self$\underline{\text { Isolation?hsLang=ru }}$

\footnotetext{
Пресс-релиз НАФИ от 26.05.2020 «Россияне привыкли к онлайн-покупкам и готовы переплачивать» //https://nafi. ru/analytics/rossiyane-privykli-k-onlayn-pokupkam-i-gotovypereplachivat/
}

Тем не менее, виртуализация покупательского поведения («Virtual Experience») - закономерный шаг развития цифрового общества. У потребителей формируются новые паттерны выбора товара, продавца, новые критерии доверия. В самой торговле на фоне изменения структуры рынка происходит и изменение маркетинговых и рекламных стратегий, отвечающих новому цифровому поведению потребителей. Цифровизация здесь создает отличные возможности для таргетированной рекламы, сегментации покупателей и индивидуализации продаж. Уже ни для кого не секрет, что лидирующие позиции в сфере торговли будут занимать не гипермаркеты с нескончаемым ассортиментом товаров по сниженным ценам, а онлайн-ритейлеры с сильным штатом IT-специалистов.

Карантинные меры научили не только потребителей покупать онлайн, но и многих ритейлеров - продавать онлайн. Полученный опыт и допущенные ошибки будут пересмотрены и уже в ближайшее время мы увидим на рынке онлайнкоммерции рост конкуренции и предложений от игроков, работавших ранее только офлайн.

В более отдаленной перспективе, вероятно, под влиянием технологий 5G, Al, VR целый ряд сегментов онлайн-торговли, где особенно сильно почувствовали отсутствие в период пандемии «живого покупателя» (бьюти-индустрия, одежда и обувь), получат в онлайне дополнительные возможности для бизнеса и уже не будут так сильно зависеть от физических магазинов. Дополненная и виртуальная реальность в сочетании с голографическими технологиями трансформируют онлайн-шоппинг, помогая покупателю при выборе товара почувствовать себя в «квазиреальных» условиях магазина. 


\section{ИЗМЕНЕНИЕ ПОВЕДЕНИЯ ПОКУПАТЕЛЕЙ В ОФЛАЙН: НОВЫЕ ВЫЗОВЫ И ВОЗМОЖНОСТИ ДЛЯ РИТЕЙЛЕРОВ}

$\begin{array}{lll}\text { Гипотеза } & \text { Краткосрочный прогноз (1-3 года) } & \text { Среднесрочный прогноз (5-7 лет) } \\ \text { Процесс совершения повседневных } & \text { Посещения магазинов, сами покупки } & \text { Изменится система критериев } \\ \text { покупок в ритейле изменится } & \text { будут лучше спланированы, а время, } & \text { выбора товаров: «визуальная» } \\ & \text { проведенное в магазине, будет } & \text { роль упаковки снизится, } \\ & \text { сокращаться } & \text { а информационная -возрастет }\end{array}$

\begin{abstract}
Международные исследования, проводимые, в том числе, в странах, где карантин закончился раньше, показывают, что снижение тревожности при посещении магазинов, предприятий сферы услуг и при использовании общественного транспорта происходит спустя 3-4 недели после снятия ограничительных мер ${ }^{27}$.
\end{abstract}

В то же время пока все больше потребителей говорят о том, что они начинают покупки с детального планирования: еще дома принимается решение, когда лучше всего идти в магазин, чтобы встретить там меньше других покупателей, и в какие магазины лучше идти. Имея выбор, потребители предпочитают супермаркеты с просторными торговыми залами и отделами, с широкими проходами и удобной парковкой. Предпочтение отдается магазинам с большим ассортиментом - люди готовы жертвовать лояльностью отдельным брендам и своими потребительскими привычками в пользу магазинов, позволяющих купить все необходимые товары из списка в одном месте.

Ритейлеры начали задумываться над тем, что они могут предпринять, чтобы обеспечить потребителям чувство безопасности и сделать процесс покупки менее напряженным.

Первый предпринятый многими сетевыми супермаркетами шаг-коммуникационные материалы в форме плакатов и звуковых сообщений о регулярной санитарной обработке торговых помещений.

Эксперименты показывают, что эффективны и другие меры. Например, дружелюбные, хорошо обученные консультанты создают в магазине

Small positive signs in the consumers' dual-front crisis / Доступно по ссылке: https://www2.deloitte.com/us/en/insights/ industry/retail-distribution/consumer-behavior-trends-state-ofthe-consumer-tracker/covid-19-recovery.html комфортную атмосферу и поддерживают доверие покупателей.

Мы прогнозируем тотальное изменение упаковки товаров. Во-первых, переход многих товаров на онлайн-полки интернет-магазинов кардинальным образом меняет роль упаковки в процессе выбора товара: ее нельзя потрогать и даже сколь-либо точно определить ее размер. Производители продуктов со временем станут отказываться от шелф-тестов и станут проводить новые эксперименты, отслеживая важность для покупателей качества и эксклюзивности упаковки товара в интернет-магазине.

Во-вторых, актуализируется одна из второстепенных функций упаковки - защитная. Потребители сегодня не уверены, в какой степени коронавирус может представлять опасность, оседая на поверхностях продуктов. В результате предпочтение будет отдаваться упакованным продуктам. При этом в ситуации сокращения времени нахождения в магазине, покупатели будут принимать решение о покупке быстрее - поэтому упаковка должна позволять идентифицировать продукт и его положительные свойства с первого взгляда. Если товар не будет распознан сразу, он, скорее всего, не будет куплен. 


\section{РАЗУМНОЕ ПОТРЕБЛЕНИЕ- ЭГОЦЕНТРИЧНОЕ ПОТРЕБЛЕНИЕ}

Пандемия заставила потребителей переоценить свои жизненные приоритеты. Новые ценности изменят и структуру расходов россиян. Разумеется, с учетом общего сокращения потребительских расходов. Тем не менее, мы ожидаем, что изменения потребительского поведения произойдут, главным образом, за счет приоритизации ценностей здоровья, семьи и цифровых технологий. Сильно снизится демонстративное потребление.

\begin{tabular}{lll} 
Гипотеза & Краткосрочный прогноз (1-3 года) & Среднесрочный прогноз (5-7 лет) \\
\hline Покупки станут более & Снижение доходов сократит число & Рационализация покупательского \\
рациональными & импульсных покупок. При этом & поведения будет снижаться одновременно \\
& главными критериями выбора & с ростом доходов россиян. При этом будет \\
в ближайшие годы останутся & происходить медленное возвращение \\
потребительские свойства продукта & к экоориентированному потреблению \\
и его безопасность для здоровья & и потреблению продуктов многоразового \\
& использования
\end{tabular}

Несмотря на то, что в России опасения в обществе по поводу коронавируса не так ярко выражены, как в большинстве других развивающихся стран, в первые месяцы после пандемии останутся опасения заразиться коронавирусом, поэтому в офлайне будет больше запланированных и меньше импульсных покупок.

Кроме того, актуализация ценности здоровья заставит россиян задуматься над качеством продуктов (особенно продовольственных товаров). В этой области изменение потребления в последние годы было продиктовано глобальной тенденцией перехода на экологически-ориентированное поведение. В текущих условиях эта тенденция скорректируется и будет проявляться в выборе натуральных, органических продуктов, а не защите экологии (экопроизводстве, экоупаковке и пр.), как это было ранее. Это же проявится и в сегменте непродовольственных (например, бытовых) товаров. Уже в период пандемии можно было наблюдать изменения коммуникационной политики крупных брендов, подчеркивавших приоритет здоровья человека.

Однако уход от идеи защиты экологии будет происходить не только в сторону «чистого» потребления. Мы прогнозируем, что в перспективе 5-7 лет в России вектор устойчивого развития сменится с защиты окружающей среды на достижение конкретных социальных и экономических целей (благодаря экологобезопасному поведению производителей и потребителей). Индустрии красоты, здоровья и моды увидят интерес покупателей к продукции небольших локальных производителей за счет их особой культурной идентичности, прозрачности, безопасности и «близости» к потребителю. Пока же россияне не готовы переплачивать за это, отдавая предпочтение качеству продуктов и качеству обслуживания.

Исследование НАФИ, проведенное в апреле 2020 года среди покупателей интернет-магазинов, показало, что для большинства россиян сервис играет очень весомую роль в выборе места покупки товара даже онлайн: 74\% покупателей готовы платить за товар больше, если это гарантирует высокое качество обслуживания. По результатам этого же исследования, 56\% интернет-покупателей готовы приобретать товар дороже, если он будет более экологичным и натуральным²8.

\footnotetext{
Пресс-релиз НАФИ от 26.05.2020 «Россияне привыкли к онлайн-покупкам и готовы переплачивать» / Доступно по ссылке: https://nafi.ru/analytics/rossiyane-privykli-k-onlaynpokupkam-i-gotovy-pereplachivat/
} 


\section{ВНИМАНИЕ К ЗДОРОВЬЮ И ФИЗИЧЕСКОЙ ФОРМЕ}

Понимание здорового образа жизни и отношение к физической форме меняются с появлением новых тенденций в сфере здравоохранения и питания, в связи с чем формируются определенные эталоны поведения. Один из главных трендов - это смещение восприятия здоровья от исключительно физического самочувствия и физической формы к стрессоустойчивости и эмоциональной стабильности. Такой подход приводит к еще большей коммерциализации понятий «счастья» и «благополучия».

По данным исследования рынка Euromonitor International на 2020 год, за последние пару лет понимание здорового образа жизни изменилось. Независимо от возраста люди стали отмечать важность для поддержания здоровья таких составляющих, как психическое благополучие, хорошее самочувствие, полноценный сон, поддержание хорошей физической формы, эмоциональное благополучие и отсутствие болезней ${ }^{29}$.

Топ-5 значений, которые люди вкладывают

в здоровый образ жизни, в \%

\section{Поколение Z Миллениалы Y Поколение X Бэби-бумеры}

психическое

благополучие

$61 \% \quad 64 \%$

$66 \%$

$66 \%$

хорошее

самочувствие

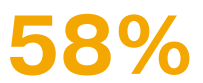

$61 \%$

$61 \%$

$64 \%$ полноценный сон

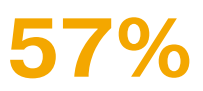

$59 \%$

$61 \%$

$63 \%$

5


По данным Аналитического центра НАФИ каждый четвертый опрошенный в период самоизоляции занимался спортом. Среди тех, кто занимался спортом ранее, 36\% продолжили уделять этому столько же времени, а 32\% отметили, что на самоизоляции они уделяли спорту больше времени ${ }^{31}$.

\section{«Чем из перечисленного вы занимаетесь}

в период самоизоляции?»*

в \% от всех опрошенных

Выполняете домашние дела

Продолжаете работать

Занимаетесь саморазвитием, проходите обучение

Отдыхаете, развлекаетесь

Занимаетесь спортом

Занимаетесь детьми

Другое

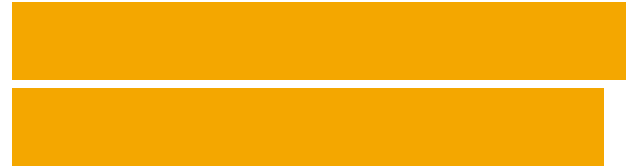

$36 \%$

\section{$31 \%$}

$26 \%$

$22 \%$

$11 \%$

$54 \%$

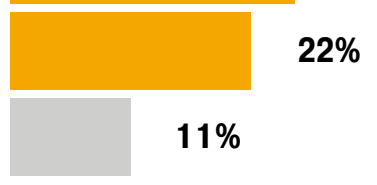

* Сумма ответов превышает 100\%, так как респонденты могли выбрать несколько вариантов ответа

Источник: опрос интернет-пользователей старше 18 лет, n=1009, НАФИ, апрель-май 2020 года

«Как изменилось количество времени, которое вы тратите на перечисленные ниже занятия?

\section{Вы стали уделять им больше или меньше времени?»}

в \% от тех, кто занимается спортом

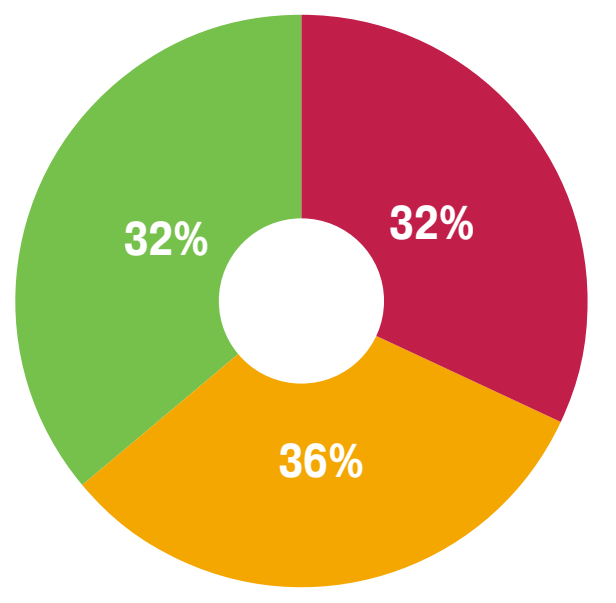

Стали уделять меньше времени

Уделяете столько же времени, как и ранее

Стали уделять больше времени 
«Занимаюсь гимнастикой постоянно: приседания, наклоны, работа с гантелями, бег на месте, отжимания. Это всегда хорошо. Еженедельно - баня, это традиция» [руководитель строительной компании, мужчина, 55 лет, Москва]
Больше половины опрошенных (55\%) отмечают, что после снятия ограничений самозоляции продолжат заниматься самостоятельно и не будут посещать тренажерный зал.

\section{«Будете ли вы продолжать заниматься спортом}

\section{самостоятельно или вернетесь в тренажерный зал}

после отмены режима самоизоляции?», в \%

Продолжу заниматься спортом самостоятельно и не буду посещать тренажерный зал

Буду заниматься больше самостоятельно, но частично продолжу посещать тренажерный зал

Буду снова посещать тренажерный зал и изредка заниматься спортом самостоятельно

Вернусь в тренажерный зал и забуду про самостоятльные тренировки

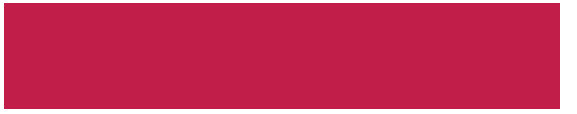

$55 \%$

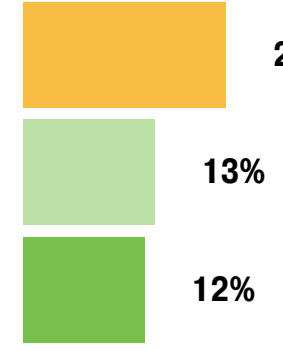

«В ближайшие полгода не пойду в тренажерный зал. На карантине я открыла для себя наиболее подходящий метод тренировок, и буду делать упор на них. Раньше я хотела пойти на танцы, но во все эти заведения, чисто психологически, я не смогу пойти в течение полугода» [студентка, 23 года, Москва]
Таким образом, пандемия еще раз подтвердила, что те граждане, которые хотят заниматься спортом, ищут возможности для этого и находят.

4 из 10 россиян отмечают, что во время самоизоляции их физическая форма ухудшилась.

\section{«Как изменилась ваша физическая форма}

за время самоизоляции?», в\%

Улучшилась

Не изменилась

Ухудшилась

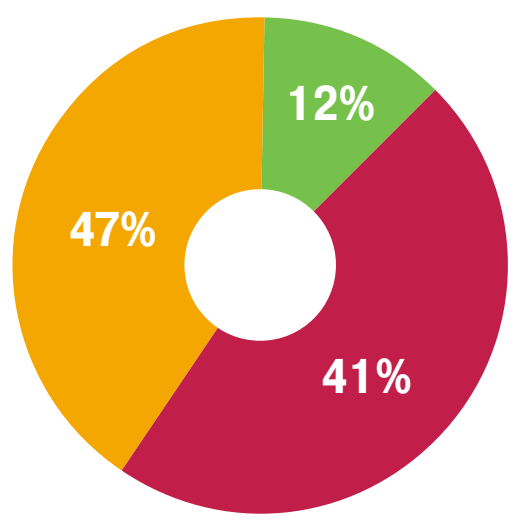


«Я заметила, что самоизоляция, с одной стороны, призвана спасать наше здоровье, а с другой стороны, она же и подрывает наше здоровье, потому что я в жизни столько дома не сидела, как за последние три месяца. Я физически отвыкла передвигаться, как раньше. И мне уже реально тяжело пройти две остановки. Если бы это затянулось на большее время, я не знаю, к чему бы это привело» [студентка, 23 года, Москва]

Традиционные методы похудения являются приоритетными для всех поколений. Тем не менее, по данным исследования рынка Euromonitor International, миллениалы и поколение Z более склонны к увеличению потребления воды и физических упражненийз2. Эти два поколения ориентированы не только на поддержание здорового веса, но, что более важно, стремятся быть физически здоровыми и сильными. В свою очередь, бэби-бумеры с большей вероятностью вносят изменения в свой рацион, такие как сокращение потребления сахара или употребление меньшего количества пищи в целом, прежде чем увеличивать количество упражнений.

\title{
Топ-5 предпринимаемых действий для снижения веса
}

в \% от представителей разных поколений, которые в настоящее время пытаются похудеть

\section{Поколение Z Миллениалы (Y) Поколение X Бэби-бумеры}

$1 \begin{gathered}\substack{\text { стараются пить } \\ \text { больше воды }} \\ 59 \%\end{gathered}$

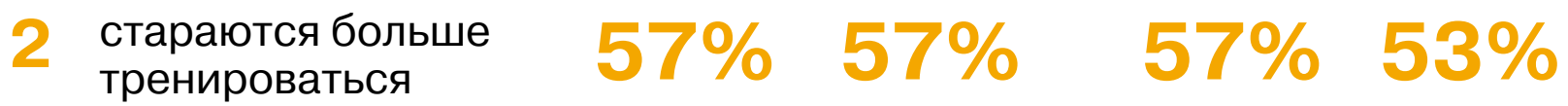

\section{$3 \begin{gathered}\text { стараются уменьшить } \\ \text { потребление сахара }\end{gathered}$}

\author{
4. стараются в целом \\ меньше есть
}

\section{$40 \% \quad 41 \%$}

\section{$5 \begin{gathered}\begin{array}{c}\text { стараются уменьшить } \\ \text { перекусы между }\end{array} \\ 39 \%\end{gathered}$ приемами пищи}




\section{ПРИГОТОВЛЕНИЕ пищи}

В результате закрытия кафе, ресторанов и других мест общественного питания приготовление пищи переместилось в дома. Во время самоизоляции у граждан сформировалась привычка есть дома, в кругу семьи.

Россияне стали отдавать предпочтение более качественным и полезным продуктам. По данным Всероссийского центра изучения общественного мнения, за своим питанием сегодня следят более половины россиян (60\%) $)^{33}$.

\section{«Следите ли вы за своим}

\section{питанием, соблюдаете}

\section{диету или нет?»}

в \% от всех опрошенных

Да, соблюдаю диету, которую рекомендовал врач

Да, соблюдаю самостоятельно выбранную диету

Да, стараюсь есть здоровую пищу

Ем, что хочу, здоровье меня не беспокоит

Думать о качестве пищи нет возможности, ем, что могу себе позволить

Затрудняюсь ответить других платить больше за такие продукты готовы люди с высоким уровнем дохода (39\%) и женщины (37\%) 34 .

В первое время после открытия заведений общественного питания многие будут остерегаться их посещения в целях досуга и предпочтут, скорее, ходить к близким в гости или же просто прогуливаться в парках. Исследование Аналитического центра НАФИ показало, что 63\% россиян будут продолжать избегать мест скопления людей, соблюдать дистанцию и меры предосторожности. Люди будут стараться не посещать общественные места в закрытых помещениях без крайней необходимости (80\%) и проводить как можно больше времени на открытом воздухе (87\%)

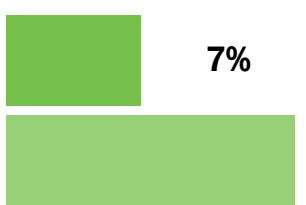

$15 \%$

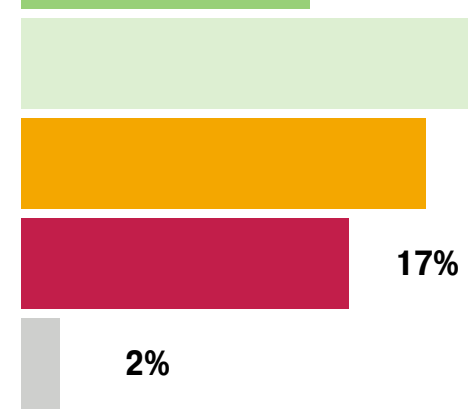

Источник: всероссийский опрос населения, n=1600, ВЦИОМ, июнь 2020 года

В пользу усиления внимания к качеству продуктов говорит и исследование НАФИ. К началу пандемии каждый третий россиянин (34\%) был готов переплачивать за товар, если на него будет нанесена государственная маркировка органического продукта, а сам продукт будет произведен без использования пестицидов и стимуляторов роста растений. Чаще 


\section{«Ниже приведены высказывания людей о планах на период} после отмены самоизоляции. Насколько вы согласны с каждым из них? После отмены режима самоизоляции...»

в \% от всех опрошенных

я буду продолжать избегать мест скопления людей, соблюдать дистанцию и меры предосторожности

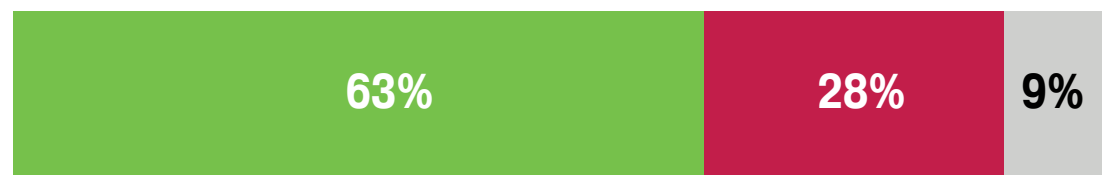

Я буду стараться не посещать общественные места в закрытых помещениях без крайней необходимости

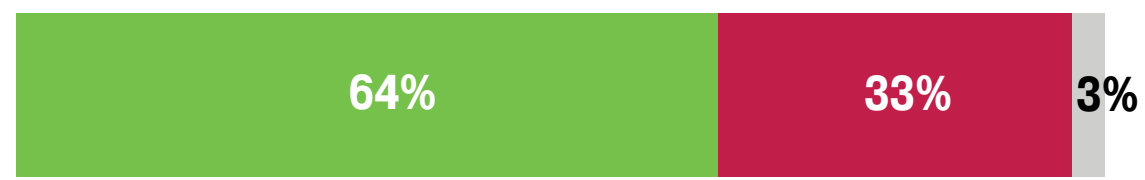

Я буду стараться проводить как можно больше времени на открытом воздухе

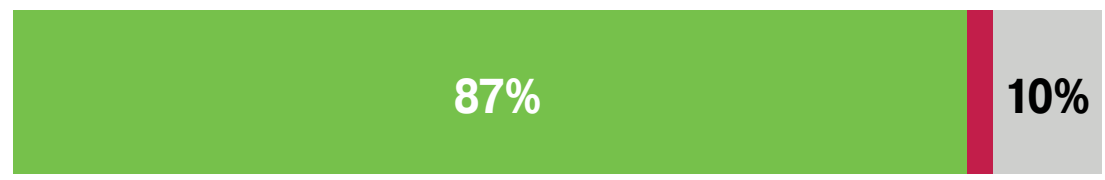

Согласен

Не согласен

Затрудняюсь ответить

Источник: опрос населения, n=500, НАФИ, июнь 2020 года

«На меня повлияла эта ситуация с психологической точки зрения, я стараюсь дворами обходить толпы людей. Я не смогу пойти в ближайший год в кинотеатры, если их откроют, не смогу пойти в кафе и сидеть там. Я молчу уже про концерты, фестивали, крупные массовые мероприятия. С психологической точки зрения это сильно меня подкосило» [студентка, 23 года, Москва]

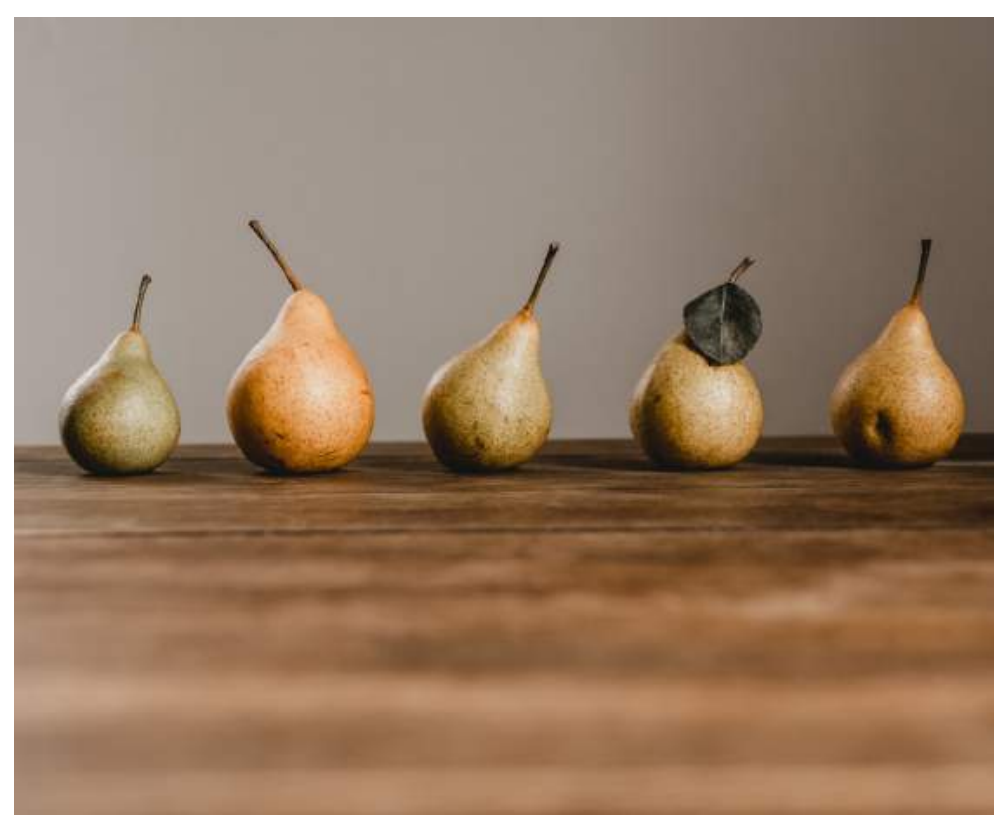




\section{ЭМОЦИОНАЛЬНОЕ СОСТОЯНИЕ}

$\begin{array}{lll}\text { Гипотеза } & \text { Краткосрочный прогноз (1-3 года) } & \text { Среднесрочный прогноз (5-7 лет) } \\ \text { В период самоизоляции } & \text { Акцент на психическое благополучие } & \text { Возрастет спрос на дистанционные сеансы } \\ \text { выросло число людей } & \text { будет продолжать расти ускоренными } & \text { психотерапии. Цифровые и технологичные } \\ \text { с депрессией } & \text { темпами. Возрастет спрос } & \text { решения для самообслуживания приобретают } \\ & \text { на алкоголь и безрецептурные } & \text { все большее значение в профилактике здоровья } \\ & \text { успокоительные препараты } & \text { наряду с препаратами, укрепляющими иммунитет } \\ & & \text { и снимающими стресс }\end{array}$

В период самоизоляции и пандемии возросло количество людей, страдающих депрессией, граждане чаще стали испытывать страх. Самоизоляция привела к нарушению привычного распорядка дня, негативные новости воспринимались более остро, чем обычно, былые страхи проснулись, возобновились приступы раздражительности, уныния, тоски, что привело к усугублению депрессивных состояний.

\section{В такие моменты профессиональная поддержка} важна как никогда. Так, в Москве за период с начала марта до середины мая на телефон неотложной психологической помощи поступило на 13\% больше обращений, чем в прошлом году ${ }^{35}$.
«Я за собой заметила такой момент, что у меня выработалась паранойя. Я под дождь попала несколько дней назад, и вчера у меня запершило в горле и поднялась температура 37. И тут у меня появилось чувство страха, сейчас уже все нормально» [студентка, 23 года, Москва]

Половина опрошенных (54\%) в условиях самоизоляции испытывают стресс, тревогу, беспокойство, 33\% из них испытывают стресс больше обычного, и еще 9\% испытывают значительно более сильный стресс.

\section{«Некоторые люди в условиях самоизоляции испытывают}

стресс, беспокойство, тревогу. А вы лично ощущаете

в период самоизоляции стресс больше обычного?»

в \% от всех опрошенных

Да, испытываете значительно более сильный стресс

Испытываете стресс немного больше обычного

Испытываете стресс, но меньше, чем обычно

Почти не испытываете стресс
$9 \%$

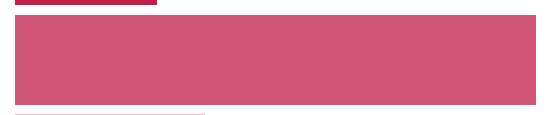

$34 \%$ 
Чаще всего причинами стресса, беспокойства являлись тревога перед неопределенностью будущего (66\%), отсутствие свободы передвижения (50\%), волнение за свое здоровье и здоровье близких (42\%), страх потерять свой бизнес, обанкротиться (29\%), страх потерять работу, остаться без доходов (27\%).

\section{«С чем больше всего связаны ваш стресс, беспокойство, тревога?»}

в \% от всех опрошенных

\author{
Тревога перед неопределенностью будущего \\ Отсутствие свободы передвижения \\ Волнуюсь за свое здоровье и здоровье близких \\ Страх потерять свой бизнес, обанкротиться \\ Страх потерять работу, остаться без доходов
}

Другое

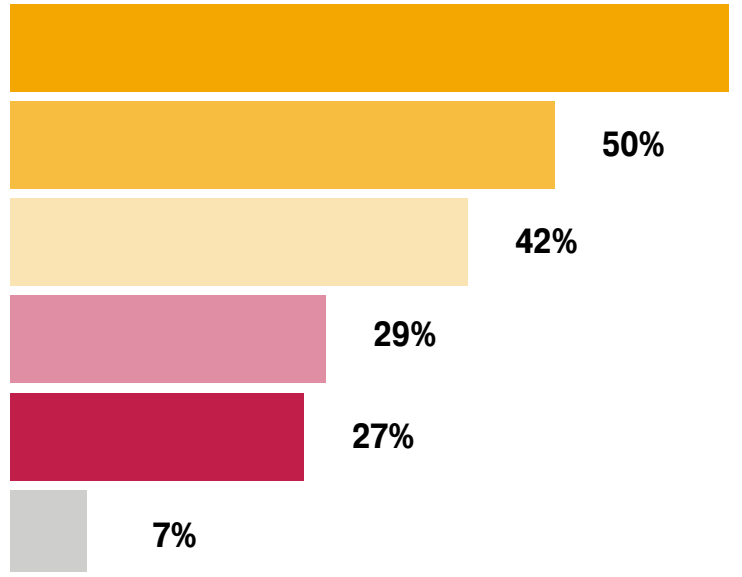

$66 \%$
Источник: опрос населения, n=680, НАФИ, апрель 2020 года

\begin{abstract}
«Бывают такие моменты, что тревогу чувствуешь, когда видишь, что у компаньонов не все ладится, у больших организаций не все ладится. Задержки оплаты, даже у таких крупных предприятий» [руководитель строительной компании, мужчина, 55 лет, Москва]

Пандемия коронавируса еще раз напомнила, что здоровье является ценностью высшего порядка - не только для себя, но и для близких. Эксперты предполагают, что проблемы, связанные с расстройством психики из-за последствий самоизоляции, проявятся гораздо позже.
\end{abstract}

В ближайшее время возрастет спрос на дистанционные сеансы психотерапии, которыми многие уже начали пользоваться, находясь дома. Во время самоизоляции видеозвонки стали необходимым и своевременным средством, в том числе и в медицине. 


\section{УХОД ЗА ВНЕШНОСТЬЮ \\ И ВЕАUTY-ИНДУСТРИЯ}

$\begin{array}{lll}\text { Гипотеза } & \text { Краткосрочный прогноз (1-3 года) } & \text { Среднесрочный прогноз (5-7 лет) } \\ \text { Люди привыкли многие процедуры } & \text { В связи с дополнительными } & \text { В среднесрочной перспективе- } \\ \text { делать сами и в первое время будут } & \text { издержками салонов красоты } & \text { рост спроса на beauty-процедуры } \\ \text { экономить } & \text { возрастут цены на bеauty-процедуры, } & \text { с выездом на дом упроверенных } \\ & \text { многие люди будут вынуждены } & \text { мастеров } \\ & \text { отказаться от посещения салонов } & \\ \text { красоты в связи со сложным } & \\ \text { финансовым положением } & \end{array}$

Изменились привычки ухода за собой, многие привыкли делать beauty-процедуры самостоятельно.

«Я ухаживаю за волосами часто, посещаю салоны. Сейчас сформировала привычку покупать все средства себе самостоятельно» [руководитель компании, женщина, 34 года, Уфа]

По данным GfK, находясь на изоляции, люди больше всего хотят повидаться с друзьями и родственниками (50\%). На втором месте по популярности - парикмахер/косметолог (40\%). Каждый третий мечтает пойти в магазин одежды и торговый центр ${ }^{36}$.

Открытие салона после пандемии требует дополнительных затрат: необходимо обеспечить заведение лампами для дезинфекции, масками, перчатками, халатами, термометрами. В связи с этими издержками возрастут и цены на beauty-процедуры.
«Введение мер безопасности в салонах - сложный момент, потому что, во-первых, это достаточно дорого. Мы просчитывали: меры безопасности нам будут обходиться в 5000 рублей в день на каждый салон. К тому же, когда мы оправимся, у нас не будет возможности принимать людей в том объеме, в котором мы это делали раньше»,- отмечает Ксения Шипилова, основательница сети салонов красоты Keеp looking ${ }^{37}$.

По данным исследования, проведенного Аналитическим центром НАФИ, большинство опрошенных (78\%) после снятия ограничений самоизоляции планируют посещать парикмахерские и салоны красоты с такой же частотой, как и до пандемии.

\footnotetext{
Пресс-релиз GfK от 02.06.2020 «Социальное взаимодействие и покупки после завершения самоизоляции» / Доступно по ссылке: https://www.gfk. com/ru/press/Gfk-Study-Socializing-and-Shopping-After-SelfIsolation?hsLang=ru
}

\footnotetext{
«Запретный маникюр: хозяйки салонов красоты об убытках из-за простоя, подпольной работе и ценах после пандемии» / Доступно по ссылке: https://www.forbes.ru/ forbeslife/400661-zapretnyy-manikyur-hozyayki-salonov-krasotyob-ubytkah-iz-za-prostoya-podpolnoy
} 


\section{«Во время самоизоляции в большинстве регионов}

\section{России парикмахерские}

и салоны красоты были

закрыты. После снятия

карантина вы будете

посещать таких специалистов

чаще, реже или так же,

\section{как и до пандемии?»}

в \% от всех опрошенных

Источник: опрос населения, n=500, НАФИ, июнь 2020 года

«Я попыталась делать маникюр самостоятельно, но тут менее успешно, чем со спортом, все тщетно. Я жду момента, когда можно будет пойти в салон. Нахожусь сейчас не в Москве, в Москве я бы точно не пошла» [студентка, 23 года, Москва]

После отмены ограничений самоизоляции в салонах красоты все выглядит несколько иначе, чем прежде: на входе установлены бесконтактные термометры и санитайзеры, мастер - в маске, расстояние между клиентами не меньше 1,5 м, все контактные поверхности салона и инструменты мастера обрабатываются после обслуживания клиента.

Но клиентов, судя по всему, новые правила не беспокоят - во многих парикмахерских все расписано на недели вперед, по словам Алины Швец, сооснователя сети городских парикмахерский Mute $^{38}$.
«В Москве открылись салоны красоты и парикмахерские»: фоторепортаж / Доступно по ссылке: https://www.forbes. ru/forbeslife-photogallery/402583-v-moskve-otkrylis-salonykrasoty-i-parikmaherskie-fotoreportazh?photo=7

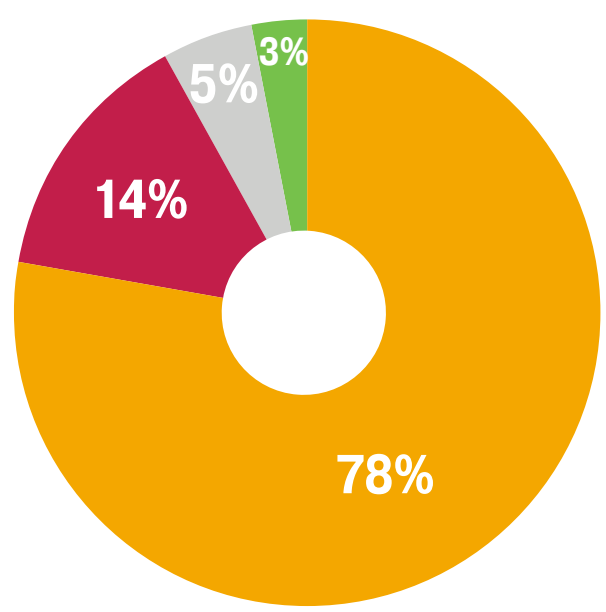

Чаще

Реже

Так же

Затрудняюсь ответить

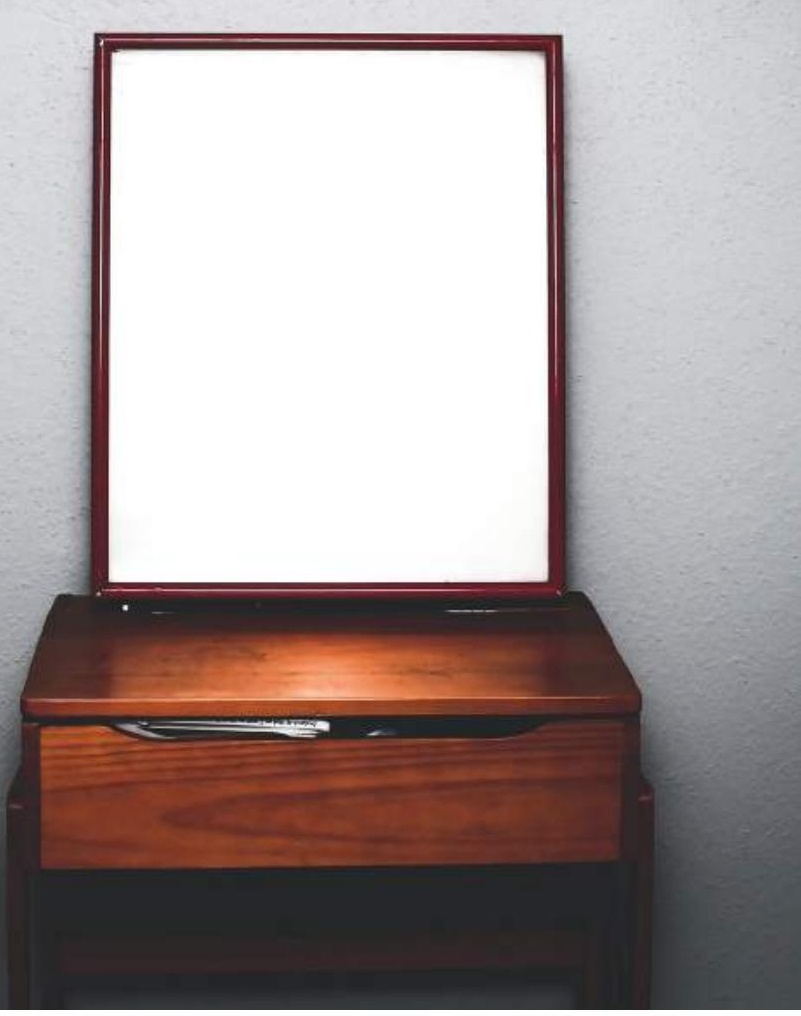




\section{УЛУЧШЕНИЕ \\ жилищных Условий}

\begin{tabular}{|c|c|c|}
\hline Гипотеза & Краткосрочный прогноз (1-3 года) & Среднесрочный прогноз (5-7 лет) \\
\hline $\begin{array}{l}\text { В период самоизоляции многие } \\
\text { отложили улучшение жилищных } \\
\text { условий }\end{array}$ & $\begin{array}{l}\text { Рост спроса на мебель и товары } \\
\text { для интерьера. С учетом летнего } \\
\text { сезона-также на стройматериалы } \\
\text { и продукцию DIY }\end{array}$ & $\begin{array}{l}\text { В среднесрочной перспективе } \\
\text { возрастет спрос на покупку } \\
\text { загородных участков /домов }\end{array}$ \\
\hline
\end{tabular}

Во время самоизоляции 71\% россиян находились в городских квартирах, а четверть (24\%) - в частных домах, на даче.

\section{«После введения режима}

самоизоляции люди

должны были больше, чем

обычно проводить времени

дома. А где вы находились

$$
\text { большую часть времени }
$$

в период самоизоляции?»

в \% от всех опрошенных

Источник: опрос населения, n=500, НАФИ, июнь 2020 года

В условиях экономического кризиса многие россияне отложили непредвиденные расходы на тот момент, когда ограничения самоизоляции будут отменены и их финансовая ситуация улучшится, в том числе это относится и к расходам на ремонт.

«Может быть, и захотелось что-то поменять, но режим экономии в данной ситуации присутствует. Поэтому ничего не предпринимаем, наслаждаемся природой и выращиваем урожай» [руководитель строительной компании, мужчина, 55 лет, Москва]

По данным исследования, проведенного Аналитическим центром НАФИ, треть россиян оценивают свое жилье как некомфортное и после снятия карантина все-таки собираются предпринять действия для улучшения своих жилищных условий.

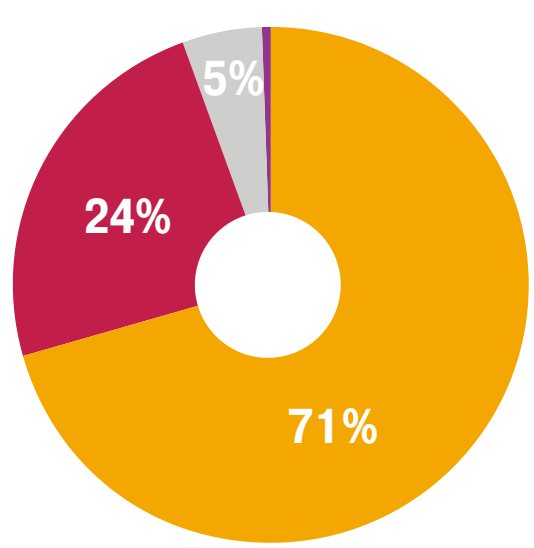

В своей или съемной квартире

В доме/на даче
В доме, арендованном на время самоизоляции

Другое
Чаще всего планируют сделать ремонт или перепланировку (39\%), приобрести мебель, предметы декора (39\%), переехать в другое жилье (18\%) или купить или построить другое жилье (4\%) 


\section{«После снятия карантина, собираетесь ли вы предпринять} что-либо для улучшения условий, в которых вы живете, или нет?»

в \% от тех, кто собирается что-либо предпринять для улучшения жилищных условий

Собираетесь купить или построить другое жилье

Собираетесь переехать в другое жилье

Собираетесь приобрести мебель, предметы декора

Собираетесь сделать ремонт или перепланировку
$4 \%$

\section{$18 \%$}

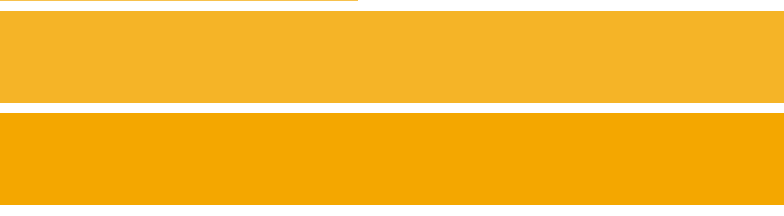

\section{ОТНОШЕНИЯ В СЕМЬЕ}

Во время самоизоляции усилилось чувство общности. Недели и месяцы множество семей жили, много общаясь друг с другом, решая множество неизбежно возникающих при этом серьезных проблем.
«Это хорошо, что мы все вместе находимся, хоть друг друга видим. Бывает, ругаемся, повышаем голос с женой друг на друга. Все нормально - это семейная жизнь, никуда не денешься от этого» [руководитель строительной компании, мужчина, 55 лет, Москва]

$\begin{array}{lll}\text { Гипотеза } & \text { Краткосрочный прогноз (1-3 года) } & \text { Среднесрочный прогноз (5-7 лет) } \\ \text { В период самоизоляции под } & \text { Родители будут больше времени } & \text { Чаще начнут привлекать } \\ \text { напряжением оказались не только } & \text { проводить с детьми, чаще устраивать } & \text { родственников и частный персонал } \\ \text { отношения между супругами (что } & \text { совместный отдых. } & \text { для помощи с детьми. } \\ \text { не приведет к массовым разводам), } & \text { Повышение ценности семьи, } & \text { Развитие детских учреждений } \\ \text { но также между родителями и детьми, } & \text { укрепление межпоколенческих связей } & \text { (развивающие кружки, курсы, } \\ \text { которых приходилось чем-то занимать } & & \text { спортивные секции) }\end{array}$

Однако каждый человек по-разному реагирует на стресс и испытания, связанные с вынужденным, почти круглосуточным общежитием. Во многих семьях возникали трудности в период самоизоляции из-за совмещения работы, учебы и отдыха в одном месте и отношения с другими членами семьи становились напряженными. 


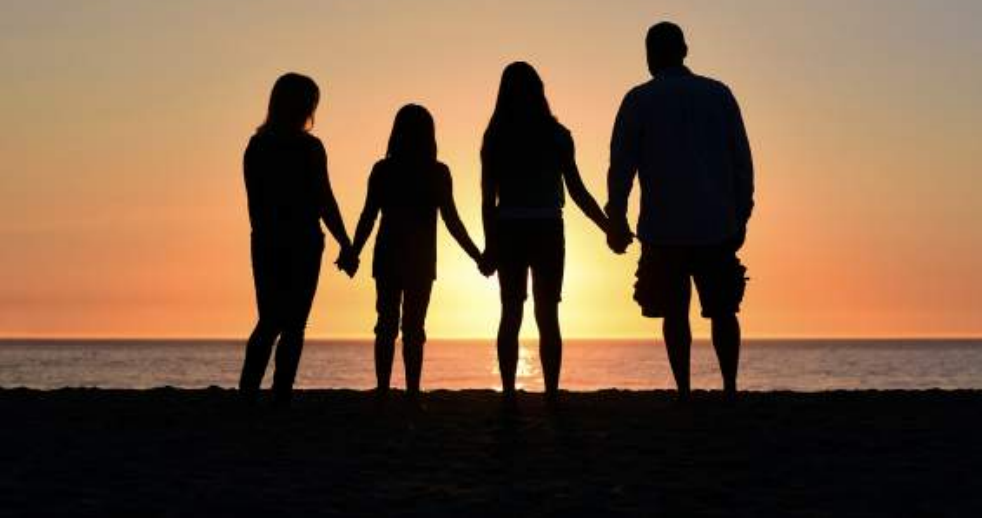

«Классно, когда дети были в садике. Сейчас они дома - ну и дома, ну и хорошо. Сложно тем, у кого дети в школе, кто не умеет детей отпускать и тем, кому надо, чтобы они хорошо учились. Тогда всем сложно» [спортивный тренер, женщина, 32 года, Москва]

По словам Уполномоченного по правам человека Татьяны Москальковой, в период пандемии отмечен рост случаев домашнего насилия в 2,5 раза $^{39}$. Такая же тенденция фиксируется по всем странам, где вводилась самоизоляция: во Франции число случаев насилия увеличилось на 30\%, в Китае - вдвое, Бразилия также фиксирует рост показателей.
Самоизоляция стала испытанием и для родителей, которым пришлось успевать выполнять свои рабочие обязанности, но и также занимать своих детей.

«Большинство австрийских женщин на первое место ставят семью, а только потом - профессиональную реализацию. Уменя получалось совмещать эти два приоритета. Моей дочке в июне исполнится три года, и мне кажется, она не страдает от того, что много времени проводит только со мной. Карантин - больше испытание для родителей, чем для детей. В соцсетях я видела много роликов и шуток среди российских мам о том, как им непросто на карантине, как они теперь понимают учителей» [домохозяйка, женщина, 40 лет, Вена]

«Естественно, стали больше общаться, ребенок учился в онлайне, с ним сидела жена, ей было тяжеловато, но уже все нормально» [рабочий песчаного карьера, мужчина, 59 лет, Балаклава (Крым)]

По данным Аналитического центра НАФИ, большинство опрошенных отмечают, что отношения с другими членами семьи в период самоизоляции не изменились. И все же есть те, кто отмечает ухудшение отношений с другими членами семьи. Чаще говорят об ухудшении отношений с супругом/супругой (18\%), с ребенком/детьми (10\%), с родителями (5\%).

\section{«Как изменились ваши взаимоотношения с членами вашей семьи за период самоизоляции?»}

в \% от всех опрошенных

С супругом/партнером

С ребенком/детьми

С родителями

\section{$6 \%$} $13 \%$ $77 \%$ $10 \%$

Отношения улучшились

Отношения ухудшились

Отношения остались такими же, как и были до этого

Источник: опрос населения, n=500, НАФИ, июнь 2020 года 
Таким образом, отношения супругов, которые и до пандемии были непростыми, обострились и ухудшились, в основном же семьи укрепились. Наилучшим образом ситуация выглядит в отношениях с пожилыми родителями, с которыми в обычное время люди не общались настолько часто и плотно. Можно утверждать, что это позволило укрепить межпоколенческие семейные связи и повысило ценность семьи в российском обществе.

\section{ОБЩЕСТВЕННАЯ СОЛИДАРНОСТЬ, ВЗАИМОПОМОЩЬ И ВОЛОНТЕРСТВО}

$\begin{array}{lll}\text { Гипотеза } & \text { Краткосрочный прогноз (1-3 года) } & \text { Среднесрочный прогноз (5-7 лет) } \\ \text { Волонтерское движение не развивается } & \text { В общении больше будут цениться } & \text { Общественный запрос на социальный } \\ \text { даже во времена, когда на такую } & \text { чувство ответственности, } & \text { бизнес и социальные НКО, } \\ \text { деятельность есть спрос } & \text { возможность положиться на человека, } & \text { на государственную социальную } \\ & \text { его готовность помочь. } & \text { политику } \\ & \text { Рост значимости социальной работы } \\ & \text { как профессии, улучшение отношения } \\ & \text { в обществе к соцработникам } & \\ \end{array}$

В период самоизоляции особенно в помощи нуждались незащищенные слои населения - пожилые, которые не могли купить себе товары первой необходимости и медикаменты.

Почти четверть (23\%) россиян отметили, что в период самоизоляции помогали другим и занимались благотворительностью ${ }^{40}$. Чаще всего помогали знакомым пожилым либо нуждающимся в помощи, покупая продукты или выгуливая питомцев, реже работали волонтерами и помогали врачам в медучреждениях. Женщины безвозмездно помогали окружающим чаще мужчин, а жители столиц чаще, чем в среднем по России.

\section{«Приходилось ли вам в период самоизоляции помогать}

\section{безвозмездно другим людям, не являющимся}

членами вашей семьи, следующим образом?»

в \% от всех опрошенных

\begin{abstract}
Помогать знакомым пожилым людям, либо людям, нуждающимся в помощи, принести продукты, выгулять собаку

Проводить бесплатные тренинги, лекции, мастер-классы онлайн

Участвовать во флешмобе, например, \#спасибоврачам
\end{abstract}

Другое

Нет, не приходилось

\section{$14 \%$}

$4 \%$

$3 \%$

$2 \%$
Источник: опрос интернет-пользователей старше 18 лет, НАФИ,

апрель-май 2020 года
Пресс-релиз НАФИ от 20.05.20 «Россияне

на самоизоляции: соцсети, спорт и компьютерные игры» / Доступно по ссылке: https://nafi.ru/analytics/rossiyane-nasamoizolyatsii-sotsseti-sport-i-kompyuternye-igry/ 


\section{В СФЕРЕ КУЛЬТУРЫ,}

\section{ОБРАЗОВАНИЯ}

\section{И САМОРАЗВИТИЯ}

В период эпидемии культурная и развлекательная сфера жизни подверглись значительной степени виртуализации. Критическое сужение границ реальности в условиях самоизоляции дало импульс к расширению границы виртуального, нематериального мира, где людям стали доступны суррогатные версии коммуникации, приобщение к культуре, получение образования и т. д. Ситуация, в которой интернет стал главной развлекательной и образовательной площадкой, предлагая пользователям получить реальные знания, эмоции и впечатления без реального присутствия, сформировала новые поведенческие практики и потребительские предпочтения, а также стала импульсом для перехода бизнеса в области культуры и образования на новые управленческие модели.

\section{САМОРАЗВИТИЕ И САМООБРАЗОВАНИЕ}

$\begin{array}{lll}\text { Гипотеза } & \text { Краткосрочный прогноз (1-3 года) } & \text { Среднесрочный прогноз (5-7 лет) } \\ \text { Многие посвятили время } & \text { Индустрия платного дополнительного } & \text { Платное дополнительное онлайн- } \\ \text { саморазвитию и стали } & \text { онлайн-образования продолжит } & \text { образование институциализируется } \\ \text { платить за это } & \text { развиваться и после завершения пандемии, } & \text { в отдельную отрасль, которая начнет } \\ & \text { давая возможность к профессиональной } & \text { конкурировать с традиционным } \\ \text { самореализации и переквалификации } & \text { образованием } \\ & \text { специалистов, потерявших работу во время } & \\ \text { кризиса или желающих обезопасить себя } & \\ \text { в будущем через приобретение профессий, } & \text { которыми можно заниматься в удаленном } \\ & \text { онлайн-режиме }\end{array}$

Для многих россиян период самоизоляции стал шансом наверстать упущенное в личном образовании. Блокировка ряда социальных и образовательных возможностей создала потенциал для развития других, ранее не востребованных или недостаточно освоенных. Курсы, научные подкасты и различные марафоны по саморазвитию, на которые раньше не хватало времени, приобрели значительную актуальность и популярность.
Результаты исследования, проведенного Аналитическим центром НАФИ в мае 2020 года, подтверждают этот факт. Каждый третий россиянин на самоизоляции занимался учебой или саморазвитием (36\%). Обучению больше других посвящают время молодые россияне 18-24 лет (59\% против 36\% в среднем по стране) - группа населения с наиболее экономически активным поведением, для которой свойственны высокий уровень адаптации и обучаемости. Чаще всего на самоизоляции изучали иностранные языки, на втором месте - чтение книг 
и повышение цифровых компетенций (программирование/пользование специальными программами или сервисами)

Активное чтение книг во время самоизоляции (27\% россиян стали больше читать) было мотивировано не только тягой к саморазвитию, но и возможностью отвлечься от негативного новостного фона и в целом происходящего вокруг.

Анализ ответов респондентов, полученных в ходе проведенного Аналитическим центром НАФИ качественного исследования, показывает, что россияне, которые были вынуждены перейти на удаленный формат работы, предпочитают углублять знания в своей профессиональной сфере, осваивать новые дисциплины и интеллектуальное творчество. В то время как те, кто уже и раньше практиковал удаленку, теперь нашли время для чтения интересных книг и публицистики, а не только профессиональной литературы.

«Я поставила себе задачу вспомнить английский. Теперь читаю документы по работе и аналитику на английском. Раньше я так не поступала, теперь могу» [руководитель компании, женщина, 34 года, $\mathrm{y} \phi \mathrm{a}$

«Я осваиваю курсы по проектному менеджменту, готовлюсь к сертификации на проджект-менеджера международного уровня. Помимо этого, разработала собственный курс по цифровому пиару и планирую его запускать» [специалист в сфере digital-pr, женщина, 33 года, Женева]
«Сейчас читаю больше публицистики, а не профессиональной литературы. Перешел на бумажные книги» [консультант-аналитик, мужчина, 41 год, Вашингтон]

В ответ на стремительный рост спроса на образовательные услуги, число предложений соответствующих сервисов заметено возросло и трансформировалось с учетом текущей обстановки. Решение задачи по привлечению и удержанию клиентов медийные и образовательные онлайн-сервисы реализовывали с помощью значительных скидок или полного бесплатного доступа (особенно в первые недели эпидемии), создания уникального контента, оптимизации бизнес-процессов через новый для многих опыт перехода из офлайна в Сеть (университеты, библиотеки).

Получило широкое распространение самообразование и среди предпринимателей, руководителей бизнеса, которые как никто другой должны были эффективно адаптироваться в кризисной ситуации. Исследование Аналитического центра НАФИ, проведенное для университета «Синергия», подробно иллюстрирует эту тенденцию.

Согласно полученным данным, именно среди представителей бизнеса обозначился наиболее заметный тренд к получению новых знаний и навыков. Безусловно, это вызвано условиями, в которых выживание компании зависит от наличия способной эффективно адаптироваться к реалиям бизнес-модели.

\section{«Одни люди используют время самоизоляции и нахождения}

на карантине для отдыха, другие, напротив, посвящают

его саморазвитию. Если говорить откровенно, как вы

в основном проводили/проводите время на самоизоляции?»

в \% от всех опрошенных

$\begin{array}{cccc}\text { Предприниматели } & 9 \% & 52 \% & 39 \% \\ \text { Наемные работники } & 7 \% & 45 \% & 48 \% \\ & & \\ \text { ом занимались домашними делами или отдыхали } & \\ \text { ом занимались саморазвитием, самообразованием } & \end{array}$


Именно поэтому руководителям сейчас понадобились дополнительные знания по повышению операционной эффективности бизнеса, маркетингу, снижению издержек, организации удаленной работы и способов заработать после пандемии. В то время как наемные работники чаще, чем бизнесмены предпочитали заниматься иностранными языками и психологией, то есть реализовывать более частные, личные интересы.

\section{«Удалось ли вам за период самоизоляции, карантина научиться чему-то новому, получить какие-то новые профессиональные знания?»}

в \% от тех, кто получал новые знания, проходил обучение

$\begin{array}{llc} & \text { Предприниматели } & \text { Наемные } \\ \text { Управление, менеджмент } & 55 \% & 51 \% \\ \text { Маркетинг, реклама } & 57 \% & 48 \% \\ \text { Продажи } & 49 \% & 40 \% \\ \text { Иностранные языки } & 20 \% & 27 \% \\ \text { Медицина, психология } & 18 \% & 25 \% \\ \text { Финансы, бухгалтерский учет } & 21 \% & 17 \% \\ \text { Компьютерные технологии, программирование } & 12 \% & 16 \% \\ \text { Дизайн } & 6 \% & 4 \% \\ \text { Другое } & 11 \% & 14 \%\end{array}$

Источник: всероссийский опрос населения, n=1600, НАФИ, май 2020 года

Согласно наблюдаемым тенденциям и сохранению условий экономического кризиса, можно предположить, что индустрия платного образования будет продолжать развиваться.

Анна Чащина, директор по маркетингу компании EdMarket предполагает, что в ближайшее время вырастет спрос на короткие курсы с невысокой ценой, от 15000 до 35000 рублей, так как многие не уверены, что смогут вернуться на прежнюю работу и для них остается актуальным получение новой специальности. Краткосрочные курсы будут продолжать превалировать над долгосрочными в силу высокой степени неопределенности кризисной ситуации и невозможности планировать будущее на длительный срок.
Занятие самообразованием в кризисных условиях пандемии отличалось значительным ростом. В большей мере люди фокусировались на получении практических знаний и навыков, которые могут облегчить выход из сложившейся непростой ситуации в плане трудоустройства, - освоении базовых знаний в профессиях, подразумевающих удаленный формат работы (программирование, SMM, вебдизайн), расширении знаний в областях, смежных или близких с нынешней профессией. Также обозначился тренд на получение более глубоких знаний в своей профессии с целью повысить собственную ценность как сотрудника и избежать сокращения с этим же фактом связано более частое прохождение полного курса, по окончании которого можно получить сертификат и предъявить его нынешнему или потенциальному работодателю. 
Столь высокая доля людей, занимавшихся самообразованием и личным развитием во время самоизоляции, может потенциально положительно сказаться на уровне выполнения трудовых задач после выхода из режима самоизоляции.

При этом, после выхода из эпидемии новые клиенты образовательных сервисов будут постепенно возвращаться к привычному образу жизни, и частота использования образовательных сервисов может снизиться. В этих реалиях руководителям, маркетологам и разработчикам важно за короткие сроки привязать людей к своим продуктам.

\section{КУльтУРныЙ досуг}

Виртуализация сферы досуга стала одним из главных феноменов периода пандемии коронавируса. музеи, театры, выставки - места, отличающиеся традиционной формой присутствия посетителей проявили поразительную степень адаптивности к текущим кризисным событиям и вернулись к своим ценителям через виртуальные туры и онлайн-трансляции. А привычные мультимедийные онлайн-сервисы предложили пользователям облегченные возможности для подписки и формируют контент, актуальный для нынешнего времени - развлекатель- ные подборки для всей семьи, кино и сериалы, которые пользователи могли пропустить раньше и т. д.

Если рассматривать подробнее специфику потребления развлекательного контента, то, по данным исследования Аналитического центра НАФИ, 40\% россиян на самоизоляции стали чаще смотреть фильмы и развлекательные передачи, треть (30\%)общаться в социальных сетях, 15\% - играть в компьютерные игры.

«Как изменилось количество времени, которое вы тратите на перечисленные ниже занятия? Вы стали уделять им больше или меньше времени?»

\% тех, кто стал уделять больше времени этим активностям

Просмотр фильмов, сериалов, развлекательных передач

Общение с друзьями и родственниками по телефону, интернету

Общение в социальных сетях

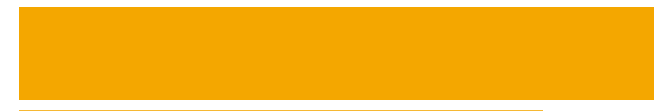

Чтение книг

Обучение (языки, программирование, психологические курсы, др.)

Занятия спортом

Компьютерные игры 
Помимо увеличения количества времени, затраченного на развлечения в Сети, возросли и траты на онлайн-досуг. Данные, полученные в результате исследования Mastercard, подтверждают этот факт почти каждый третий респондент в России (27\%) увеличил расходы в этой сфере ${ }^{42}$.

Онлайн-кинотеатры стали лидерами в сфере развлечений. По результатам исследования ASOdesk, соответствующие приложения впервые стали лидерами в категории «Развлечения» в AppStore, обогнав по популярности и спросу Facebook и Instagram ${ }^{43}$. «Кинопоиск» улучшил позиции на 150 пунктов, a Premier - на 250 позиций. Кинотеатр Okko переместился со 124-й на 31-ю позицию.

Такой стремительный рост связан не только с общим повышением спроса на развлекательный контент в интернете, но и с эффективной трансформацией предложения со стороны мультимедийных онлайн-платформ и сервисов - большинство из них предложили клиентам выгодные условия подписки, а также уделяли внимание предоставлению качественного контента.

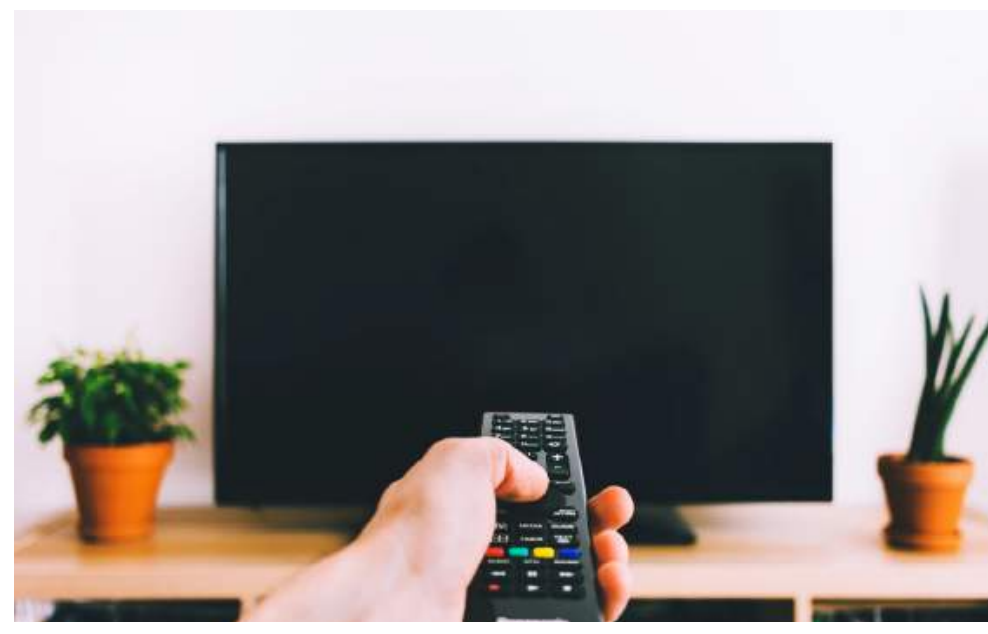

По мнению аналитиков из PwC, после окончания самоизоляции трафик онлайн-видеосервисов снизится, поэтому чтобы удержать новых клиентов, платформам необходимо будет активно внедрять новый контент, например, спортивный, которого так не хватало зрителям во время самоизоляции. Также ожидается, что в тренде будет качественный do it yourself КОНтент ${ }^{44}$.

$\begin{array}{ll}\text { Гипотеза } & \begin{array}{l}\text { Краткосрочный прогноз } \\ \text { (1-3 года) }\end{array} \quad \text { Среднесрочный прогноз (5-7 лет) }\end{array}$

\section{Произошло}

перенасыщение

отдельными видами медиа и контентом
После выхода из самоизоляции пользователи вернутся в привычный режим пользования развлекательными онлайнплатформами. Однако у развлекательных сетевых сервисов есть возможность сохранить новую аудиторию с помощью выгодных предложений подписок, качественного контента и т. д.
Удержание новой большой аудитории возможно благодаря соблюдению ключевых условий, которыми сейчас характеризуется запрос от пользователей: система умного поиска и удобные фильтры, безупречная техническая работа сервиса, баланс простоты и контроля управления, внедрение интерактивных функций, качественная система подбора рекомендаций, удобство использования сервиса на любом устройстве. Российский рынок развлекательных онлайн-платформ (в первую очередь, кинотеатры) будет продолжать стремительно расти за счет:

- увеличения у пользователей количества устройств для просмотра видео;

- снижения стоимости телевизоров с функцией SmartTV;

- активного блокирования пиратских ресурсов;

- отказа от аналогового вещания в РФ;

- развития платежных систем. 
По результатам исследования ФОМ, на самоизоляции 27\% россиян стали проводить в интернете больше времени, чем раньше. Если соотнести это с нынешней общей активностью медиапотребления, то можно предположить, что нахождение на самоизоляции отразилось на степени удовлетворения потребности человека в развлечениях и произошло перенасыщение отдельными видами медиа и контентом.
В исследовании Аналитического центра НАФИ приводятся данные о том, что половина россиян испытывала чувство пресыщения информацией во время самоизоляции (46\%). А треть опрошенных успели посмотреть за это время практически все, что могло их заинтересовать в плане кино или сериалов (35\%).

\section{«С какими утверждениями в отношении}

\section{пользования интернетом вы согласны?»}

в \% от всех опрошенных

В последнее время я так много времени провожу в интернете, что чувствую перенасыщение информацией

В последнее время мне сложно найти интересное кино, сериал, так как я уже посмотрел(-а) практически все, что могло меня заинтересовать

Периодически я устраиваю информационные «детокс-дни», когда полностью или частично отказываюсь от интернета
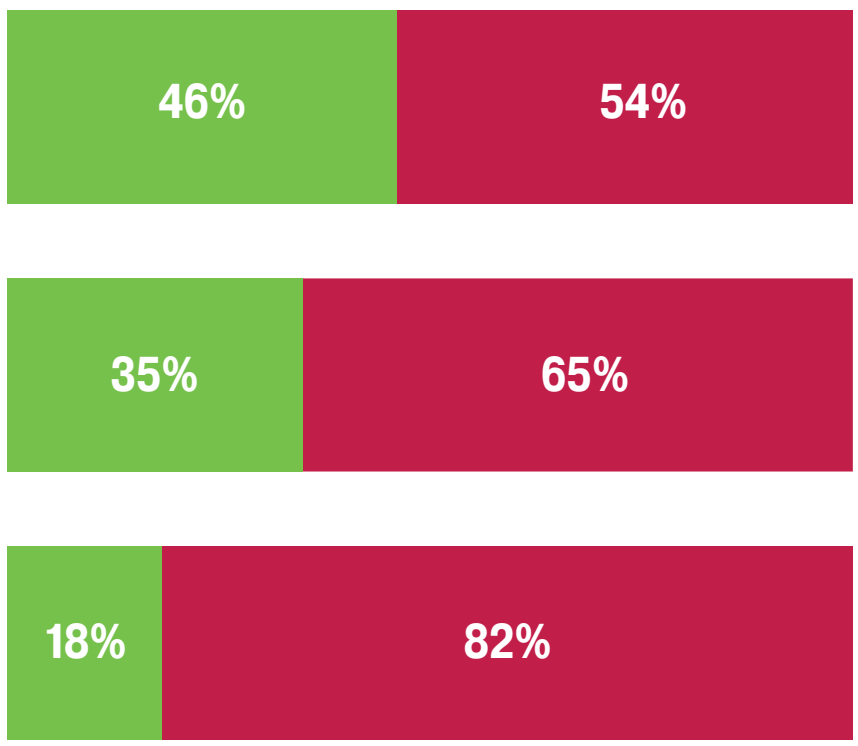

Да
Нет
Проведенное Аналитическим центром НАФИ качественное исследование демонстрирует еще один факт, связанный с активным медиапотреблениеммногие опрошенные отметили смещение режима сна (на 2-3 часа). Это вызвано тем, что люди стали позволять себе допоздна засиживаться за компьютером, просмотром кино, сериалов, компьютерными играми, так как в нынешних условиях строгий рабочий график у многих отсутствует.

«Так как мы можем спать утром подольше, мы с мужем ночью смотрели фильмы» [руководитель компании, женщина, 34 года, Уфа]
«Заметил сильное изменение режима сна, даже учитывая тот факт, что до этого также работал из дома. Режим изменился и у ребенка. В среднем на 2-3 часа» [консультант-аналитик, мужчина, 41 год, Вашингтон]

После отмены самоизоляции и возвращения россиян к обычному режиму жизни будет наблюдаться спад активности потребления медиаконтента в силу того, что значительная часть населения вернется на работу и не будет иметь столько времени, сколько его было во время карантина. Однако выгодные условия подписок на платные сервисы, предоставляющие качественный контент, могут помочь сохранить клиентов. 


\section{СВОБОДНОЕ ВРЕМЯ И ПРОГУЛКИ}

$\begin{array}{lll}\text { Гипотеза } & \text { Краткосрочный прогноз (1-3 года) } & \text { Среднесрочный прогноз (5-7 лет) } \\ \text { Лето-2020: досуг на открытом } & \text { Вырастет популярность развлечений } & \text { В среднесрочной перспективе } \\ \text { воздухе станет крайне востребован } & \text { в парках, пикников, отдыха } & \text { ситуация вернется в норму } \\ & \text { на отрытом воздухе. Как следствие, } & \text { и проведение досуга будет } \\ & \text { возрастет спрос на дачные } & \text { определяться различными } \\ & \text { принадлежности, спортинвентарь для } & \text { факторами-погодой, настроением, } \\ & \text { активного отдыха, средства защиты } & \text { привычками и проч. } \\ & \text { от солнца и т. д. } & \end{array}$

Факт наличия чувства перенасыщения медиаконтентом и долгое отсутствие возможности досуга на открытом воздухе приводит к повышению ценности активности на свежем воздухе и росту развлечений в офлайне - отдыху на улице, пикникам, прогулкам.

Результаты исследования, проведенного Аналитическим центром НАФИ, подтверждают эту гипотезу. Подавляющее большинство россиян будут стараться проводить на открытом воздухе как можно больше времени (87\%). В то же время обозначилась тенденция к продолжению соблюдения базовых принципов безопасности - избеганию общественных мест в закрытых помещениях без крайней необходимости, мест скопления людей и соблюдению дистанции (63\%).

\section{«Ниже приведены высказывания других людей}

\section{о планах на период после отмены самоизоляции.}

\section{Насколько вы согласны с каждым из них?»}

в \% от всех опрошенных

я буду стараться проводить как можно больше времени на открытом воздухе

Я буду стараться не посещать общественные места в закрытых помещениях без крайней необходимости я буду продолжать избегать мест скопления людей,
соблюдать дистанцию и меры предосторожности

Не согласен

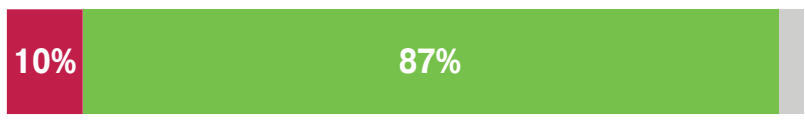

$3 \%$

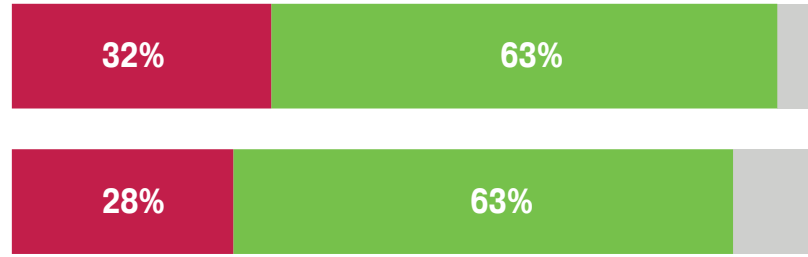

$5 \%$ $9 \%$

Источник: опрос населения, n=500, НАФИ, июнь 2020 года

Безусловно, намерение россиян проводить больше времени на улице с друзьями, семьей открывает дополнительные возможности для роста продаж принадлежностей для пикников и шашлыков, дачного инвентаря, игр на открытом воздухе, средств защиты от солнца и т. д. 


\section{ДОВЕРИЕ К СМИ И МЕДИАПОТРЕБЛЕНИЕ}

$\begin{array}{lll}\text { Гипотеза } & \text { Краткосрочный прогноз (1-3 года) } & \text { Среднесрочный прогноз (5-7 лет) } \\ \text { Уровень медиапотребления } & \text { Уровень медиапотребления взлетел } & \text { Выделится и будет расти группа людей, } \\ \text { значительно вырос } & \text { в первые недели самоизоляции, } & \text { получающих основную информацию, в т. ч. } \\ & \text { однако к концу третьего месяца } & \text { новости, не по традиционным каналам } \\ \text { пребывания дома этот уровень } & \text { (телевидение, газеты, радио), а через } \\ \text { начал выравниваться, возвращаясь } & \text { социальные сети, подкасты и проч. } \\ & \text { к обычному } & \text { Это приведет кдальнейшему развитию } \\ & \text { «народных медиа», когда любой человек }\end{array}$

В период пандемии уровень медиапотребления россиян существенно вырос, что обусловлено желанием населения получать максимально полную информацию о происходящих событиях в условиях крайней неопределенности.

Телесмотрение выросло в сравнении с аналогичным периодом прошлого года. Это подтверждают данные Mediascope, согласно которым данный тренд можно отследить по периоду майских праздников (за неделю 4.05-10.05 телесмотрение выросло на 12\% по сравнению с аналогичным периодом прошлого года), так и по периоду после праздников (на неделе с 11.05 по 17.05 - плюс 16\% в сравнении с той же неделей 2019 года). Однако время просмотра ТВ падает по сравнению с начальными неделями карантина, например, по сравнению с первой неделей-на 18\% во всех возрастных группах ${ }^{45}$.

В нынешних условиях СМИ получили крупный приток новой, но еще не лояльной к ним аудитории. Период выхода из самоизоляции станет вызовом для медиа в вопросах сохранения новых потребителей.

В этом контексте важен вопрос доверия к источникам информации. Компания Online Market Intelligence и Центр социального проектирования «Платформа» провели соответствующее исследование. Результаты показали, что в период пандемии
54\% опрошенных россиян стали меньше доверять средствам массовой информации ${ }^{46}$.

«Люди больше склонны прислушиваться к мнению друзей, коллег, а не родственников (родителей, детей). Очень высокий уровень недоверия к информации, даже самой очевидной. Люди не верят в вирус. Официальным источникам верят меньше, чем людям в соцсетях» [консультант-аналитик, мужчина, 41 год, Вашингтон]

Таким образом, период пандемии характеризовался противоречивостью, когда население намного чаще, чем обычно обращалось к СМИ за актуальной информацией по теме коронавируса, официальным сводкам заболевших, вводимым мерам безопасности, но при этом декларировало низкий уровень доверия этим данным. В целом это характерная ситуация для любого кризисного периода. Однако даже после завершения эпидемии значительный уровень недоверия и тревожности сохранится среди всех аудиторий СМИ. пандемии COVID-19»/ Доступно по ссылке: https://www. sostav.ru/publication/brandscience-privychki-rossiyan-vo-vremyapandemii-covid-19-43515.html

\author{
«Исследование социальных эффектов пандемии \\ COVID-19» / Доступно по ссылке: http://sociocrisis.ru/files/ \\ sac report 13.pdf
}




\section{ПУТЕШЕСТВИЯ И ТУРИЗМ}

\begin{tabular}{|c|c|c|}
\hline Гипотеза & Краткосрочный прогноз (1-3 года) & Среднесрочный прогноз (5-7 лет) \\
\hline $\begin{array}{l}\text { Из-за самоизоляции } \\
\text { обострится желание } \\
\text { к путешествиям, но бюджет } \\
\text { поездок будет небольшим } \\
\text { из-за падения доходов }\end{array}$ & $\begin{array}{l}\text { В период после отмены режима } \\
\text { самоизоляции будут популярны } \\
\text { внутрироссийские направления, } \\
\text { либо путешествия в страны ближнего } \\
\text { зарубежья в силу сохранения } \\
\text { ограничений на пересечение границ } \\
\text { ряда стран, снижения доходов } \\
\text { и общей посткризисной осторожности } \\
\text { в отношении массовых скоплений } \\
\text { людей в закрытых пространствах } \\
\text { (транспорт, гостиницы ит. д.) }\end{array}$ & $\begin{array}{l}\text { Уровень авиаперевозок будет восстановлен. } \\
\text { Внутренние российские направления могут } \\
\text { стать популярными и востребованными } \\
\text { среди населения, если в посткризисный } \\
\text { период у представителей российской } \\
\text { туристической отрасли получится создать } \\
\text { лояльную аудиторию среди туристов, } \\
\text { впервые посетивших российские курорты } \\
\text { в отпускной сезон после окончания } \\
\text { эпидемии }\end{array}$ \\
\hline
\end{tabular}

Ограничение на свободное передвижение стало одним из главных вызовов для людей, оказавшихся в условиях самоизоляции. Закрытие границ регионов и стран стало причиной отмены запланированных командировок, посещения родственников, учебы и отпусков. В начале отпускного сезона туризм стал одной из отраслей, понесших самые крупные убытки

Аналитический центр НАФИ провел исследование планов россиян в отношении путешествий в отпуске в этом году. Результаты показали, что, несмотря на сложную эпидемическую и экономическую ситуацию, 67\% российских туристов (9\% от всех россиян) планируют поехать в отпуск нынешним летом.
Российские туристы проявляют сдержанный оптимизм в оценке перспектив отправиться за рубеж в ближайшее время -треть (33\%) из них ожидает открытия границ в июне-июле 2020 года, а 64\% в течение ближайших шести месяцев.

По оценкам россиян, отказ от путешествия этим летом вызван не опасениями за здоровье (13\%), а отсутствием технических возможностей (закрытые границы, приостановка работы гостиниц и т. д.) 56\%, снижением текущих доходов - 18\%.

Большинство российских туристов (88\%) после нормализации эпидемической ситуации предпочтут отдых за границей. 44\% туристов в ближайшей перспективе поехали бы отдыхать в страны Европы, 23\% - в Азию. Только 12\% выбрали бы путешествие по России.

\section{«Представим, что эпидемиологическая ситуация в мире}

\section{стабилизировалась, и вы планируете свой отпуск. Куда вы отправитесь в путешествие с наибольшей вероятностью?»}

в \% от всех опрошенных россиян, совершавших туристические поездки за последние 2 года

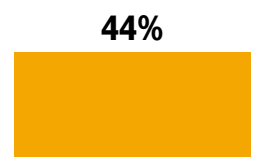

В Европу

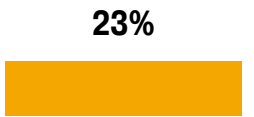

В Азию
$4 \%$

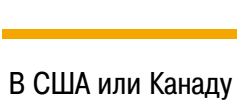

$3 \%$

В страны СНГ
$14 \%$

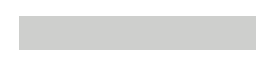

Другое 


\section{ИндУСтРИЯ МОДЫ}

\begin{tabular}{|c|c|c|}
\hline Гипотеза & Краткосрочный прогноз (1-3 года) & Среднесрочный прогноз (5-7 лет) \\
\hline $\begin{array}{l}\text { Модная индустрия успешно } \\
\text { адаптировалась к онлайн-формату }\end{array}$ & $\begin{array}{l}\text { B fashion-категории может быть } \\
\text { ощутимый рост продаж после } \\
\text { завершения эпидемии и возвращения } \\
\text { офлайн-магазинов к работе. Однако } \\
\text { он не выйдет на докризисный } \\
\text { уровень в ближайший год. } \\
\text { По оценкам экспертов, до 50\% } \\
\text { российских компаний, занятых } \\
\text { в модной индустрии, может } \\
\text { ожидать банкротство. Потребители } \\
\text { будут делать выбор в пользу } \\
\text { качества, практичности, комфорта, } \\
\text { экологичности, минимализма } \\
\text { и простоты. Возврат к локальным, } \\
\text { местным производствам }\end{array}$ & $\begin{array}{l}\text { E-commerce станет неотьемлемой } \\
\text { составляющей отрасли. Ожидается } \\
\text { переход к устойчивому потреблению } \\
\text { и отказ от «быстрой моды» - } \\
\text { потребители станут рассматривать } \\
\text { покупку одежды, скорее, как } \\
\text { инвестиции, а не как погоню } \\
\text { за модными трендами. Они будут } \\
\text { приобретать вещи, которые } \\
\text { прослужат долго и не будут за один } \\
\text { сезон терять ярлык «модно» }\end{array}$ \\
\hline
\end{tabular}

По оценкам экспертов, индустрия моды занимает второе место по размерам убытков в результате распространения эпидемии коронавируса. Однако пандемия также задает специфические тренды в модной индустрии и формирует новые подходы к потреблению данной категории товаров. Бренды создают новые коммуникационные стратегии, инвестируют в развитие продаж через интернет и даже переносят традиционные недели моды в онлайн.

Массовый переход на удаленную работу также наложил отпечаток на уровень потребления модной продукции. Постоянное нахождение дома, запрет на массовые мероприятия, отмена планов на летний отпуск лишили потребителей стимула обновлять гардероб. Именно этот факт сказался в наибольшей мере на массовых и люксовых сегментах модной индустрии.

Фактор сезонности спроса сыграл значимую роль в создании больших объемов нераспроданного товара, когда весной закрылись все магазины модной одежды. Учитывая снижение доходов населения и меры предосторожности в плане посещения торговых центров, выручка магазинов модной одежды после выхода из эпидемии вряд ли достигнет показателей за аналогичный сезон прошлых лет. Это подтверждают эксперты GfK на основании результатов проведенного ими исследования «Эффект COVID-19»- ожидается ощутимый рост продаж после завершения эпидемии и возвращения офлайнмагазинов к работе в fashion-категории. Однако он не выйдет на докризисный уровень ${ }^{47}$.
Текущая ситуация может повлечь за собой окончание эпохи быстрой моды, когда и бренды, и клиенты будут делать ставку на устойчивое потребление - вещи будут отвечать базовым потребностям, служить дольше и стоить дороже. Еще до начала эпидемии наблюдалось смещение потребительских предпочтений в сторону более осознанного шопинга, особенно среди молодых потребителей. И пандемия усилила эту тенденцию. Эксперты консалтинговой компании McKinsey отмечают: «Бренды, которые изменят свои миссии и бизнес-модели в соответствии с устойчивым развитием, смогут обслуживать более привлекательную аудиторию, чем когда-либо прежде» ${ }^{48}$. В связи с этим можно также ожидать роста локализации производств.

Но главное в нынешнем модном сезоне - максимально точно соответствовать спросу потребителя. Решением может стать снижение числа позиций В коллекциях, что предположительно будет способствовать их более скорой распродаже. Одним из важных ожидаемых изменений в мире моды можно назвать пересмотр понятия сезонности в цепочке и приближение ее к реальной смене времен года. Предполагается, что актуальный в последнее время тренд на экологичность товаров может заметно снизиться, уступив место предложению базовых продуктов, основанному на реальных нуждах рынка.

Эксперты McKinsey также прогнозируют бум скидок и спецпредложений, которые будут предлагать ритейлеры после выхода из эпидемии. Однако это может спровоцировать банкротство небольших, 


\section{ОТНОШЕНИЕ К ГОСУДАРСТВУ И ГОСУДАРСТВЕННЫМ УСЛУГАМ}

Количество интернет-пользователей в России составляет 118 миллионов человек, или 81\% россиян. Пандемия и самоизоляция заставили граждан резко погрузиться в цифровую среду. Но не только граждане сделали цифровой скачок, но и государство. Так, Минкомсвязи России и АНО «Цифровая экономика» при поддержке крупнейших российских интернет-компаний запустили портал все.онлайн (vseonline.online), на котором была собрана информация о цифровых сервисах и услугах для граждан, находящихся в режиме изоляции в связи с распространением коронавируса.

Таким образом, пандемия стала драйвером для цифровизации, а цифровизация - одним из немногих средств не допустить полной остановки экономики, да и жизни в целом. Сохранится ли этот импульс после отмены карантина или с возвращением людей в офлайн необходимость в части цифровых услуг исчезнет?

\begin{tabular}{|c|c|c|}
\hline Гипотеза & Краткосрочный прогноз (1-3 года) & Среднесрочный прогноз (5-7 лет) \\
\hline Проблемы с цифровыми пропусками & Развитие цифровых услуг приведет & Рост пользования электронными \\
\hline и зависанием портала gosuslugi.ru & к еще большему контролю & госуслугами замедлится, возрастет \\
\hline навредили имиджу государства как & со стороны государства, если & нагрузка на телефонные линии \\
\hline оператору цифровых услуг: люди & не будет пропагандироваться & и МФЦ. Возможное решение \\
\hline станут меньше доверять цифровым & и реализовываться иное & со стороны государства: \\
\hline сервисам и защите персональных & & безальтернативное предоставление \\
\hline данных со стороны государства, & & ряда услуг в электронном виде \\
\hline \multicolumn{3}{|l|}{ государство будет восприниматься } \\
\hline \multicolumn{3}{|l|}{ как субъект, повсеместно } \\
\hline осуществляющий цифровой контроль & & \\
\hline
\end{tabular}

В условиях активного перехода в онлайн вопросы распоряжения персональными данными человека, его контроль над их использованием и распространением и то, что часто называют «цифровым следом» человека, становятся более острыми. Пандемия вынудила граждан передавать государству чрезвычайный объем данных об их частной жизни. В первую очередь, через портал gosuslugi.ru, которым воспользовались 51\% опрошенных россиян во время пандемии, еще 28\% пользовались ранее.

\section{«Пользовались ли вы}

\section{на самоизоляции порталом}

$$
\text { "Госуслуги", например, для }
$$$$
\text { оформления пропусков, для }
$$

подачи заявлений на выплаты и с другими целями?»

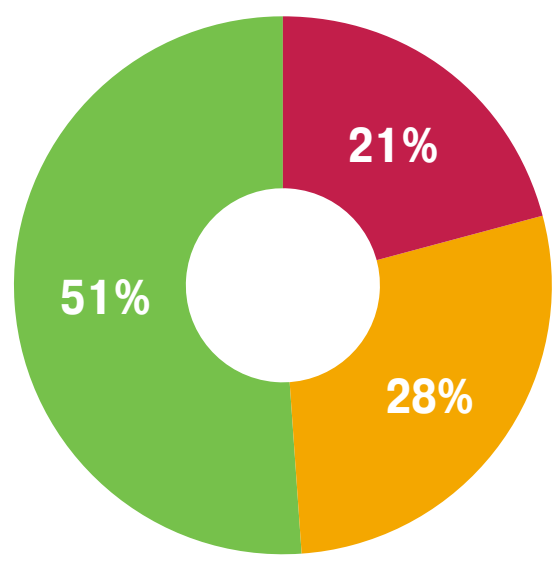

Да, пользовались

Нет, не пользовались во время самоизоляции, но пользовались когда-либо ранее

Никогда не пользовались 
82\% граждан, из тех, кто пользуется порталом, считают, что электронные государственные сервисы упрощают взаимодействие с государственными органами. При этом 70\% не уверены в безопасности своих персональных данных, которые они оставили на государственных сервисах. Периодически возникают ситуации с «утечкой данных», причем со стороны сотовых операторов, банков и других компаний, которые подрывают надежность как отдельных компаний, так и цифровизации в целом.

\section{«Уверены ли вы в безопасности персональных данных, которые вы оставили о себе на сайтах государственных сервисов (Госуслуги, mos.ru, ФНС и др.), или не уверены?»}

в \% от всех опрошенных, использовавших соответствующие интернет-порталы

\section{Скорее уверены}

Скорее не уверены

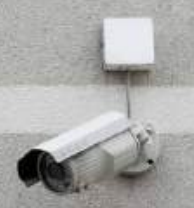

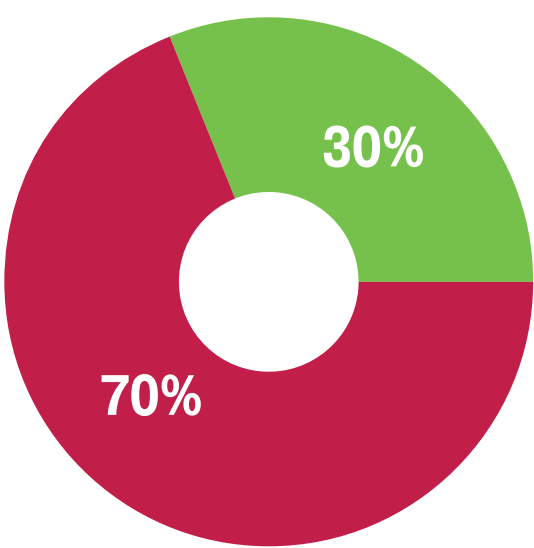

Источник: всероссийский опрос населения, n=1600, НАФИ, май 2020 года

Коронавирус стал для некоторых государств удобным предлогом для ужесточения контроля за гражданами, однако, не во всех странах. Так, в странах Европы к персональным данным и частной жизни относятся иначе, чем, например, в Китае, где уже стало реальностью появление социального паспорта и социального рейтинга, согласно которому государство осуществляет контроль над поведением граждан.

«В Женеве люди старались соблюдать локдаун, но это был мягкий локдаун. Именно поэтому государство не приводит статистику по немногочисленным выписанным штрафам. Здесь государство ценит человеческую свободу и обладает хорошей медициной» [специалист в сфере digital-pr, женщина, 33 года, Женева]

В то же время, активный анализ государством больших данных (например, отслеживание сигналов мобильных телефонов и пр.) позволял властям ряда 
стран (Сингапур, Южная Корея, Германия) быстро находить и изолировать тех, кто общался с заразившимся коронавирусной инфекцией.

Что касается россиян, они считают, что развитие цифровых технологий - это, скорее, благо для государства, чем вред (согласны 63\%), и также благо для отдельного человека (почти столько же - 62\% согласных). Однако при этом более половины опро- шенных уверены, что государство развивает цифровые сервисы, чтобы следить за своими гражданами (55\%), а 49\% кажется, что их цифровые устройства уже сейчас следят за ними.

\section{«Согласие с высказываниями в отношении}

\section{безопасности в интернете»}

в \% от всех опрошенных

В целом я чувствую себя защищенно, когда нахожусь онлайн

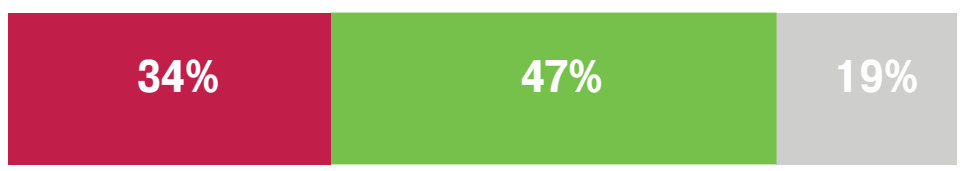

Мне иногда кажется, что мои цифровые и мобильные устройства следят за мной слышат, о чем я говорю, видят, что я делаю

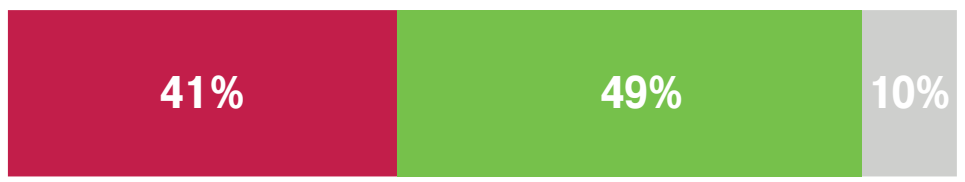

Развитие цифровых технологий - это, скорее, благо для государства, чем вред

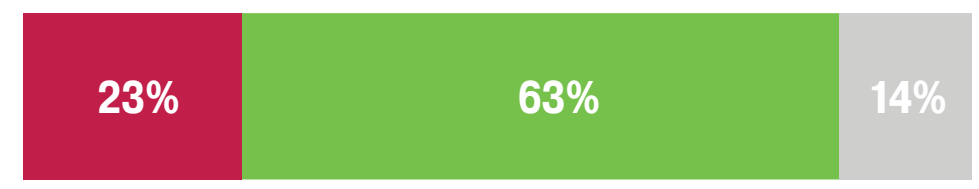

Случившаяся пандемия и ограничения, с ней связанные, положительно влияют на развитие цифровых технологий в стране

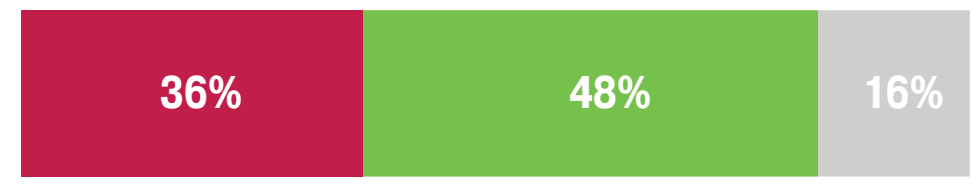

Информация, которую я оставляю о себе на различных сайтах, включая данные моей банковской карты, не может попасть в руки мошенников

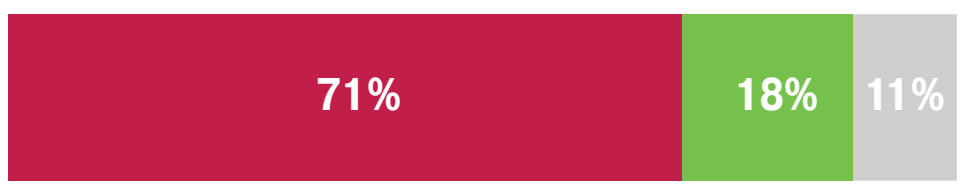

Государство развивает цифровые технологии для того, чтобы следить за своими гражданами

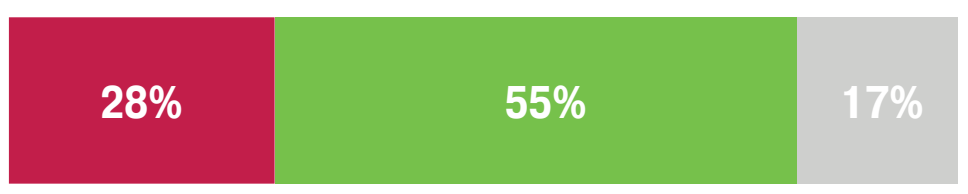

Не согласны

Согласны

Затрудняюсь ответить 
Роль государства состоит в том, чтобы сформировать у граждан мотивацию к движению к цифровому обществу, мобилизовать граждан двигаться в этом направлении, и пандемия оказала в этом смысле большую услугу. В настоящее время для продолжения начатого прогрессивного движения необходимо усилить доверие граждан к цифровым сервисам, показать, что они, в первую очередь, развиваются ради удобства граждан страны, ради ликвидации бюрократических процедур, а не ради осуществления контроля над гражданами со стороны государства.
В то время как цифровое государство воспринимается настороженно, цифровое общество является синонимом развития и процветания. Если не вести планомерную работу в этом направлении, рост недоверия граждан к цифровым сервисам будет нарастать, что приведет в долгосрочной перспективе к «откату»: к преимущественному использованию традиционных каналов взаимодействия с государством - телефонным звонкам, очным визитам в различные учреждения и ведомства.

\section{ДЕМОКРАТИЗАЦИЯ И РАЗВИТИЕ ГРАЖДАНСКОГО ОБЩЕСТВА}

$\begin{array}{lll}\text { Гипотеза } & \text { Краткосрочный прогноз (1-3 года) } & \text { Среднесрочный прогноз (5-7 лет) } \\ \text { Ввиду недостаточной поддержки } & \text { Повышение значимости } & \text { Появяся новые политические партии } \\ \text { людей со стороны государства } & \text { профессиональных союзов } & \text { и движения, усилится оппозиция } \\ \text { возрастет количество нелояльных } & \text { и ассоциаций. } \\ \text { граждан, меньше станет тех, кому } & \text { Активное участие государства в } & \text { развитии системы здравоохранения и } \\ \text { «все равно» } & \text { демонстрация этого участия. } & \text { В случае нежелания властей } \\ & \text { повышать эффективность своей } \\ & \text { работы в социально-экономической } \\ & \text { сфере доверие к власти будет падать }\end{array}$

Пандемия привела к тому, что часть граждан потеряли работу, у них сократились доходы. В ответ на это правительство ввело различные меры поддержки, в основном для малообеспеченных граждан:

• увеличены пособия по безработице;

- $\quad$ введены единовременные выплаты на детей от 3 до 16 лет;

- введены кредитные каникулы и каникулы по ипотеке;

- $\quad$ введены меры по поддержке соцработников и медицинского персонала;
- упрощены методики подачи документов на инвалидность, на постановку на учет по безработице и другие.

Оценки населением действий государства разделились. Так, 37\% отмечают, что государство делает много, в то время как 60\% отметили, что государство делает мало и этого недостаточно. 
«В России государство

делает все от него зависящее

для поддержки простых

граждан или уделяет

поддержке простых граждан

недостаточное внимание?»

в \% от всех опрошенных

Источник: всероссийский опрос населения, $\mathrm{n}=1600$, НАФИ, май 2020 года

Пандемия выявила такой интересный феномен как ковид-диссидентство, при котором человек считает, что ситуация с пандемией надуманная и избыточно раздувается СМИ. Здесь встает вопрос о доверии таких людей средствам массовой информации. Можно утверждать, что ковид-диссиденты относятся к тем, на кого не удастся воздействовать по традиционным каналам СМИ. Доля таких диссидентов по разным оценкам достигала 25\%, причем представители этой группы-в основном молодые люди.

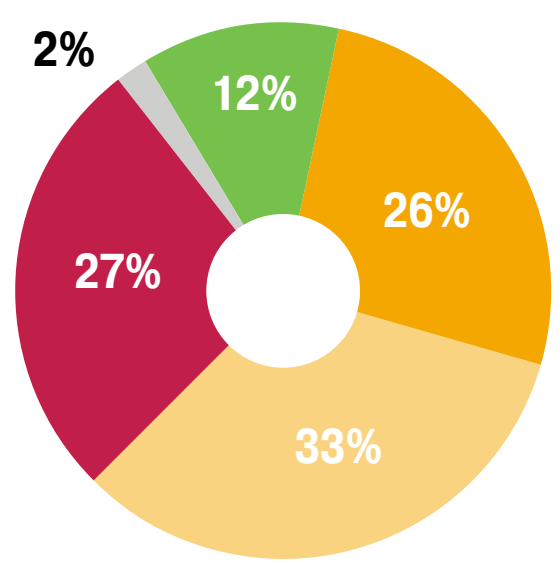

Делает все возможное, чтобы поддержать граждан

Делает многое, но этого недостаточно

Делает мало, этого явно недостаточно

Не делает ничего или практически ничего

Затрудняюсь ответить

В связи с этим стоит отметить проблему половинчатых решений, которая характеризует принятые меры. Жесткость принятых мер компенсировались необязательностью их исполнения, что не вызывает критики и отторжения со стороны населения (мы делаем вид, что соблюдаем, вы делаете вид, что не замечаете). В то время как со стороны граждан наблюдался запрос на более жесткие, строгие ограничения и на их неукоснительное исполнение.

\section{«Как вы оцениваете меры, введенные в России?»}

в \% от всех опрошенных

Нужно было вводить более жесткие меры

Введенные меры были правильные, но нужно было строже следить за их исполнением

Меры были правильные

Можно было бы обойтись и более мягкими мерами

Затрудняюсь ответить

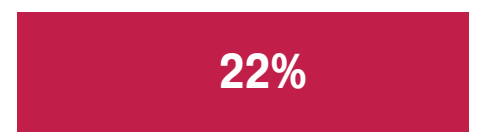

\section{$31 \%$}

\section{$16 \%$}

\section{$19 \%$}


Более половины опрошенных оценили меры как правильные. При этом 34\% считают, что нужно было строго следить за исполнением мер. За более жесткие ограничительные меры высказался каждый пятый опрошенный.

Таким образом, проявившаяся проблема половинчатых решений приводит, во-первых, к низкой эффективности принимаемых решений, а во-вторых, снижает общий уровень доверия власти.

В условиях глобального кризиса в области здравоохранения, в условиях COVID-19 системы здравоохранения многих стран подверглись серьезным испытаниям. В целом, системы здравоохранения испытывают различные уровни напряженности на фоне роста заболеваемости. Тем не менее, решения правительства были направлены на поддержку здравоохранения в ближайшие месяцы. На борьбу с коронавирусом (без учета помощи бизнесу) власти уже потратили более 160 млрд рублей. Около 78 млрд рублей получили регионы на создание мест в больницах для лечения больных вирусом, еще около 20 млрд рублей власти направили на закупку медицинского оборудования и машин скорой помощи. А 50 млрд рублей-на оплату работы врачей, в том числе на надбавки тем, кто лечит больных вирусом ${ }^{49}$

Изменения коснулись не только самой системы здравоохранения, но и отношения к врачам в российском обществе, внимания к их проблемам и к ситуации в целом. В России первый диагноз «коронавирусная инфекция» был поставлен пациенту 1 марта. Согласно рейтингу Bloomberg, в десятку стран с самым эффективным здравоохранением входят: Гонконг (88,9 балла), Сингапур $(84,2)$, Испания $(72,2)$, Южная Корея $(71,5)$, Япония $(68,2)$, Италия $(67,7)$, Израиль $(66,8)$, Чили $(65,2)$, Объединенные Арабские Эмираты $(64,3)$ и Австралия $(62,0)$. США $(32,2)$ находятся на 50-м месте - главным образом за счет колоссальных расходов на здравоохранение: 17\% ВВП. Россия $(24,3)$ занимает в этом рейтинге 95-е место. Можно заметить, что в этом рейтинге Италия, Испания и США стоят гораздо выше России, в то время как весь мир стал свидетелем катастрофы, развернувшейся в этих странах.

Можно сказать, что российская система здравоохранения приобрела «человеческое лицо» - сначала в лице главного врача больницы в Коммунарке Дениса Проценко, а затем через многочисленные рассказы медиков в социальных сетях и СМИ о том, с какими трудностями они сталкиваются. Эти рассказы мало кого оставили равнодушными. В Москве и других городах также можно встретить билборды с фотографиями медицинских работников и со словами благодарности к ним.

Помимо очеловечивания этой сферы, в здравоохранении произошли следующие изменения. Произошел резкий скачок в развитии дистанционных медицинских сервисов, причем как государственных ${ }^{50}$, так и частных ${ }^{51}$. Если раньше консультирование пациентов онлайн не поощрялось, и консультация часто сводилась к совету посетить врача, то сейчас таким способом вполне реально получить схему лечения и список необходимых препаратов. Выросло и количество запросов по теме - на текущий момент в Google количество запросов по теме «врач онлайн» составило 74 млн, а о возможностях получить консультацию врача онлайн информированы 62\% россиян ${ }^{52}$.

Предполагаем, что и после пандемии эти сервисы не утратят актуальность, а лишь будут развиваться в направлении внедрения инноваций и технологизации (через датчики слежения за температурой, давлением, походкой, составом крови и проч.). Как сопутствующий эффект вырос рынок добровольного медицинского страхования, причем именно посредством онлайн.

Таким образом, статус, общественная и экономическая роль здравоохранения возрастут, что приведет к экономическим вложениям в эту сферу.

Новости портала mos.ru / Доступно по ссылке: https://www. mos.ru/news/item/73425073/

«Медси» создала цифровую платформу для мониторинга здоровья». Ведомости / Доступно по ссылке: https://www. vedomosti.ru/technology/articles/2020/02/27/823968-medsisozdala-tsifrovuyu-platformu по ссылке: https://infographics.wciom.ru/theme-archive/ society/social-problems/most-serious-problems/article/ telemedicina-v-rossii-segodnja-i-zavtra.html 


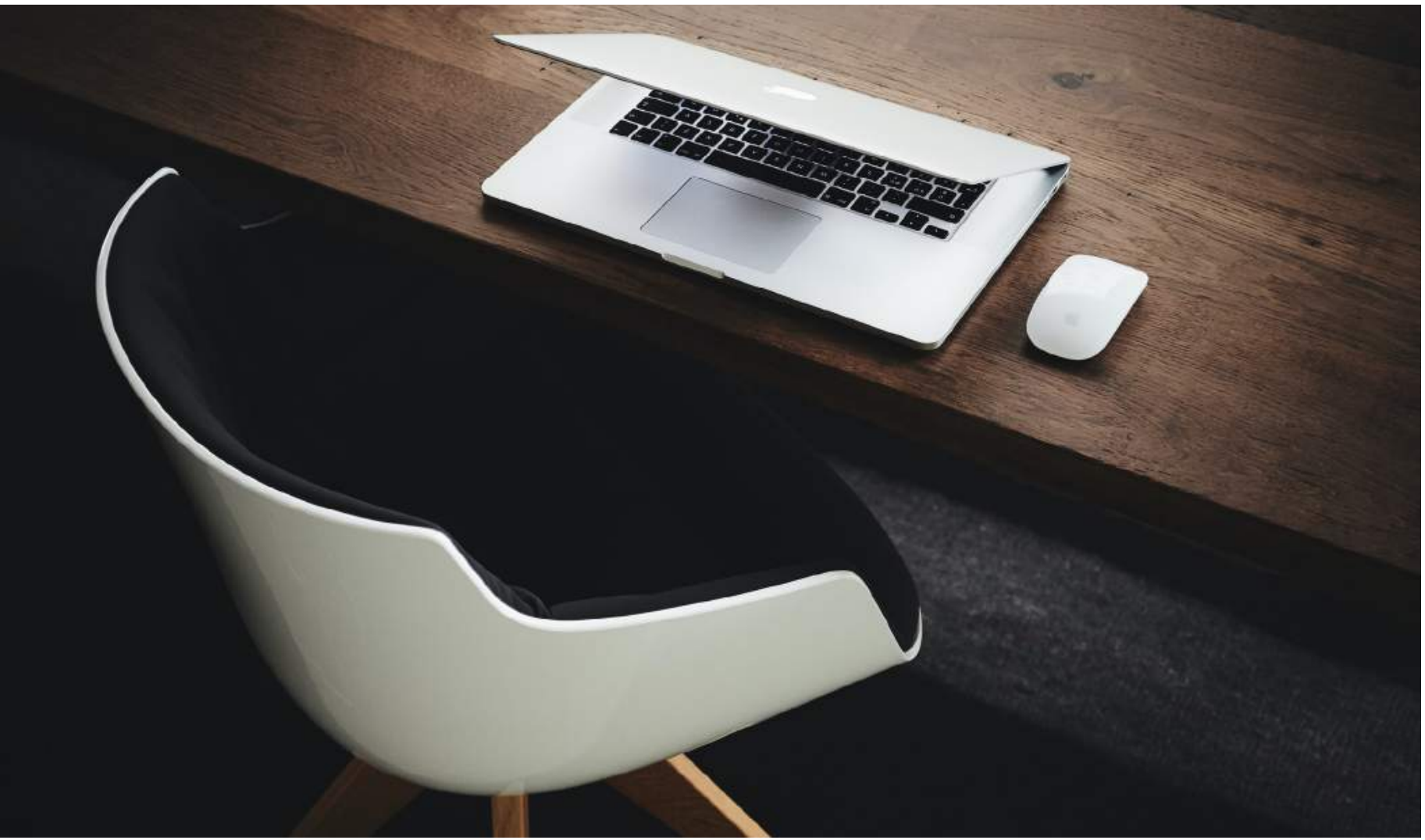

Большинство россиян отвечают, что будут вспоминать самоизоляцию как время, проведенное с пользой. Как показали многочисленные исследования, проведенные нами и другими исследовательскими компаниями во всем мире,--высвободившееся время россияне потратили на то, чему по-настоящему придают первостепенное значение - семье, бизнесу, образованию, спорту, досугу или чему-то еще для них важному.

«После отмены карантина, когда все в жизни и работе вернется на свои места, вы будете вспоминать время, проведенное дома, как время, проведенное с пользой, или как время упущенных возможностей?»

в \% от всех опрошенных

Источник: всероссийский опрос населения, $\mathrm{n}=1600$, НАФИ, май 2020 года

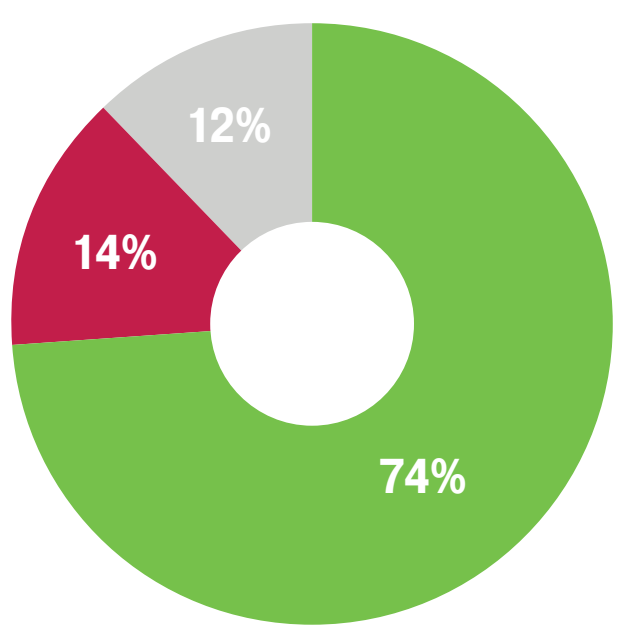

Скорее первое - как время, проведенное с пользой

Скорее второе - как время упущенных возможностей Затрудняюсь ответить 
Разумеется, были и сожаления о возможностях, упущенных если не во время пандемии, то до нее. О возможностях, которые можно было реализовать раньше и, тем самым, лучше подготовиться к коронакризису и времени, которое наступит после него.

\section{В ходе интервью мы задали людям вопрос: если бы они могли отправиться в прошлое, например, за год до эпидемии коронавируса - какое сообщение} они бы себе передали, что бы себе посоветовали, о чем бы предупредили? Проанализировав ответы, мы сделали несколько интересных выводов:

1. В обществе растет запрос на социальный капитал и крепкие горизонтальные связи. В основном это происходит из-за дефицита поддержки государства и ослабления уверенности в себе в кризисные периоды.

«Я бы посоветовала себе больше общаться с людьми и слушать всех, кто вокруг меня находится. Было бы больше тех, от кого можно в трудную минуту получить поддержку» [руководитель компании, женщина, 34 года, Уфа]

\section{2. У людей с высокой чувствительностью и го-} товностью к изменениям (чаще всего это молодежь, предприниматели, люди творческих профессий) наблюдается синдром опоздания, осознание того, что они не успевают за временем. Вероятно, за такими людьми - инновации и прогресс. И их неугасаемое стремление к развитию требует всесторонней поддержки как со стороны общества, так и со стороны государства.

«Я бы посоветовала себе более активно заниматься предпринимательством и развивать собственные идеи, чтобы успеть в новом времени запустить новый бизнес. Сейчас есть ощущение, что за временем не успеваешь» [специалист в сфере digitalpr, женщина, 33 года, Женева]

«Я бы себя подгонял, чтобы успеть сделать какие-то большие проекты, которые сейчас уже будет сложнее реализовать» [консультант-аналитик, мужчина, 41 год, Вашингтон]
3. Остается в то же время и значительная по численности категория людей с традиционными взглядами и пассивной, наблюдательной позицией - тех, кто привык жить настоящим, верит в судьбу и не готов планировать будущее, учитывая ошибки прошлого.

«Не хочу фантазировать, живу здесь и сейчас. Не хочу думать о том, что будет завтра. Хотя, конечно, думаю и анализирую. Но чем больше думаешь, тем больше седых волос на голове» [руководитель строительной компании, мужчина, 55 лет, Москва]

4. Компенсаторным эффектом ограничений, связанных с физическим перемещением человека в период карантина, стала актуализация желания расширять «географические границы жизни». Начиная с желания путешествовать и заканчивая сменой места жительства. Вероятно, многие почувствовали важность физической среды для активной современной жизни и задумались над тем, где и как они живут, и где они хотели бы жить, чтобы похожие кризисные периоды было проще пережить.

«Я бы спланировала поездку в Черногорию, я бы хотела заранее туда переехать на этот период и там быть - там можно было очень долгое время выходить, гулять, возле моря быть, дышать, находиться на природе» [спортивный тренер, женщина, 32 года, Москва]

«Меньше всего сейчас на карантине людям хочется быть в Москве. Большинство мер абсурдны, над ними смеются. Все, у кого была возможность уехать в Подмосковье, в другой регион - уже там, а счастливчики улетели еще дальше» [руководитель компании, женщина, 34 года, Уфа] 


\section{НОВАЯ НОРМАЛЬНОСТЬ}

ОБРАЗ ЖИЗНИ, РЫНКИ, ИНФРАСТРУКТУРА

И КОММУНИКАЦИИ ПОСЛЕ ПАНДЕМИИ

\section{АВТОРЫ}

Т. А. Аймалетдинов

И. А. Гильдебрандт

Е. Н. Никишова

Д. С. Рассадина

\section{ОФОРМЛЕНИЕ}

Д. В. Басевич

\section{ИЗДАТЕЛЬСТВО НАФИ}

125047, г. Москва, улица 2-я Брестская, 30

Формат $210 \times 297$ мм.

Использованы гарнитуры:

Pragmatica, PragmaticaCTT, PragmaticaCondCTT 
ب

$\bullet \circ \circ$

ب

\section{0}

e $\bullet \circ \circ$ 